Historic, Archive Document

Do not assume content reflects current scientific knowledge, policies, or practices. 



\section{Kelsey's Hardy American Plants}

\section{and Specimen Evergreens}

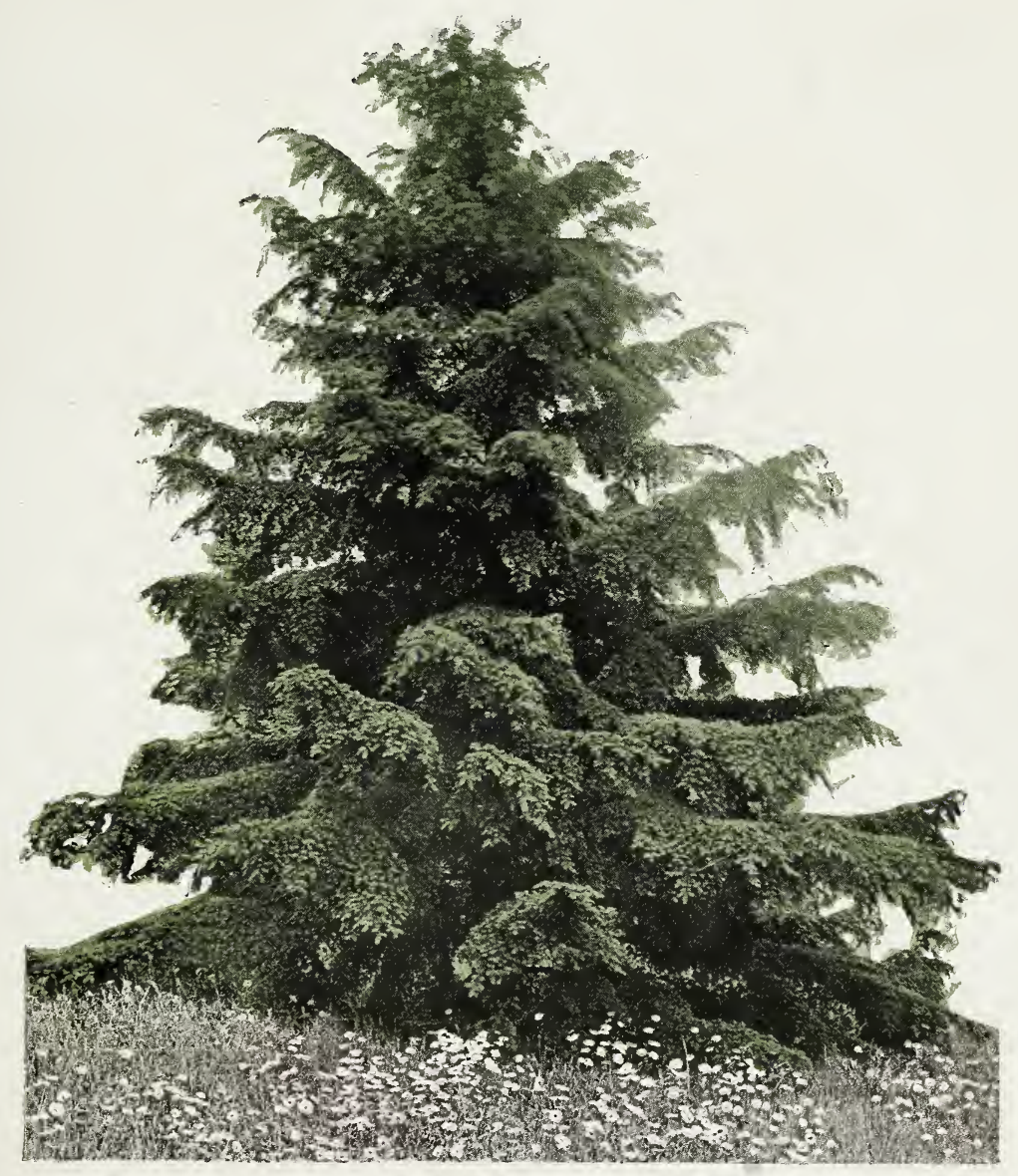

Foto by Harlan P. Kelsey at Arnold Arboretum

THE CAROLINA HEMLOCK (Tsuga caroliniana) Introduced to Horticulture by Harlan P. Kelsey

"Its dense dark foliage, sweeping semi-pendulous branches and eventually pyramidal form, combine to give a charm not found in any other evergreen known to cultivation." Full description and prices, see Page 13

HARLAN P. KELSEY, Owner, SALEM, MASSACHUSETTS BOXFORD - HIGHLANDS NURSERY, EAST BOXFORD, MASS. 


\section{Information to Buyers}

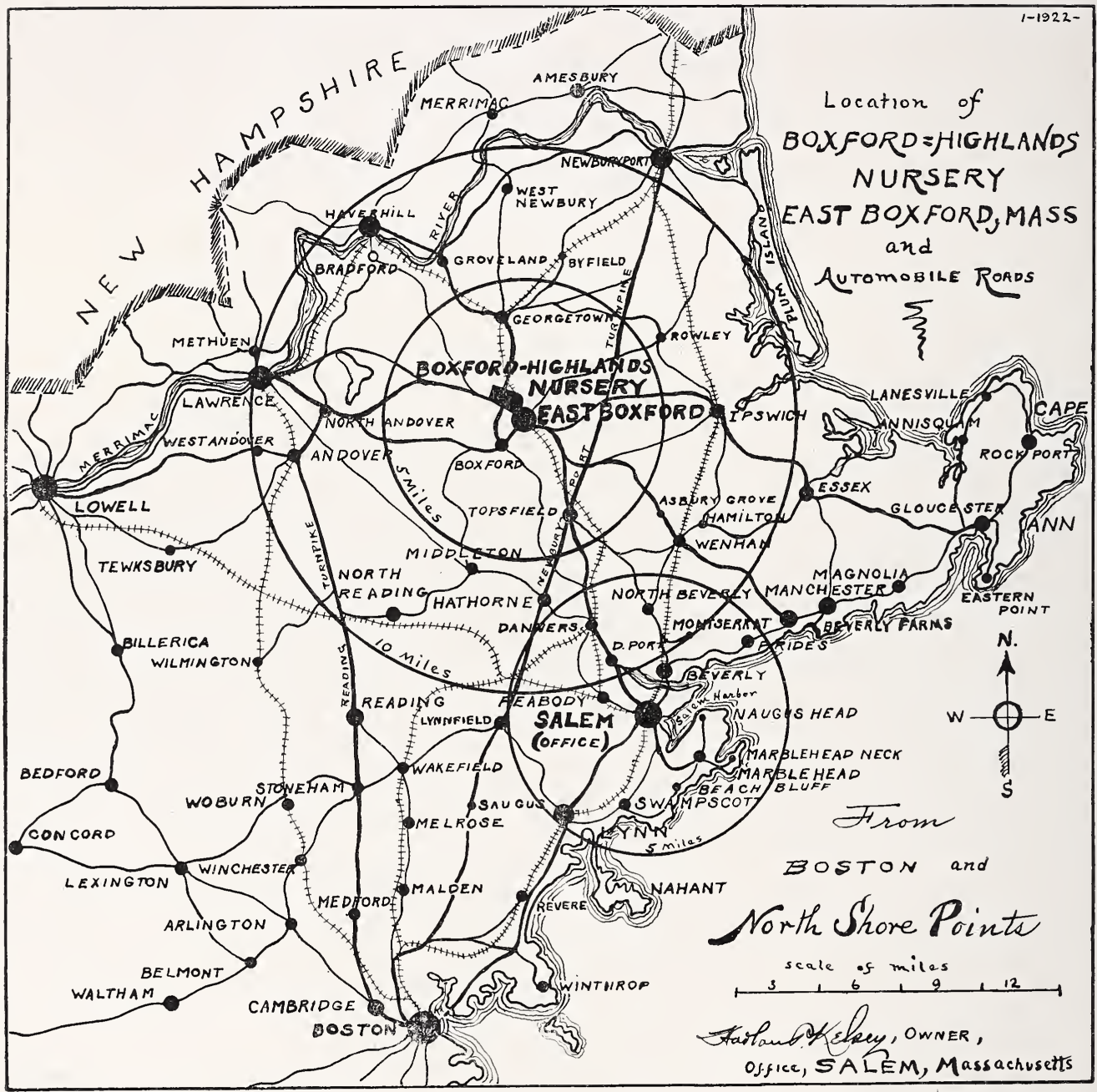

BOXFORD-HIGHLANDS NURSERY, EAST BOXFORD, MASSACHUSETTS, is located 28 miles north of Boston, at Boxford Station, Feorgetown Branch, B. \& M. R.R.

It is readily reached by good automobile roads from any part of New England. From Boston 28 miles, take either Newburyport Turnpike turning West at Topsfield, or Reading Turnpike turning East at North Andover. Other distances are Salem, 13 miles; Lawrence, 11 miles; Haverhill, 9 miles; Newburyport, 10 miles; Manchester, 13 miles; Ipswich, 9 miles; Lowell, 20 miles.

Hardy Native American Plants and Specimen Evergreens are my Specialties, backed by over thirty years' experience. Many of our choicest American ornamentals have been introduced to cultivation by me, including Carolina Hemlock, Azalea vaseyi, Rhododendron carolinianum, Lilium grayi, Shortia galacifolia, Robinia kelseyi and many others.

Shipping Season begins in Spring when frost leaves the ground, usually March 15th to June 1st. August planting of Specimen Evergreens - Rhododendrons, Kalmias, Leucothoes, Conifers and many Bulbs and Herbaceous Plants-has proved most successful, general stock going out again from September to December. 
Shipping Instructions should be given, otherwise I use my best judgment, but assume no risk. All shipments travel at purchaser's risk and carriers must be held liable for any damage in transit. All stock becomes the property of the purchaser on delivery to transportation company or carrier.

Delivery by Truck. Where the size of order warrants, there are distinct advantages in auto truck delivery for distances up to 30 to 50 miles and we have made large deliveries up to 200 miles. Stock arrives quickly and when wanted, and is delivered fresh on the grounds, saving local trucking and unpacking. Charges are made according to size of truck and distance traveled.

Prices are made to fit the quality of stock sent out. Discriminating buyers now realize that the greatest value of nursery stock is underground. Frequent transplanting and handling specimens with adequate, burlaped balls, mean success and quick results. It costs more, but it is the fixed policy of the Boxford-Highlands Nursery, and "cheap" stock-will_not be handled or sent out. The best is always the cheapest.

Special Selection. Stock specially selected at Nursery or ordered by mail will be charged at advance prices to fit the value of stock selected. The prices in this catalog cover the average good grade as they run in the nursery row.

Packing Charges. At prices printed in this catalog, Boxing, Balling or Burlaping is free except where noted. Where small sizes or deciduous stock is balled and burlaped by special request, a charge is always made to cover cost, as follows:

\section{Burlaping Charges:}

Each

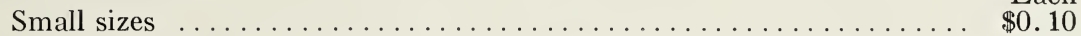

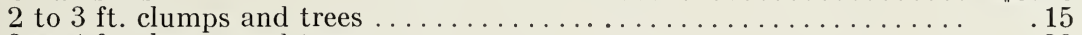

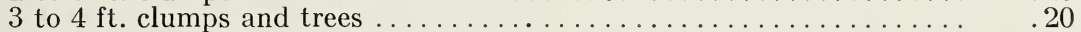

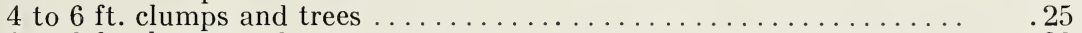

6 to $8 \mathrm{ft}$. clumps and trees ........................... 30

Larger sizes are billed in proportion. Where large evergreens are shipped

on "platforms," a suitable charge will be made to cover cost.

Terms. Cash or satisfactory reference from unknown customers. All accounts are due the first of each month, unless by special arrangement. Five at 10 rate; 50 at 100 rate; 500 at 1,000 rate.

Non-Warranty. No guarantee, express or implied, is made that stock will grow, whether planted by me or otherwise. Having no control over after treatment of plantings or over weather conditions, it is obvious that purchaser must assume all responsibility after stock leaves the Nursery in good condition. However, under certain conditions, I am prepared to guarantee plantings made by me covering a specified period, on an insurance basis. Charges will be made according to risk involved and value of material.

Claims for errors must be made on receipt of goods. If there is any mistake or fault on my part it will gladly be rectified.

Plant Names. Both the common names and the botanical or Latin names in this catalog conform to the Official Catalog of Standardized Plant Names, published by The American Joint Committee on Horticultural Nomenclature.

Landscape Forestry. We do Landscape Forestry, treating woodlands from a landscape standpoint as well as for commercial uses. Mr. Kelsey is open for consultations and engagements.

Quarantine. The Federal Horticultural Board has proclaimed a practically complete embargo on all Foreign Trees and Shrubs and most Herbaceous Plants. Americans will now learn that our Native Trees and Plants are hardier, freer from disease, more permanent, and far more beautiful and "fitting" in our landscapes and home grounds than exotic material. The best exotics can and now will be grown in America for Americans. We are growing them by thousands.

\section{HARLAN P. KELSEY}

\section{Boxford-Highlands Nursery . . . Salem, Massachusetts}




\title{
\begin{tabular}{llll}
\hline KELSEY'S HARDY AMERICAN PLANTS \\
\hline
\end{tabular}
}

\section{Landscape Department}

\author{
Planning and Planting, and the Use of Hardy Native Plants
}

The successful carrying out of any landscape improvement depends to so great an extent upon the knowledge, skill, and good taste of the one to whom this work is intrusted, that it is supremely important to start right, no matter whether the work be large or small.

By the employment of a trained landscape architect expensive experiments may be avoided and successful results insured. This applies to questions both of design and of practical planting.

There are so many well-trained landscape architects today that there is little excuse for anyone not having the joys that come from well-executed work that properly fits each case.

The undersigned takes charge of the laying out and planting of large and small grounds, extensive estates, parks, cemeteries, and other public or private landscape improvements. Particular attention is given to the use of hardy American plants, which are unquestionably the basis of all the best permanent plantings in this country, and particularly where naturalistic effects are desired. If this fact is ignored, the most finished and lasting results cannot be secured. The formal garden, where in the past exotics have been used almost exclusively, has wonderful possibilities for the employment of native plants, and especially our magnificent Rhododendrons, Kalmias, and other broadleaf evergreens, as well as Junipers, Hemlocks, Pines and other Conifers. These plants are not only absolutely hardy and unusually free from foreign diseases and pests, but show splendid summer and winter effects that can be produced in no other way. There are, in fact, no foreign plants which can adequately take their place.

Horticultural knowledge, including soil requirements and an intimate acquaintance with plant material, is quite as essential as and co-ordinate with proper designing, facts too often overlooked. Moreover, water-color sketches do not constitute landscape gardening. It is an art to be practised only after years of study and experience and, like painting and sculpture, must be born in one and cannot be altogether acquired.

We are not committed to the use of Native Plants exclusively, and, where useful and advisable, always introduce the best exotics to produce desired results.

The undersigned is prepared to make professional visits for consultation and advice, to make surveys, plans, and designs, and to undertake the entire construction, planting, and carrying out of landscape work of all descriptions.

The wild garden, the rockery, and the bog and water garden offer possibilities in the way of interest, distinctiveness, and variety that are often almost wholly overlooked or but meagerly taken advantage of.

The mountain or seashore bungalow, the modest town home, and the pretentious estate must each have a treatment suitable to particular needs, though in every case a development should prevail that makes the most of striking natural features or topography, giving to each a character of its own.

Lack of time, distance, and other conditions may sometimes lead customers to desire a local landscape architect. I know the leading members of the profession, and at any time on request will gladly recommend landscape architects who may be safely trusted with any commission, large or small.

Correspondence with those having new grounds to lay out and plant, or unsatisfactory old grounds to make over, is solicited. Charges are reasonable, yet sufficient to warrant the best results in fairness to my clients and myself.

Telephone Connection.

HARLAN P. KELSEY, Landscape Department Hawthorne Building, Salem, Massachusetts 
$\overline{H A R L A N ~ P . ~ K E L S E Y, ~ S A L E M, ~ M A S S A C H U S E T T S ~}$

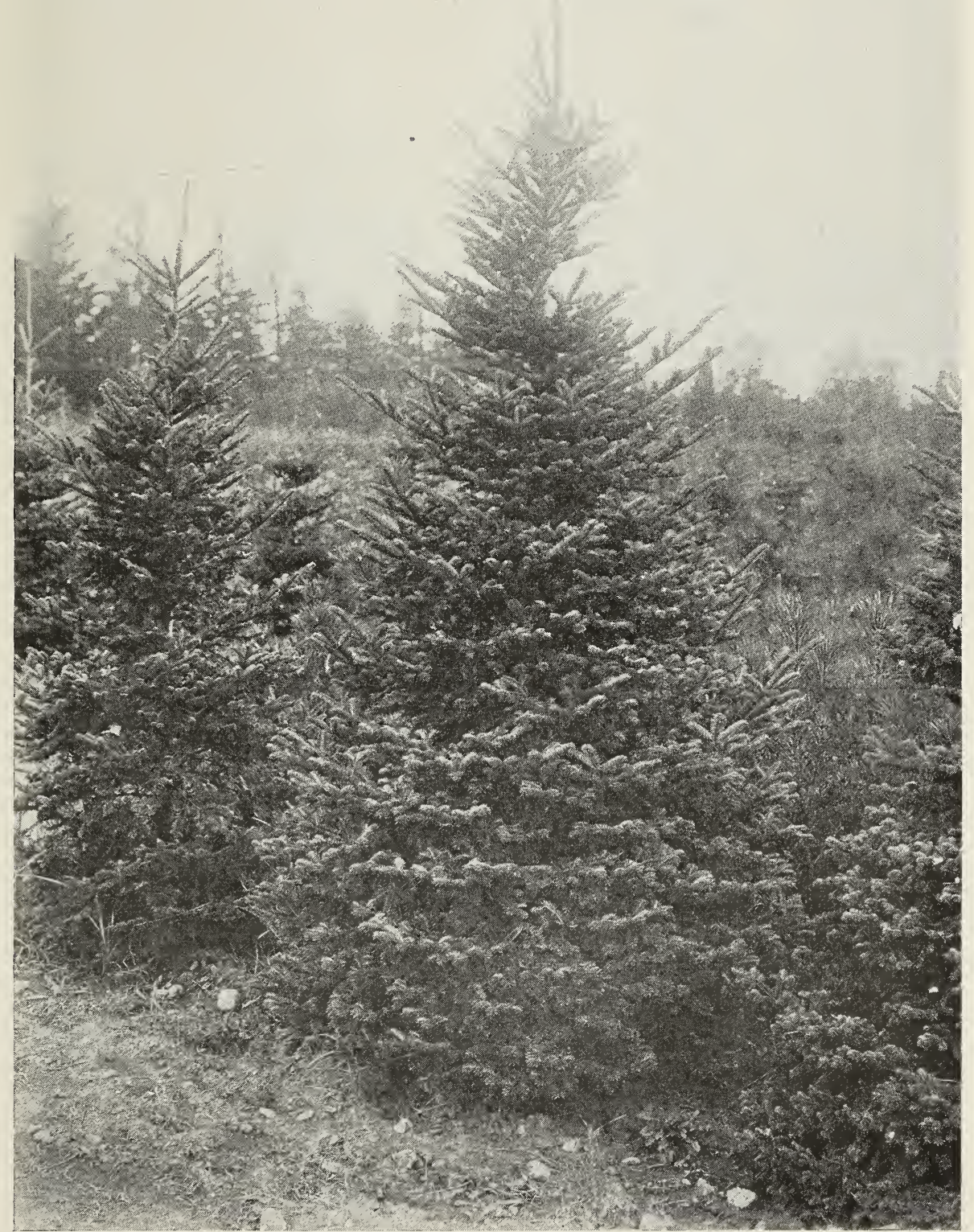

Specimen Fraser Fir at Boxford-Highlands Nursery

(Foto by H. P. K.) 


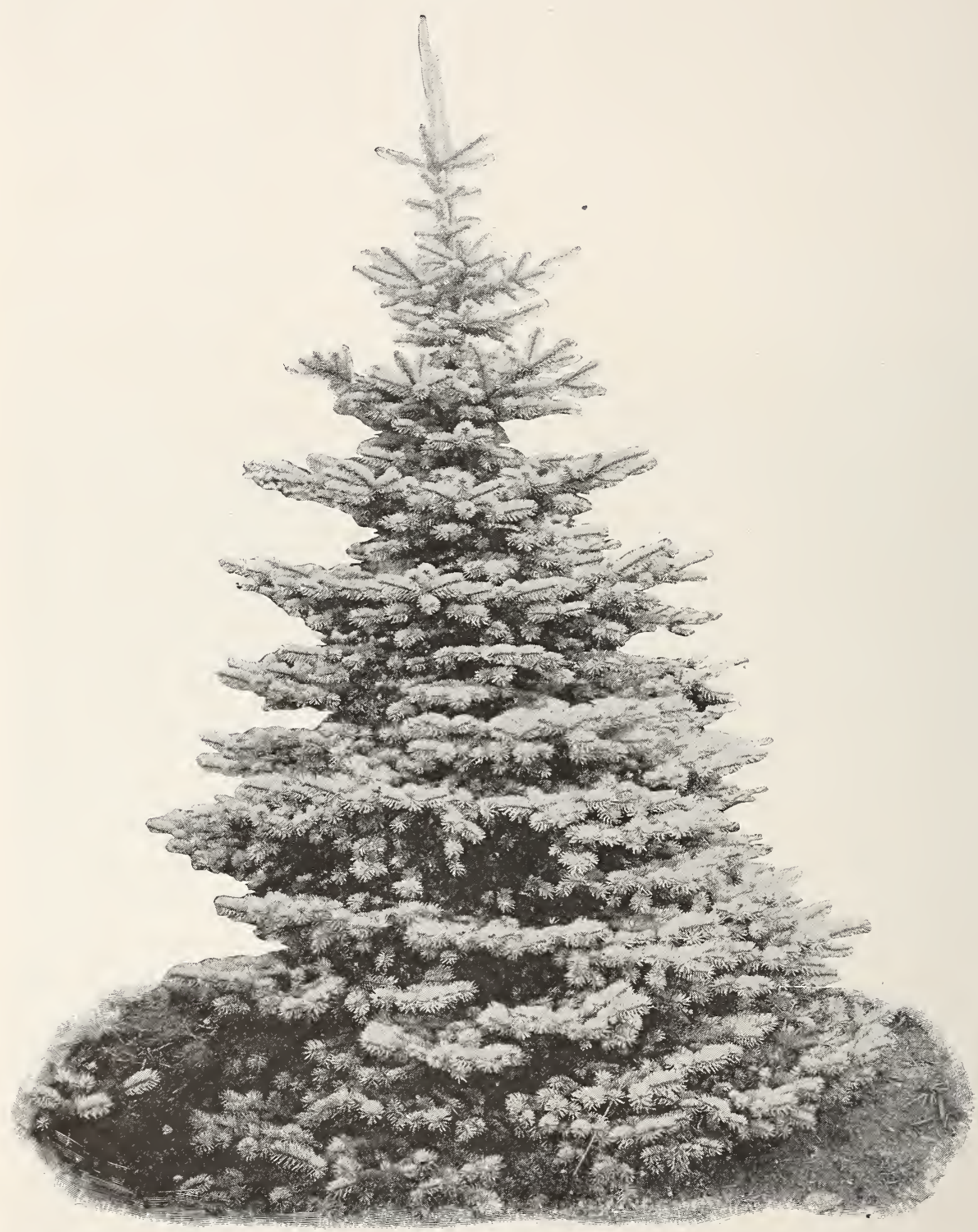

Specimen Koster Blue Spruce at Boxford-Highlands Nursery (Foto by H. P. K.) 


\section{KELSEY'S HARDY SPECIMEN EVERGREEN TREES AND SHRUBS}

\section{BOXFORD-HIGHLANDS NURSERY}

Note.- All Stock is nursery-grown and transplanted unless marked otherwise.

The larger sizes of Evergreens are always shipped with balls and burlaped.

Prices in this catalog cover the average good grade of plants as they run in the nursery row. Where special selection is made prices are increased accordingly.

The sizes immediately following the names indicate the hights attained by the Trees, Shrubs, and Plants in a wild state; under cultivation they usually 1 reach and often exceed the lesser hight given.

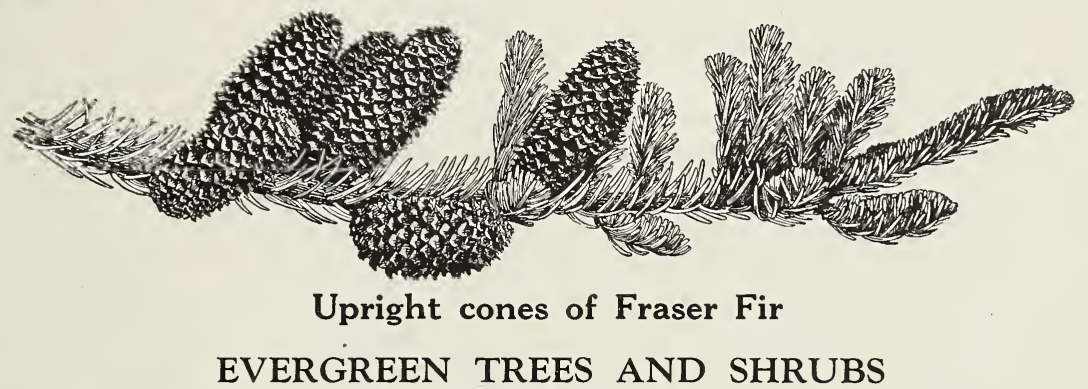

ABIES concolor, Concolor Fir. 80 to $250 \mathrm{ft}$. Foliage blue-green to blue-gray with broad needles, charming purple to yellow cones. A wonderfully beautiful, long-lived tree; rapid growth.

\begin{tabular}{|c|c|c|c|}
\hline & Each & 10 & 100 \\
\hline 2 to $18 \mathrm{in}$. &.$\$ 100$ & $\$ 800$ & $\$ 70$ \\
\hline & . 200 & 1800 & 1650 \\
\hline $3 \mathrm{ft}$. & 325 & 3000 & 2700 \\
\hline $\begin{array}{l}4 \mathrm{ft} . \\
5 \mathrm{ft} .\end{array}$ & $\ldots \ldots \ldots 450$ & & \\
\hline
\end{tabular}

fraseri, FRASER FIR. 30 to $70 \mathrm{ft}$.

Dark-green, thickest foliage, blue underneath; compact, pyramidal habit. One of our choicest evergreens especially for New England shore planting. The only permanent "Balsam Fir." Thousands of perfect specimens up to 16 feet. This is a specialty at Boxford-Highlands Nursery, and we can supply in car lots for mass planting or to the Nursery Trade. This fine species comes from the high Carolina Mountains. There are few Evergreens we can recommend so highly.

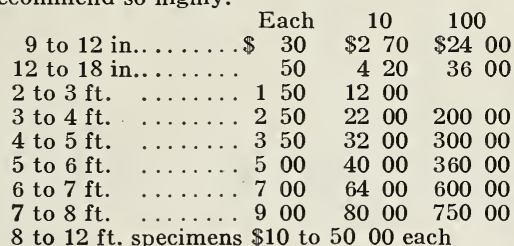

homolepis (brachyphylla), Nikko FiR. 80 to $100 \mathrm{ft}$.

Very distinctive rare Fir, horizontal branches, dark glossy foliage; green leaves, silvery white underneath, and violet purple cones. Very hardy Japanese species.

$$
\text { Each } 10
$$

12 to 18 in....... $\$ 200 \quad \$ 1800$

18 to 24 in......... $300 \quad 2800$
ABIES homolepis umbilicata (umbellata), DIMPLECONE Fir. 50 to $80 \mathrm{ft}$.

Variety with green cones, with lighter colored leaves.

5 to $12 \mathrm{ft}$. specimens $\$ 7$ to 2000 each pectinata, European Silver Fir. 100 to $200 \mathrm{ft}$. Rapid, open growing sort with glossy green needles, silvery beneath.

$$
12 \text { to } 18 \text { in...... Each } \quad 10 \text { \$3 } 00 \quad \$ 2700
$$

veitchi, VEITCH FIR. 80 to $100 \mathrm{ft}$.

Strong-growing, ironclad Fir, making a most striking lawn specimen or in groups. Bright green foliage, silver-blue underneath. A rare

\begin{tabular}{|c|c|c|}
\hline & & \\
\hline & Each & 10 \\
\hline 12 to 18 in.. & $\ldots \ldots \$ 260$ & $\$ 2400$ \\
\hline $\begin{array}{l}8 \text { to } 24 \mathrm{in} \text {.. } \\
\text { to } 3 \mathrm{ft} \text {. }\end{array}$ & . 400 & $\begin{array}{l}3600 \\
5400\end{array}$ \\
\hline & $\ldots \ldots 800$ & \\
\hline
\end{tabular}
conifer from Japan and Manchuria.

ANDROMEDA polifolia, see under Rhododendrons and Other Broadleaf Evergreens.

ARCTOSTAPHYLOS uvaursi, see under Rhododendrons, etc.

CHAMAECYPARIS obtusa, HINOKI CYPRESS. 80 to $120 \mathrm{ft}$.

Graceful tree with "Japanese" effect; bright green foliage. Fine also for low-clipped hedge; $\begin{array}{llll}\text { brown cones. } & \text { Each } & 10 & 100\end{array}$

9 to 12 in.......\$ $75 \quad \$ 600 \quad \$ 5000$

12 to 18 in......... $150 \quad 1200 \quad 9000$

18 to 24 in....... $200 \quad 1800$

Horticultural variety of Chamaecyparis. DWARF Hinoki Cypress (obtusa nana). 4 to $10 \mathrm{ft}$.

Very dwarf Japanese Evergreen; picturesque effect. Dark-green, shiny foliage, densely tufted.

12 to 18 in.......\$3 00 each

CHAMAEDAPHNE calyculata, see Rhododendrons and Other Broadleaf Evergreens.

DAPHNE cneorum, see Rhododendrons and Other Broadleaf Evergreens. 


\begin{tabular}{llll}
\hline KELSEY'S HARDY AMERICAN PLANTS \\
\hline
\end{tabular}

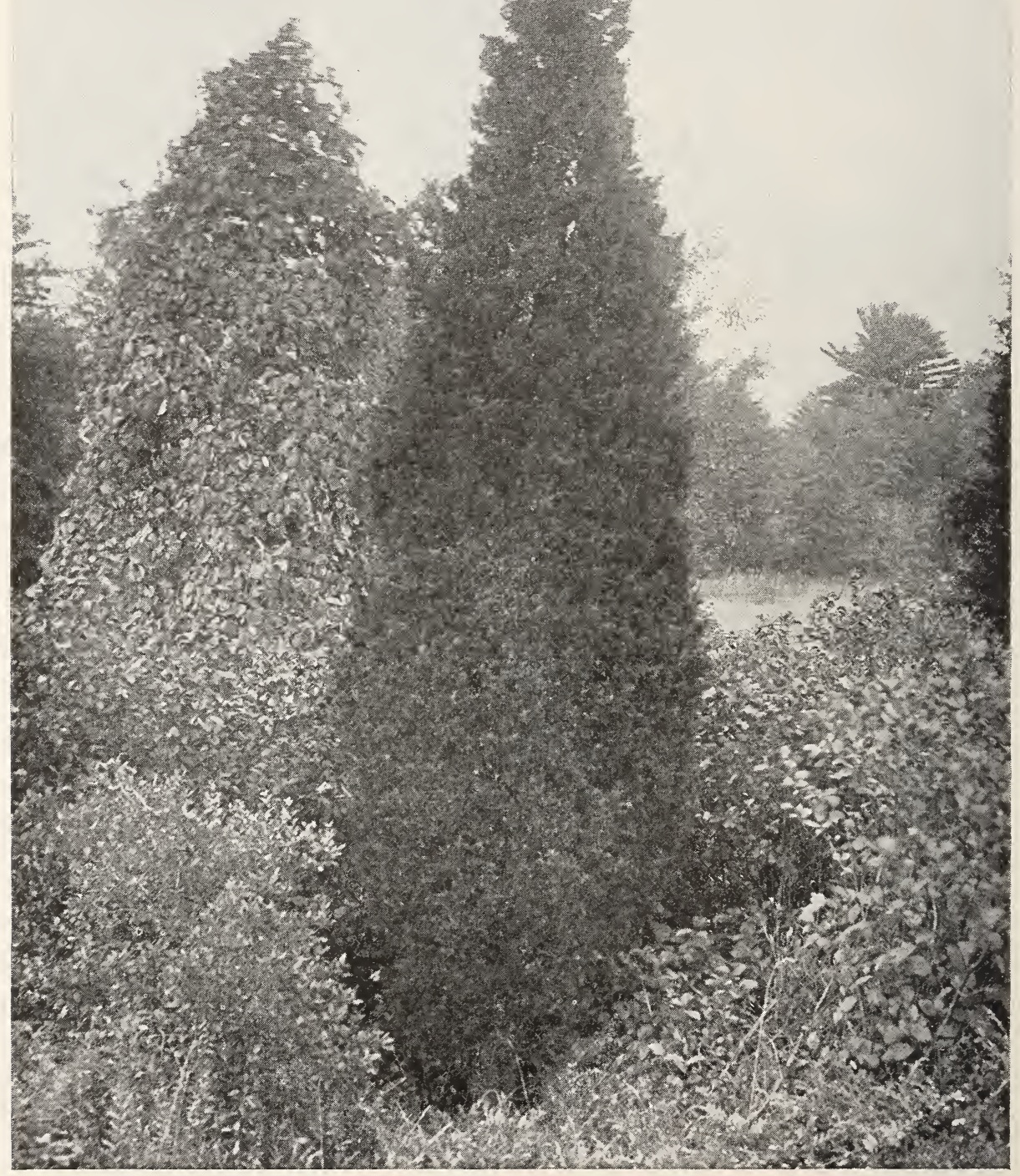

Red-cedar (Juniperus virginiana) specimen as grown at Boxford-Highlands Nursery

(Fotoby H. P. K.) 
JUNIPERUS communis depressa, PROSTRATE JUNIPER. 1 to $4 \mathrm{ft}$.

The best Juniper for ground cover. Forms vary from completely "prostrate" to the "ascending" bushy types. It is at home on sandy or gravelly hillsides in full sun exposure, or in quite dense shade. Single plants will often reach a diameter of 15 feet or more. It is the hardy type that gives such charm to New England hillsides. Often a beautiful bronze in autumn and winter, and studded with bright blue fruit. Invaluable for landscape plantings.

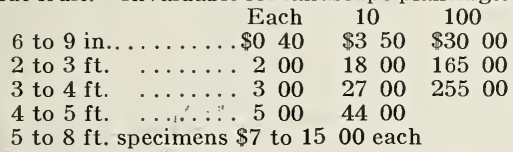

sabina, SAvin. 4 to $10 \mathrm{ft}$.

Semi-erect dwarf, very bushy; fine among rocks and boulders and for borders.

$$
6 \text { to } 9 \text { in........ } \begin{array}{cc}
\text { Each } & 10 \\
\$ 1200 & \$ 1200
\end{array}
$$

scopulorum, Colorado Juniper. 20 to $40 \mathrm{ft}$. Rocky Mountain species allied to Juniperus virginiana. Foliage often bluish tinge.

$$
9 \text { to } 12 \text { in....... } \$ 100 \quad \$ 800
$$

virginiana, $R$ ED-CEDAR. 40 to $100 \mathrm{ft}$.

Pyramidal habit; dark-green to bluish foliage, with many variable forms. This is one of the most useful and characteristic trees of our native landscape. It rivals the Italian Cypress in beauty, is absolutely hardy, and stands sea exposure well. Fruit dark-blue and conspicuous, hanging until mid-winter. For many effects it is the most useful evergreen for northern latitudes. This is a specialty at Boxford-Highlands Nursery, and we can supply specimens up to 30 feet. We have made many notable plantings of large Cedars with uniform success. $\quad$ Each $10 \quad 100$

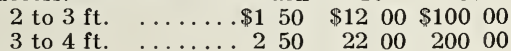

$\begin{array}{llll}3 \text { to } 4 \mathrm{ft} . & \ldots \ldots \ldots & 250 & 2200 \\ 4 \text { to } 5 \mathrm{ft} . & \ldots \ldots \ldots & 350 & 3000\end{array}$

5 to $6 \mathrm{ft} . \ldots \ldots \ldots 500 \quad 4000$

6 to $7 \mathrm{ft} . \quad \ldots \cdots \cdots 700 \quad 6400$

7 to $8 \mathrm{ft} . \ldots \ldots 1000 \quad 9000$

8 to $9 \mathrm{ft}$. .......12 $50 \quad 11200$

9 to $10 \mathrm{ft}$. ........18 $00 \quad 16000$

10 to $20 \mathrm{ft}$. specimens $\$ 20$ to 15000 each

Horticultural varietics of Juniperus.

PFITZER Juniper (chinensis pfitzeriana). 4 to $8 \mathrm{ft}$. One of our choicest and hardiest dwarf "spreading" evergreens of the "feathery spray" type.

$\begin{array}{rr}\text { Each } & 10 \\ 15 \text { to } 18 \text { in....... } \$ 350 & \$ 3000 \\ 18 \text { to } 24 \text { in...... } 500 & 4500\end{array}$

Schot ReD-cedar (virginiana schotti). 15 to $30 \mathrm{ft}$.

A dwarfer dense pyramidal form of Red-cedar with bright green foliage.

$$
\begin{aligned}
& 4 \text { to } 5 \mathrm{ft} . \quad \ldots \ldots \ldots \$ 450 \\
& 5 \text { to } 6 \mathrm{ft} .
\end{aligned}
$$

Silver Red Cedar (virginiana glauca). 40 to $60 \mathrm{ft}$.

Striking type with blue-green foliage.

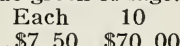

5 to $6 \mathrm{ft} . \ldots \ldots \ldots 750 \quad \$ 7000$

Tamarix Savin (sabina tamariscifolia). 1 to $4 \mathrm{ft}$.

Trailing species with feathery gray "sprays" of foliage. A beautiful rockery plant and for edgings. Each 10

12 to 15 in.......\$3 $00 \quad \$ 2700$
KALMIA, see Rhododendrons and Other Broadleaf Evergreens.

LEIOPHYLLUM buxifolium, see Rhododendrons and Other Broadleaf Evergreens.

LE UCOTHOE catesbaei, see Rhododendrons and Other Broadleaf Evergreens.

PICEA canadensis $(a l b a)$, White Spruce. 60 to $70 \mathrm{ft}$.

Compact pyramidal growth, with aromatic silver-gray foliage. For seashore planting it is unexcelled, and for northern latitudes is highly recommended for single lawn specimen, massing or for forest; glossy light brown cones.

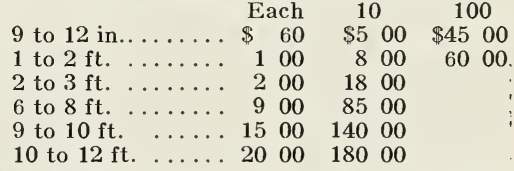

\begin{tabular}{|c|c|c|}
\hline Each & 10 & 100 \\
\hline 12 to $18 \mathrm{in} \ldots \ldots \ldots . \$ 100$ & $\$ 800$ & $\$ 6000$ \\
\hline 18 to 24 in....... 150 & 1200 & 10000 \\
\hline
\end{tabular}

engelmanni, ENGELMANn SPRUCE. 75 to $150 \mathrm{ft}$. Rocky Mountain evergreen with narrowpyramidal form of great beauty. Flowers bright purple, cones light brown. excelsa, Norway Spruce. 75 to $150 \mathrm{ft}$.

This well-known spruce varies greatly in type,

\begin{tabular}{|c|c|c|c|}
\hline & Each & 10 & 100 \\
\hline 12 to 18 in.... & $\$ 50$ & $\$ 400$ & $\$ 3600$ \\
\hline 18 to 24 in... & 75 & 600 & 5400 \\
\hline 2 to $3 \mathrm{ft}$. & 150 & 1200 & 11000 \\
\hline 3 to $4 \mathrm{ft}$. & 250 & 2200 & \\
\hline 4 to $5 \mathrm{ft}$. & 400 & 3600 & \\
\hline
\end{tabular}
some with very picturesque pendulous branches and others again of upright growth. A most beautiful conifer, especially where not crowded. Flowers bright purple and light brown cones.

koyamai. 20 to $30 \mathrm{ft}$.

Branchlets bright reddish-brown, leaves bluishwhite above and light brownish-green cones. A rare Central Japanese species.

Each $10 \quad 100$

$\begin{array}{lllll}3 & \text { to } 6 \text { in.......... } \$ 30 \quad \$ 2 & 00 & \$ 18 & 00\end{array}$ omorika, Servian Spruce. 80 to $100 \mathrm{ft}$.

Rare and very beautiful. Needles are unusual with conspicuous white marking. One of the most charming conifers as grown in Arnold Arboretum; purple flowers and glossy cinnamon brown cones.

7 to $8 \mathrm{ft}$. .....\$20 00 each

orientalis, Oriental Spruce. 80 to $120 \mathrm{ft}$. A graceful spruce, with wide, roundish pyramidal form of slow growth. Much used in Japanese gardens; carmine flowers.

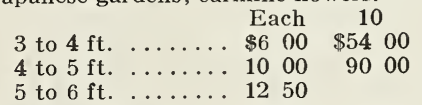

pungens (parryana), Colorado Spruce. 80 to $150 \mathrm{ft}$.

Extremely hardy and well known for its peculiar horizontal whorls of branches and stiff needles. Stands salt air well. Cones light brown, glossy.

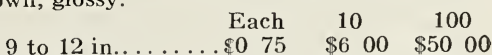

12 to 18 in......... $100 \quad 8 \quad 800 \quad 7000$

18 to 24 in......... $150 \quad 1200 \quad 9000$

2 to $3 \mathrm{ft} . \ldots \ldots \ldots 250 \quad 2200$

3 to $4 \mathrm{ft} . \ldots \ldots \ldots .400 \quad 3600$

4 to $5 \mathrm{ft} . \ldots \ldots \ldots 500 \quad 4400$

5 to $6 \mathrm{ft} . \ldots \ldots \ldots 700 \quad 6400$

6 to $7 \mathrm{ft} . \ldots \ldots \ldots 900 \quad 8000$

7 to $15 \mathrm{ft}$. specimens $\$ 10$ to 5000 each 


\section{KELSEY'S HARDY AMERICAN PLANTS}

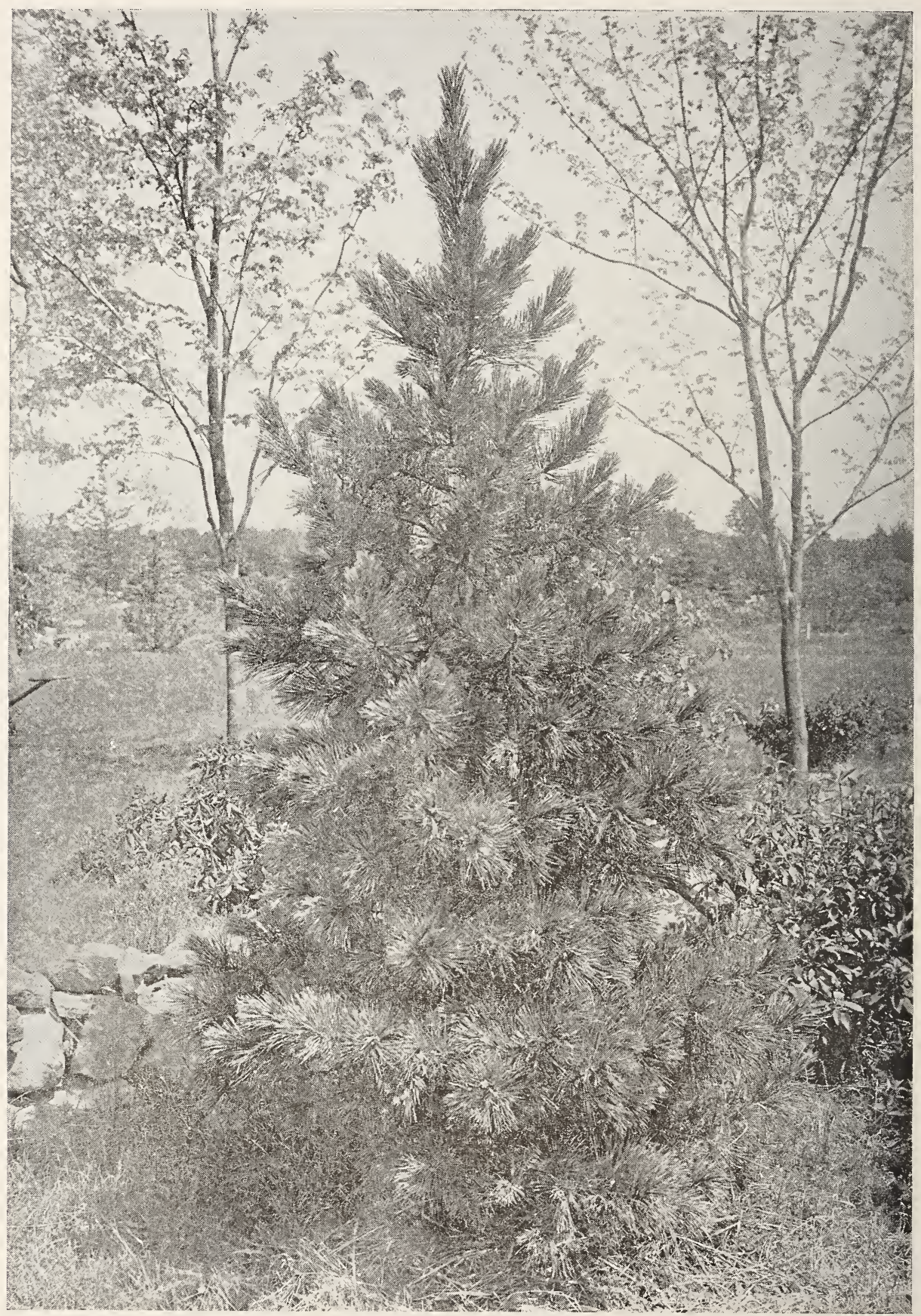

(Fotoby H. P.K.) Swiss Stone Pine (Pinus cembra) specimen at Boxford-Highlands Nursery 


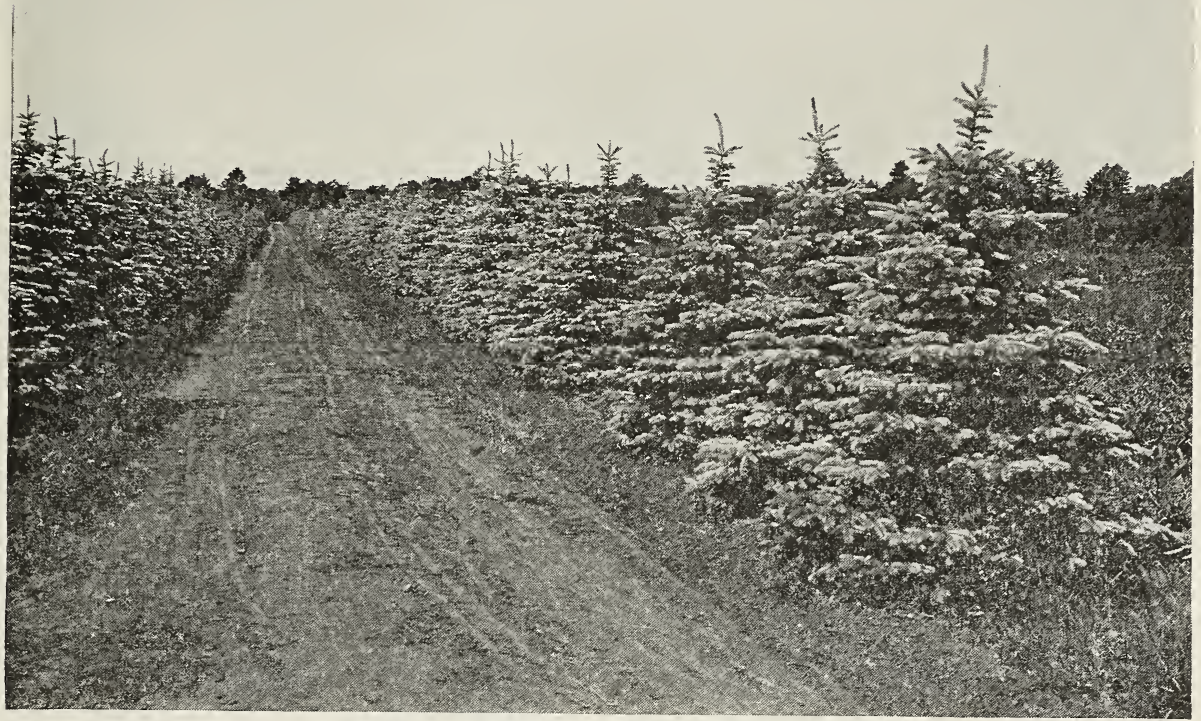

(Foto by H. P. K.)

Avenue of specimen Koster Blue Spruces at Boxford-Highlands Nursery

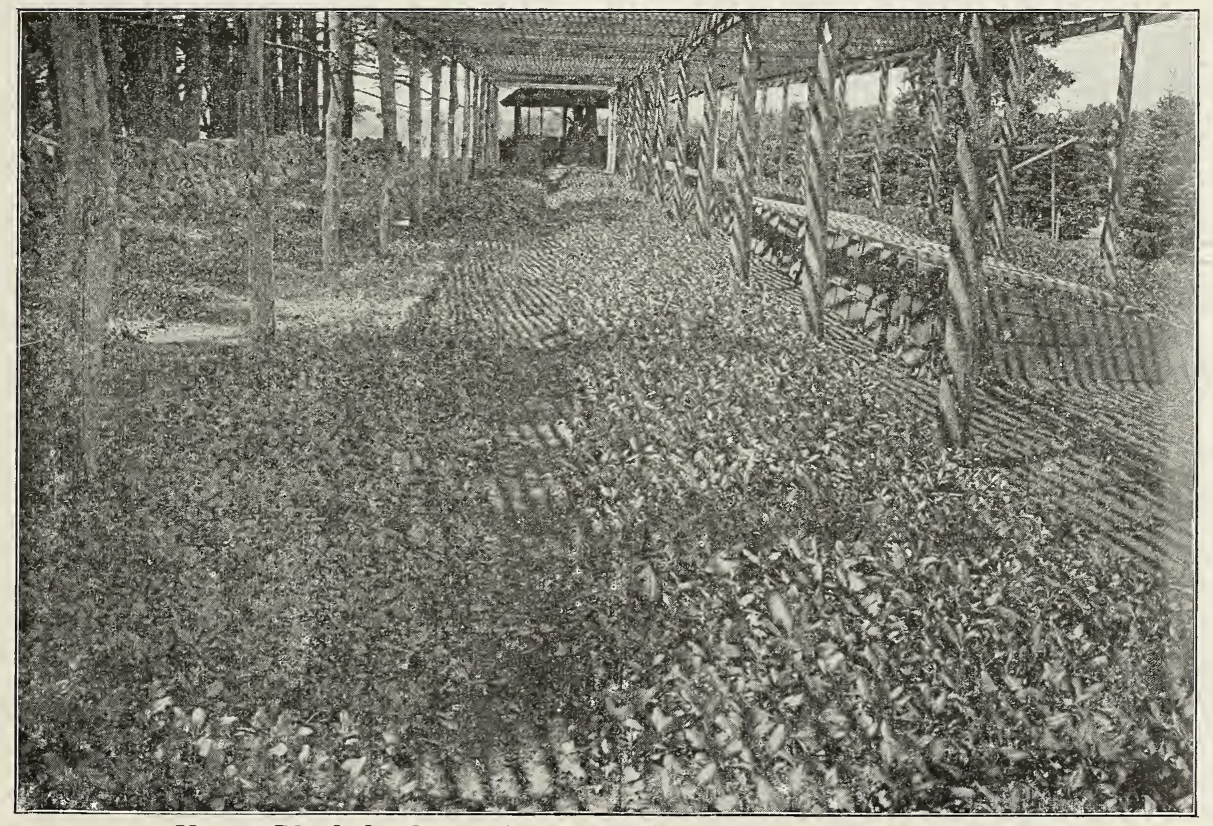

Young Rhododendrons, Azaleas and Mountain Laurel grown by tens of thousands at Boxford-Highlands Nursery 


\section{\begin{tabular}{llll}
\hline KELSEY'S HARDY AMERICAN PLANTS \\
\hline
\end{tabular}}

Hort. var. of Picea, SPRUCE.

Blue Colorado Spruce (pungens glauca). 80 to $100 \mathrm{ft}$.

Blue form, very conspicuous.

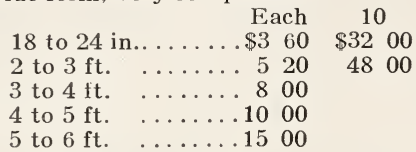

Koster Blue Spruce (pungens kosteri.) 50 to $80 \mathrm{ft}$.

Variety with brilliant blue foliage. Propagated by grafting on the green type. Our stock is strictly true to original. At BoxfordHighlands Nursery may be seen hundreds of perfect specimens from 6 to $10 \mathrm{ft}$. in hight. Probably the finest lot in any nursery.

$$
\text { Each } 10
$$

2 to $3 \mathrm{ft} . \ldots \ldots \ldots \$ 00 \quad \$ 5600$

3 to $4 \mathrm{ft} . \ldots \ldots \ldots 900 \quad 8000$

5 to $6 \mathrm{ft} . \ldots \ldots \ldots 2500 \quad 23600$

6 to $7 \mathrm{ft}$. ........ $3500 \quad 32500$

7 to $10 \mathrm{ft}$. specimens $\$ 40$ to 7000 each

PIERIS floribunda, see Rhododendrons and Other Broadleaf Evergreens.

PINUS austriaca, see Hort. var. AUStrian Pine. banksiana, J ACK PINE. 50 to $70 \mathrm{ft}$.

Quick grower and easy to transplant. Fine ornamental and very useful for reclaiming

"abandoned" or poor soils. Pale yellow brown cones.

\begin{tabular}{|c|c|c|c|}
\hline & Each & 10 & 100 \\
\hline 2 to $3 \mathrm{ft}$. & $\ldots \ldots \ldots \$ 60$ & $\$ 400$ & $\$ 3000$ \\
\hline 3 to $4 \mathrm{ft}$. & $\ldots .125$ & 800 & 6000 \\
\hline 4 to $6 \mathrm{ft}$. & $\ldots 200$ & 1600 & 12000 \\
\hline 6 to $8 \mathrm{ft}$. & 400 & 3600 & \\
\hline 8 to $10 \mathrm{ft}$. & $\ldots \ldots \ldots 700$ & 6400 & \\
\hline
\end{tabular}

10 to $16 \mathrm{ft}$. specimens $\$ 10$ to 2500 each

cembra, Swiss Stone Pine. 50 to $70 \mathrm{ft}$.

A "dwarf White Pine." This charming species cannot be too highly recommended for rockeries or hillsides, or where space is limited and one wishes to have the soft feathery foliage effect of the beautiful common but large-growing White Pine. We have hundreds of beautiful specimens - narrow, dense pyramids. In cultivation rarely over 20 feet.

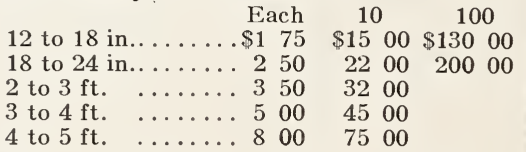

densiflora, JAPANESE RED Pine. 80 to $100 \mathrm{ft}$. Hardy and of distinctive habit. Very free from diseases and insects, and one of the coming Pines for landscape work and woodlands. A fine stock.

$\begin{array}{llll}3 \text { to } 4 \mathrm{ft} & \text { Each } & 10 & 100\end{array}$

$\begin{array}{lllll}4 & & & 100 & \end{array}$

6 to $9 \mathrm{ft}$. specimens $\$ 8$ to 1500 each

flexilis, Limber Pine. 50 to $80 \mathrm{ft}$.

Of the "White Pine section," from the Rocky Mountains. Picturesque dwarf habit, silver foliage, and especially choice for the rocky hillside and in small Pinetums. In cultivation, of fairly slow growth, large light brown cones.

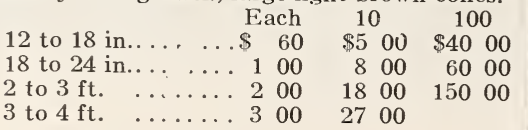

PINUS montana, Swiss Mountain Pine. Variable from 8 to $40 \mathrm{ft}$.

A "bush" dwarf Pine, with dark-green foliage. Rarely attains 10 to 12 feet, diameter equaling hight. Invaluable.

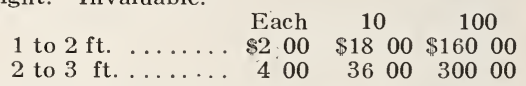

monticola, Western White Pine. 100 to 150 ft.

Pyramidal form with slender somewhat pendulous branches.
9 to 12 in...... Each
10
12 to 18 in....... 125
1000

parviflora, Japanese White Pine. 50 to $80 \mathrm{ft}$. Hardy and very ornamental Japanese Pine bearing numerous decorative cones when older.

9 to 12 in....... $\$ 100$ each

pentaphylla

Probably a form of Pinus parviflora. Each 10

3 to 6 in......... \$50 \$4 00

ponderosa, Western Yellow Pine. 100 to $230 \mathrm{ft}$.

This Western species is extremely hardy, with striking dark-green, long needles. Fine for forestry planting or as a specimen.

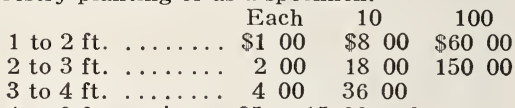

4 to $9 \mathrm{ft}$. specimens $\$ 5$ to 1500 each

pungens, Table Mountain Pine. 30 to $60 \mathrm{ft}$. From the Southern Alleghanies. Spined cones remain on tree indefinitely, giving a curious and picturesque effect. The growth is quite "Japanesy."

6 to $10 \mathrm{ft}$. specimens $\$ 5$ to 1600 each

resinosa, RED PINE. 60 to $150 \mathrm{ft}$.

One of our most valuable native Pines, for ornamental or forestry purposes. Long, lustrous green needles, densely tufted. Considered by many even superior to the Austrian Pine. Incorrectly called "Norway" Pine.

$\begin{array}{llll} & \text { Each } 10 & 100\end{array}$

2 to $3 \mathrm{ft} . \ldots \ldots \ldots . \$ 175 \quad \$ 1600 \quad \$ 14000$

3 to $4 \mathrm{ft} . \ldots \ldots \ldots 2 \quad 2 \quad 50 \quad 20 \quad 00 \quad 18000$

4 to $5 \mathrm{ft} . \cdots \cdots \ldots .500 \quad 5000 \quad 36000$

6 to $8 \mathrm{ft}$. specimens $\$ 8$ to 1200 each

rigida, Pitch Pine. 40 to $80 \mathrm{ft}$.

The common Pine of our New England hillsides - very picturesque.

\begin{tabular}{|c|c|c|}
\hline & Each & 10 \\
\hline $\begin{array}{l}\text { to } 6 \mathrm{ft} . \\
\text { to } 8 \mathrm{ft} .\end{array} \ldots$ & $\begin{array}{r}\$ 400 \\
600\end{array}$ & $\begin{array}{rl}\$ 3600 \\
50 & 00\end{array}$ \\
\hline
\end{tabular}

8 to $10 \mathrm{ft} . \ldots \ldots 1000 \quad 8000$

strobus, White Pine. 80 to $150 \mathrm{ft}$.

This native Pine is easily the king of American conifers, both as an ornamental and as a forestry tree. We have thousands of specimens up to 12 feet. Special prices on large quantities for park or forestry purposes.

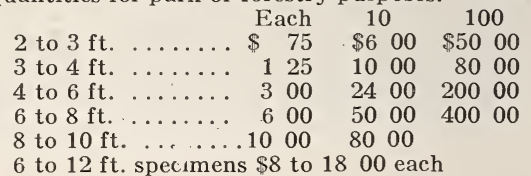




\section{$\overline{H A R L A N ~ P . K E L S E Y, ~ S A L E M, ~ M A S S A C H U S E T T S ~}$}

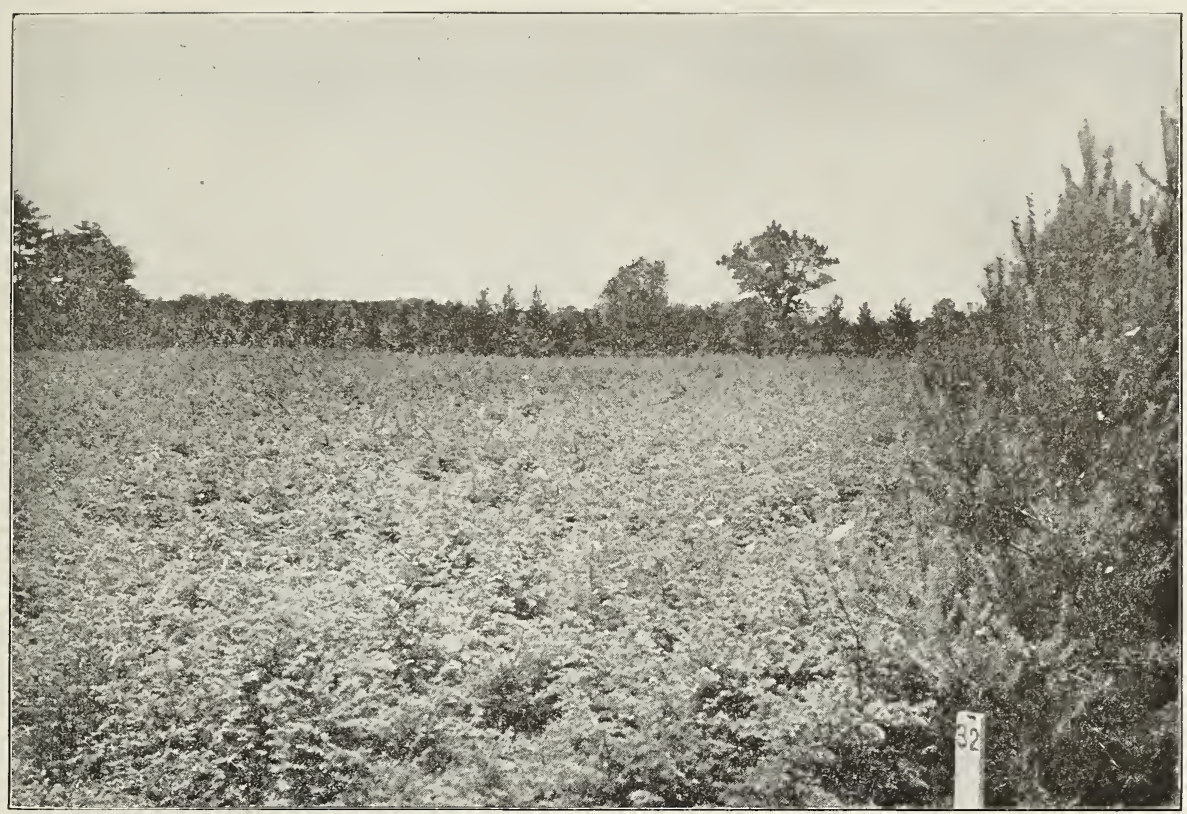

Solid block of 10,000 young Carolina Hemlocks at Boxford-Highlands Nursery

(Foto by H. P. K.)

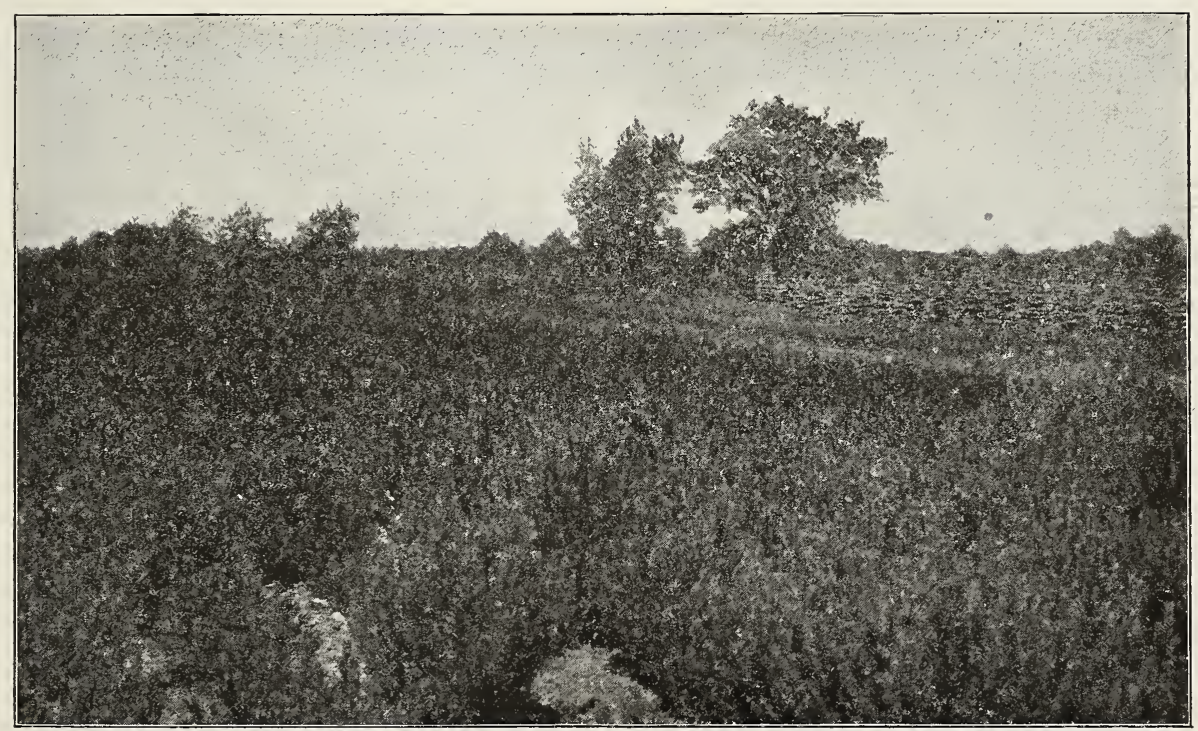

Block of Pinus mughus specimens at Boxford-Highlands Nursery

(Foto by H. P. K.) 
PINUS sylvestris, Scotch Pine. 50 to $120 \mathrm{ft}$. Of rapid growth, with attractive reddish bark and bright green foliage of bluish tinge. A very popular variety much used in securing immediate effects. Boxford-Highlands Nursery has an unusually fine stock up to $16 \mathrm{ft}$.

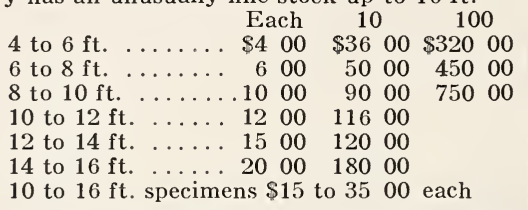

thunbergi, JAPANESE Black Pine. 80 to 120 ft.

A very distinctive species with handsome, broad pyramidal head and orange-yellow branchlets. Perfectly hardy.

\begin{tabular}{|c|c|c|c|}
\hline 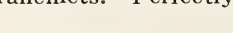 & Each & 10 & 100 \\
\hline 18 to 24 in & $\$ 125$ & $\$ 1000$ & $\$ 90 \quad 00$ \\
\hline 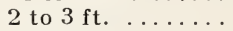 & 200 & 1800 & 16500 \\
\hline ft. & 275 & 2400 & 220 \\
\hline to 5 & 35 & 3000 & \\
\hline
\end{tabular}

Hort. var. of Pines.

AUstrian Pine (nigra austriaca), 80 to $150 \mathrm{ft}$. Of the "Black Pine" group, and one of the most beautiful ornamental conifers. Rapid growth and stately habit, the dark-green foliage densely covering the branches. $\Lambda$ fine stock of specimen trees.

\begin{tabular}{|c|c|c|c|}
\hline & Each & 10 & 100 \\
\hline 18 to 24 in &.$\$ 125$ & $\$ 1200$ & $\$ 10000$ \\
\hline - & . 175 & 1600 & 13000 \\
\hline 3 & 300 & 2800 & 25000 \\
\hline $5 \mathrm{ft}$ & 450 & 4200 & \\
\hline
\end{tabular}

$$
4 \text { to } 5 \mathrm{ft} \text {. ....... } 450 \quad 4200
$$

Mugho Pine (montana mughus).

Usually shrubby and prostrate. The most useful dwarf Pine for rockeries, ground-cover, and positions where a low-spreading, darkgreen effect is needed. Boxford-Highlands Nursery has thousands of specimens from a few inches to several feet in diameter. The Mugho Pine cannot be too highly recommended. $\begin{array}{rrrr}6 \text { Each } & 10 & 100 \\ \text { to } 12 \text { in....... } \$ 100 & \$ 800 & \$ 7000\end{array}$ 12 to 18 in........ $125 \quad 1000 \quad 9000$ 18 to 24 in........2 $00 \quad 1800 \quad 15000$ 2 to $3 \mathrm{ft} . \ldots \ldots \ldots 400 \quad 3600 \quad 30000$ 3 to $4 \mathrm{ft}$....... $700 \quad 6400$

Extra specimens $\$ 8$ to 1200 each

PSEUDOTSUGA douglasi, Douglas Fir. 80 to $200 \mathrm{ft}$.

This is one of our most beautiful Rocky Mountain Firs. Very rapid in growth. Soft, lively green foliage, dense habit and in the Northwest becoming a giant forest tree. The staminate catkins are orange, and pistillate catkins reddish and quite ornamental.

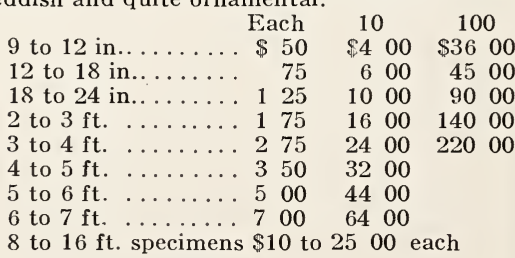

Hort. var. of P. douglasi.

Blue Douglas Fir (douglasi glauca).

Form with silvery-blue foliage. More compact habit and with smaller cones.

$$
18 \text { to } 24 \text { in....... Each } \quad 100
$$$$
3 \text { to } 4 \mathrm{ft}
$$

\section{RHODODENDRONS, see p. 15}

TAXUS canadensis (minor), Canada Yew. 1 to $3 \mathrm{ft}$.

Hardy ground cover, invaluable for the open or in shade. Bright red berries. In autumn

\begin{tabular}{|c|c|c|c|}
\hline & Each & 10 & 100 \\
\hline 6 to 9 in.. & $\$ 75$ & $\$ 700$ & $\$ 6000$ \\
\hline 9 to 12 in.. & 100 & 900 & 8000 \\
\hline $15 \mathrm{in}$ & 150 & 1200 & 11500 \\
\hline
\end{tabular}
the foliage turns a rich bronze where exposed to the sun.

cuspidata, JAPANESE YEW. 30 to $50 \mathrm{ft}$.

The only strictly hardy, upright growing Yew for the North. Very dark-green foliage.

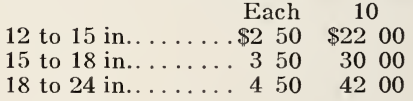

Hort. var. of Taxus.

DWARF JAPANESE YEW (cuspidata brevifolia). 3 to $6 \mathrm{ft}$.

\begin{tabular}{|c|c|}
\hline Each & \\
\hline 6 to 9 in........ & $\$ 1200$ \\
\hline 9 to 12 in....... 240 & 2100 \\
\hline
\end{tabular}

Dwarfer and more compact than the type. Japanese effect.

THUJA occidentalis, American Arborvitae. 40 to $60 \mathrm{ft}$.

Fine for hedges or for specimen planting.

\begin{tabular}{|c|c|c|c|}
\hline & Each & 10 & 100 \\
\hline 12 to 18 in. & . $\$ 40$ & $\$ 300$ & $\$ 24 \quad 00$ \\
\hline 18 to $24 \mathrm{in}$. & f0 & 440 & 3600 \\
\hline 2 to $3 \mathrm{ft}$. & 100 & 700 & 5000 \\
\hline 3 to $4 \mathrm{ft}$. & 150 & 1400 & 12000 \\
\hline 4 to $5 \mathrm{ft}$. & 250 & 2000 & $180-00$ \\
\hline 5 to $6 \mathrm{ft}$. & 350 & 3000 & \\
\hline
\end{tabular}
Becomes a dense, broad pyramid, the bright green foliage turning bronze in winter.

Hort. var. of Thuja occidentalis.

American Globe Arborvitae (cccidentalis globosa). 3 to $5 \mathrm{ft}$.

Dwarf round form very useful in formal plantings.

$$
12 \text { to } 18 \text { in...... } \begin{array}{rc}
\text { Each } & 10 \\
\$ 200 & \$ 1800
\end{array}
$$

American Pyramidal (occidentails pyramidalis). 15 to $30 \mathrm{ft}$.

Of narrow columnar form, much used in formal gardens, and where space is very limited and screen effect is desired.

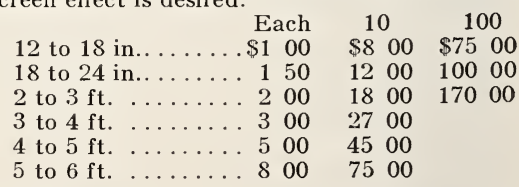

Golden American A. (cccidentalis autea). 15 to $20 \mathrm{ft}$.

Broad, bushy form with deep-yellow outer foliage.

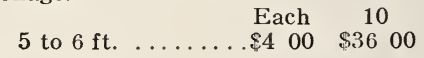

Siberian A. (cccidentalis wareana). 15 to $30 \mathrm{ft}$. Dense pyramidal form with stouter branchlets, bright green foliage of steelish cast.

$$
\begin{array}{rcc}
\text { Each } & 10 & 100 \\
12 \text { to } 18 \text { in.......\$1 } 25 & \$ 10 \text { c0 } & \$ 9000
\end{array}
$$




\section{HARLAN P. KELSEY, SALEM, MASSACHUSETTS}

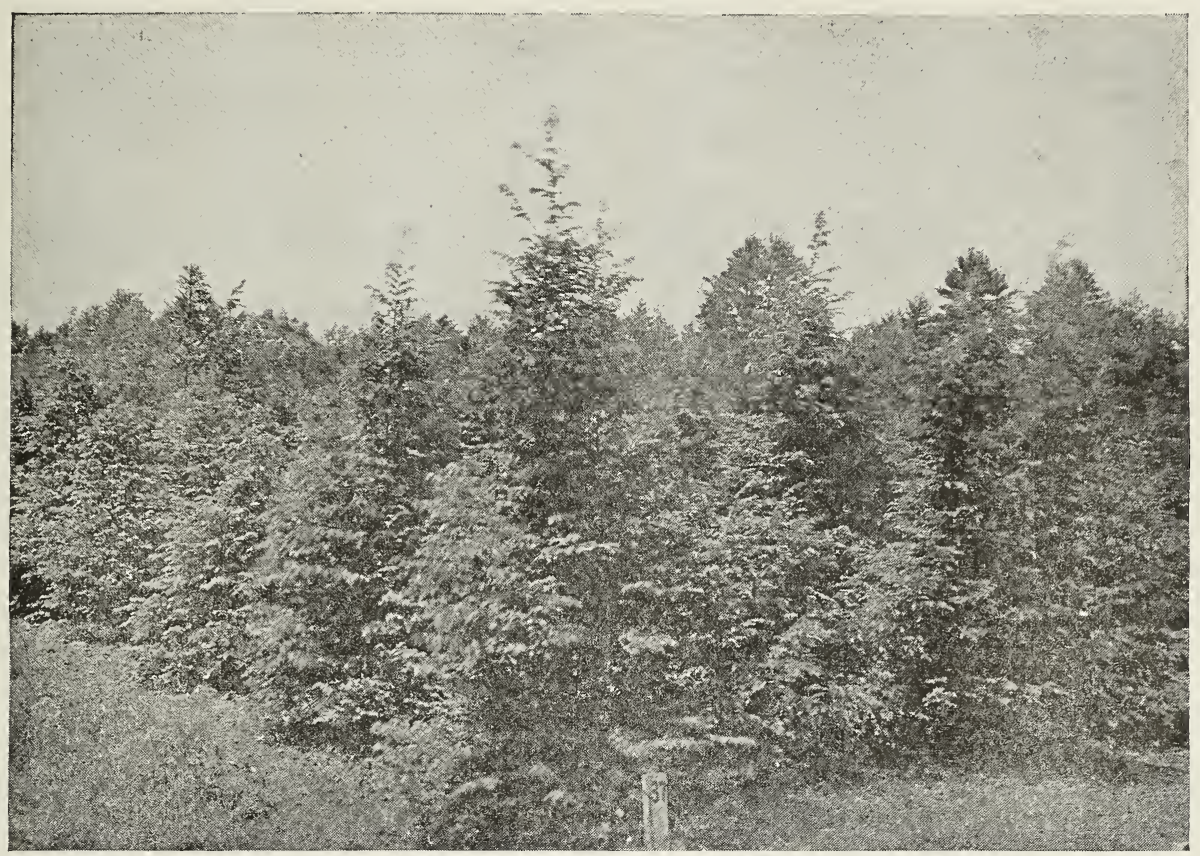

\section{Block of specimen Hemlocks at Boxford-Highlands Nursery}

(Foto by H. P. K.)

TSUGA canadensis, Common Hemlock. 50 to $125 \mathrm{ft}$.

Our beautiful common Hemlock, and one of the most conspicuous of our Eastern Mountain conifers. Does well either in partial shade or in the open and can be kept to any desired size by shearing. A fine hedge plant.

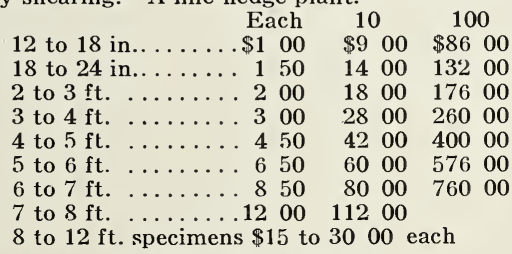

caroliniana, Carolina Hemlock.

Introduced by Harlan P. Kelsey in 1884, it has become known to tree lovers as the most distinctive and graceful of all conifers which are hardy throughout the entire United States. Its dense, dark foliage, sweeping semi-pendulous branches, and eventually pyramidal form, combine to give a charm not found in any other evergreen known to cultivation. It is much hardier and more adaptable to city atmospheres than its plainer sister, the Canadian Hemlock, and will also thrive in southern latitudes where the latter becomes thin, yellow and unsightly.
It is the "coming evergreen" for the finest landscape plantings, either as a single specimen or for mass effects and backgrounds and for hedges.

After the disastrous spring and winter of 191718, Prof. C. S. Sargent, Director of Arnold Arboretum, says of this tree: "Numerous specimens of the Carolina Hemlock (Tsuga caroliniana) have been uninjured by the cold and drought of the year. This is one of the handsomest of all cone-bearing trees which can be grown in this part of the country." And, again, in the Nov. 10, 1919, Bulletin of the Arnold Arboretum: "The handsomest of the Hemlocks which can be grown in Massachusetts and now one of the most beautiful trees in the Arboretum is a native of the Southern Appalachian Mountains,- Tsuga caroliniana." At Boxford-Highlands Nursery may be seen large blocks of the Carolina Hemlock, all specimens regardless of size.

$$
\text { Each } \quad 10 \quad 100
$$

9 to 12 in........\$ $100 \$ \$ 900 \$ 8000$

12 to 18 in......... $150 \quad 50 \quad 1400 \quad 13200$

18 to 24 in........ $225 \quad 2000 \quad 18000$

2 to $3 \mathrm{ft}$......... $350 \quad 3000 \quad 27000$

3 to $4 \mathrm{ft} . \ldots \ldots \ldots 6 \quad 600 \quad 5000 \quad 45000$

4 to $5 \mathrm{ft} . \ldots \ldots \ldots 1000 \quad 9000$

5 to $6 \mathrm{ft}$. $\ldots \ldots \ldots .1500 \quad 13500$

A few larger specimens $\$ 30$ to 7500 each 


\section{RHODODENDRONS AND OTHER BROADLEAF EVERGREENS AMERICAN RHODODENDRONS}

The American Native Rhododendrons are at last coming into their own. Being absolutely hardy as far north as Quebec they assure success where the half-hardy hybrids have so often proved a failure. Even where "hybrids" are used the dark foliaged American species should form the main background.

The sizes immediately following the names indicate the hights attained of the Trees, Shrubs, and Plants in a wild state; under cultivation they usually reach and often exceed the lesser hight given.

RHODODENDRON carolinianum, CAROLINA

RHODODENDRON.

A new American species. Clear pink. Abso-

lutely hardy. This is one of our finest introductions and fills a long-felt want for a hardy dwarf Rhododendron with flowers free from any hint of magenta. It was described and named by Alfred Rehder, of the Arnold Arbore-

tum. It is the smallest Alleghanian species, attaining a hight of 6 to 8 feet in cultivation. The thick-set leaves are dark-green, usually blunt and narrow, covered with rusty dots below, much smaller than either maximum or catawbiense. Flower clusters appear in greatest profusion in June, covering the plant with a rose-colored mantle. Fine for rocky slopes or hillsides, standing exposure unusually well and invaluable as a single specimen or for massing. Each 10

6 to 9 in........ $\$ \quad 60$ \$ 500

9 to 12 in....... $100 \quad 800$

12 to $18 \mathrm{in} \ldots \ldots \ldots .150 \quad 1400$

18 to 24 in. clumps $400 \quad 3900$

2 to $3 \mathrm{ft}$. clumps... $600 \quad 5700$

catawbiense. Catawba Rhododendron.

Of the Carolina Mountains. The hardiest of all Fhododendrons. It was this magnificent Rhododendron that over a hundred years ago was introduced into Europe, supplying, together with Rhododendron maximum, color and hardy blood to the cultivated "hybrids," but with a consequent loss of hardiness; and so today, for American gardens, where ironclad hardiness is essential, we must turn to the true original species, found on the loftiest, coldest peaks of the southern Alleghanies where it attains a hight of 20 to 30 feet. Considering the extreme hardiness, color of flower, compact growth, and remarkable texture of foliage, which is a deep, shining green, and far superior to the better-known Rhododendron maximum, we can recommend the true native catawbiense as the finest for general use, withstanding exposure and extremes of temperature where other Rhododendrons fail. Unlike Rhododendron maximum, it is a very free bloomer, with foliage of a dark, rich, lasting green, which never rusts. The trusses are a bright redpurple (in marled contrast to the muddy purple of the semi-hardy, half-breed imported variety), and as sent out by Boxford-Highlands Nursery is always on its own roots. For massing to produce a broadleaf evergreen landscape effect, there is no plant equal to it in the latitude of the northern United States and Canada, where strictly hardy plants must be employed. $\quad$ Each $10 \quad 100$ 9 to 12 in. clumps $\$ \$ 125 \quad \$ 1200 \$ 10000$ 12 to 18 in. clumps $175 \quad 1600 \quad 15000$ 18 to 24 in. clumps $275 \quad 2600 \quad 22000$ 2 to $3 \mathrm{ft}$. clumps... $400 \quad 3800 \quad 35000$ 3 to $4 \mathrm{ft}$. clumps . . $600 \quad 5600 \quad 54000$ 4 to $5 \mathrm{ft}$. clumps ... $900 \quad 8600$

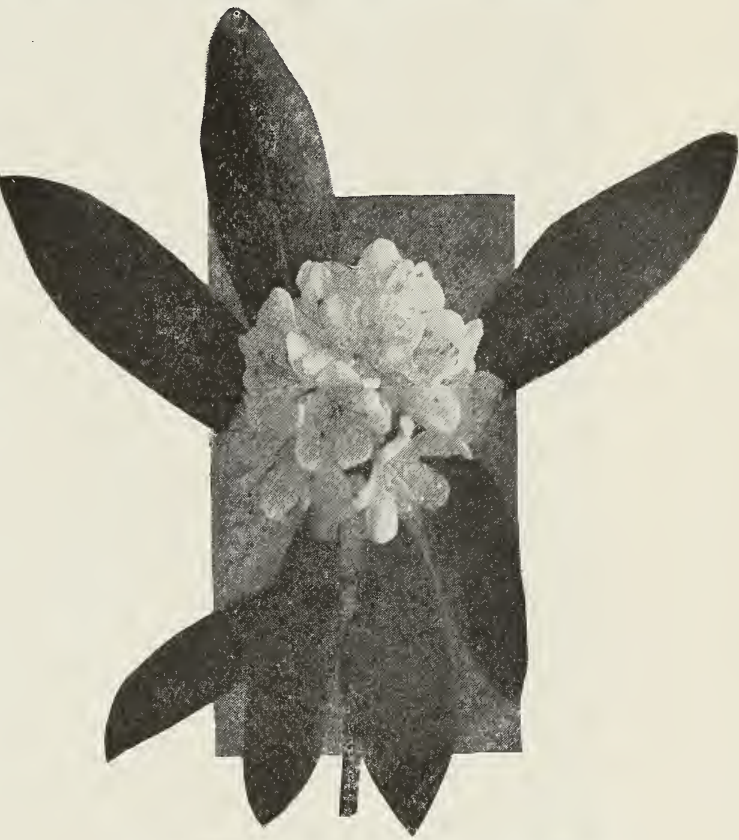

The rare $\mathrm{Rhododendron} \mathrm{carolinianum}$ A beautiful clear pink

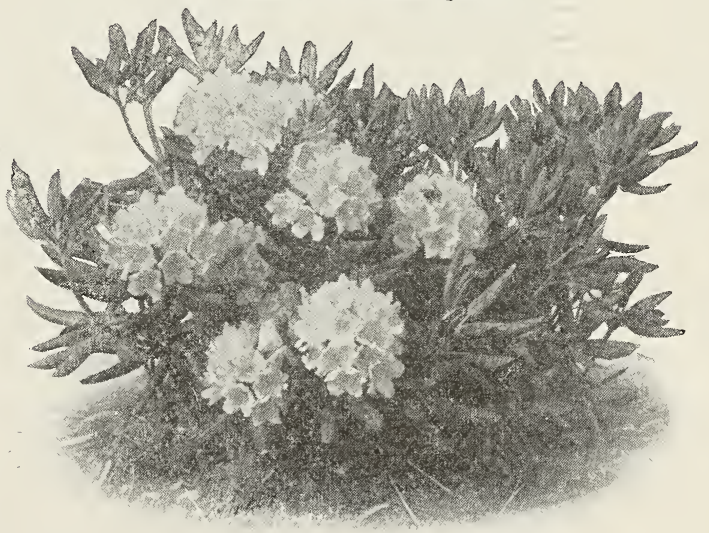

(Foto by H. P. K.)

Rhododendron catawbiense compacta New variety introduced by Harlan P. Kelsey 


\begin{tabular}{llll}
\hline KELSEY'S HARDY AMERICAN PLANTS & PLAN
\end{tabular}

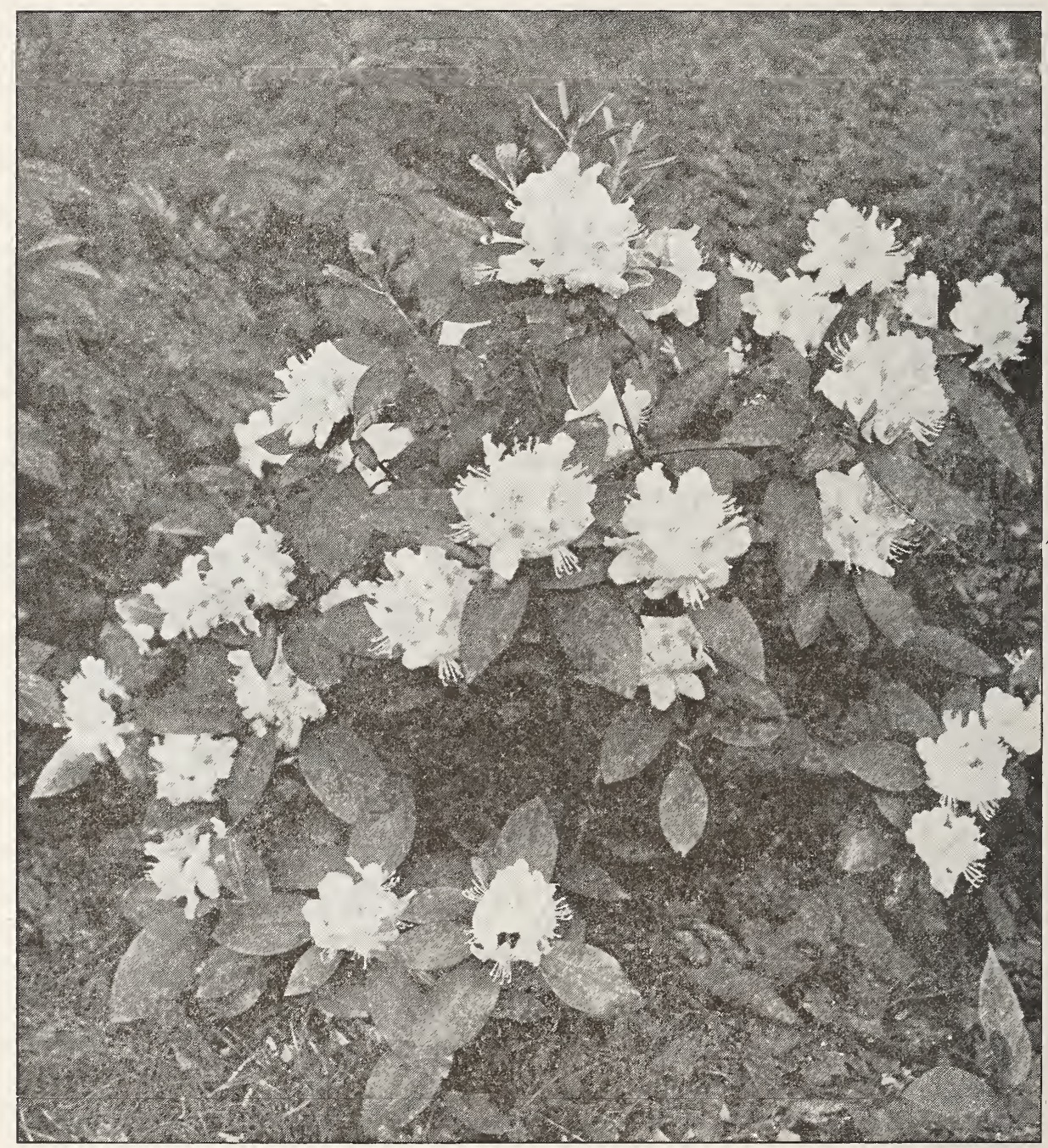

Carolina Rhododendron ( $R$. carolinianum), a beautiful new pink dwarf species introduced by Harlan P. Kelsey 


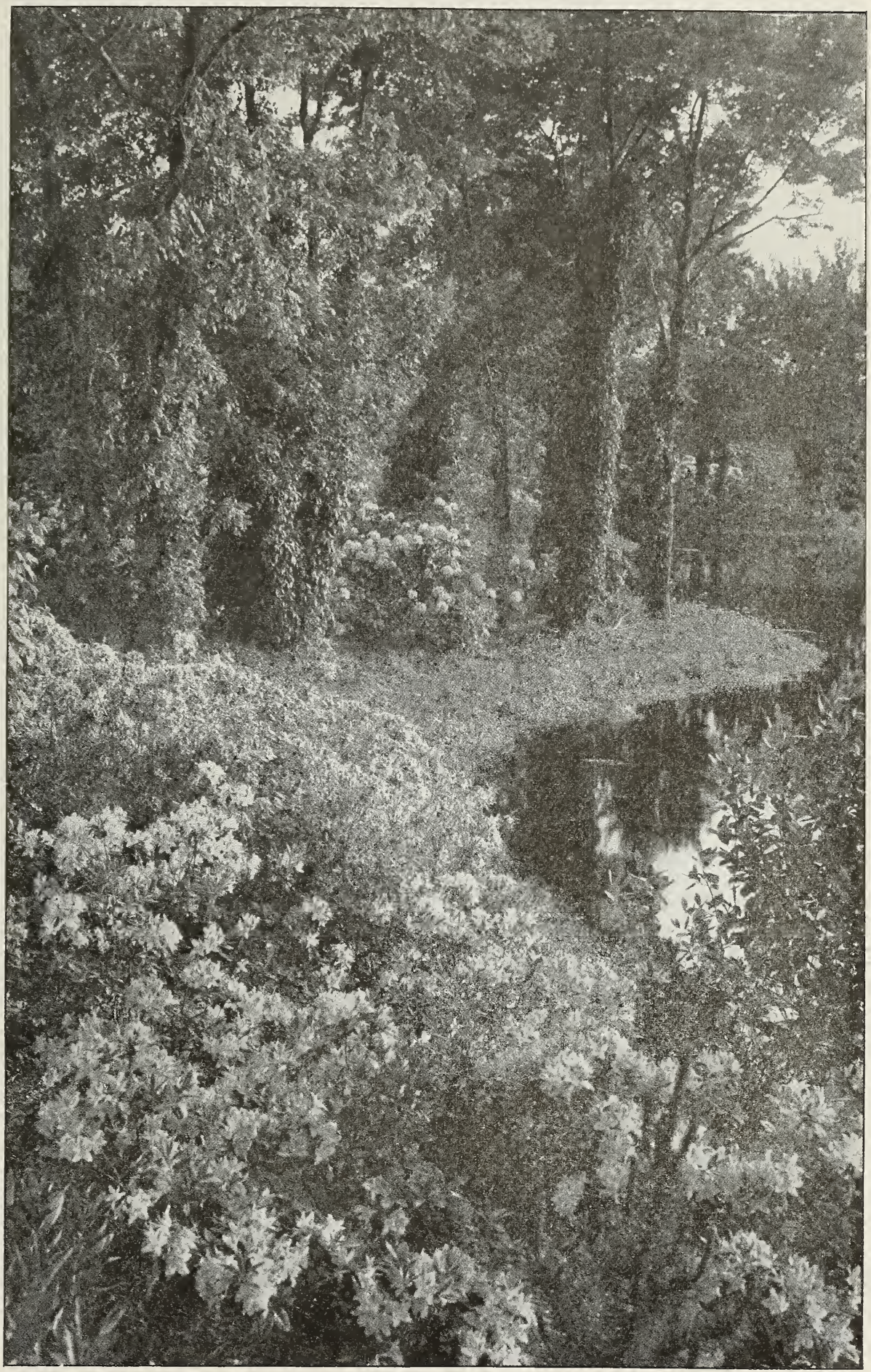

Hardy Rhododendrons and Azaleas thriving in an ideal location near Boxford-Highlands Nursery 


\section{\begin{tabular}{lllll}
\hline KELSEY'S HARDY AMERICAN PLANTS \\
\hline
\end{tabular}}

RHODODENDRON catawbiense compacta.

New Introduction of Harlan P. Kelsey. A very compact-growing form from the highest peaks of the Southern Alleghany Mountains with dark-green foliage, entirely distinct from the catawbiense type in usual cultivation.

\begin{tabular}{lrrrr} 
& Each & \multicolumn{2}{c}{10} \\
12 to 18 in. clumps & $\$ 250$ & $\$ 2100$ \\
18 to 24 in. clumps & 400 & 00 & 3000 \\
2 to $3 \mathrm{ft}$. clumps.. & 600 & 5700
\end{tabular}

maximum, Rosebay RHODODENDRON.

Rhododendron maximum or Rosebay Rhododendron is without doubt the noblest of American broadleaf shrubs. It is found growing sparingly in New England and New York, more abundantly in the Pennsylvania mountains, but reaching perfection only in the Southern Alleghany Mountains, where it grows in such luxuriance as to form a striking feature in the mountain landscape. Its large, waxy white or delicately pink flowers appear in large trusses in July, the latest of all the Rhododendrons, greatly enhancing its ornamental value as a broadleaf evergreen for finished landscape effect.

$\begin{array}{lrc} & \text { Each } & 10 \\ 12 \text { to } 18 \text { in. clumps } & 150 & \$ 1400 \\ 18 \text { to } 24 \text { in. clumps } & 200 & 1800 \\ 2 \text { to } 3 \mathrm{ft} \text {. clumps. . } & 300 & 2800 \\ 3 \text { to } 4 \mathrm{ft} \text {. clumps. . } & 450 & 4000 \\ 3 \text { to } 5 \mathrm{ft} \text { extra clumps } \$ 6 \text { to } 1000 \text { each }\end{array}$
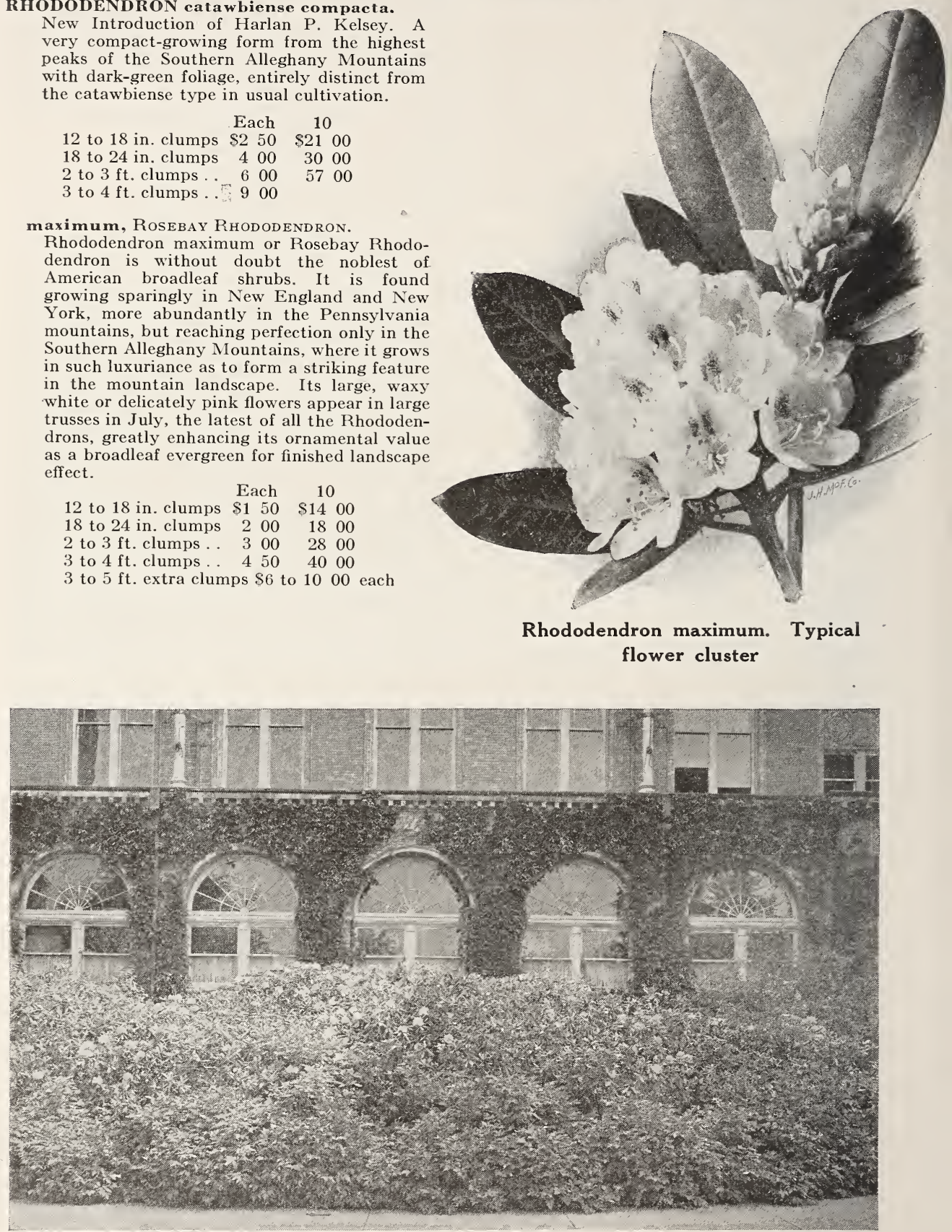

Rhododendron Bed at State Normal School, Salem. Planted by Harlan P. Kelsey. Note edging of Zanthorhiza

(Foto by H. P. K.) 


\section{HARLAN P. KELSEY, SALEM, MASSACHUSETTS}

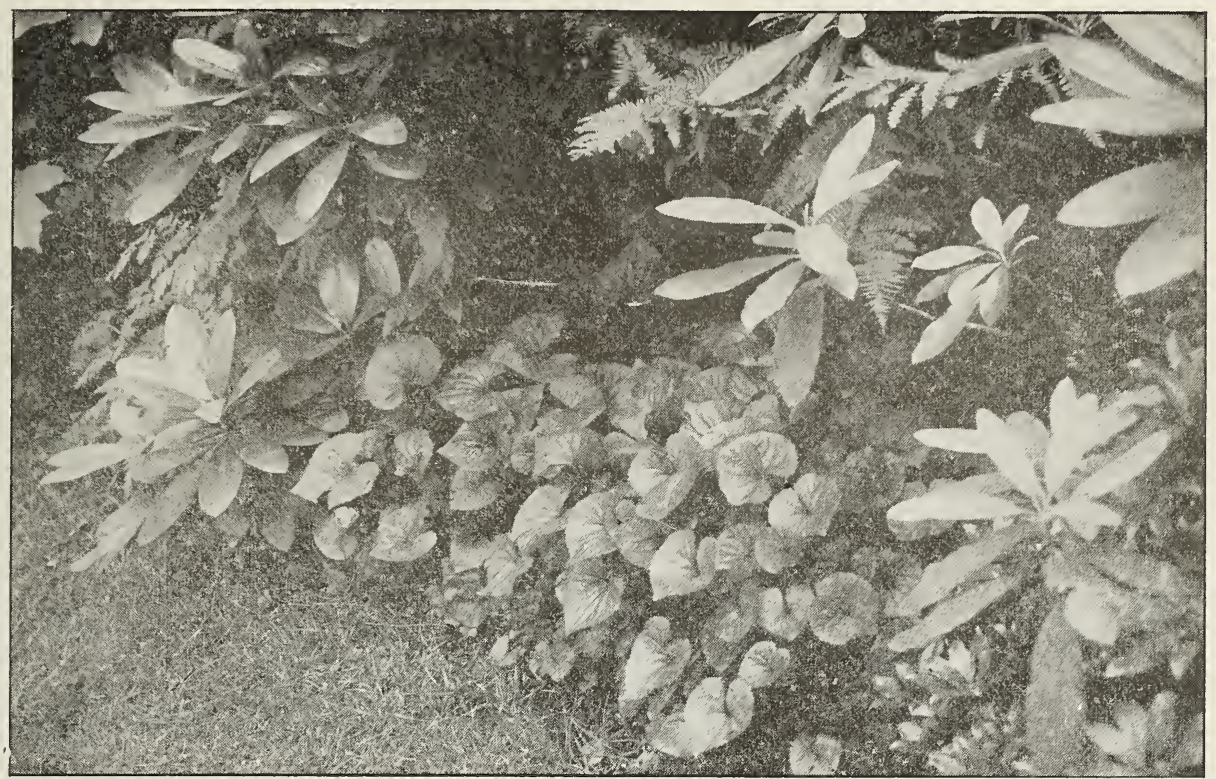

Rhododendron Bed. Detail of edging; Ferns, Violets and Fringe Bleedingheart

(Foto by H. P. K.)

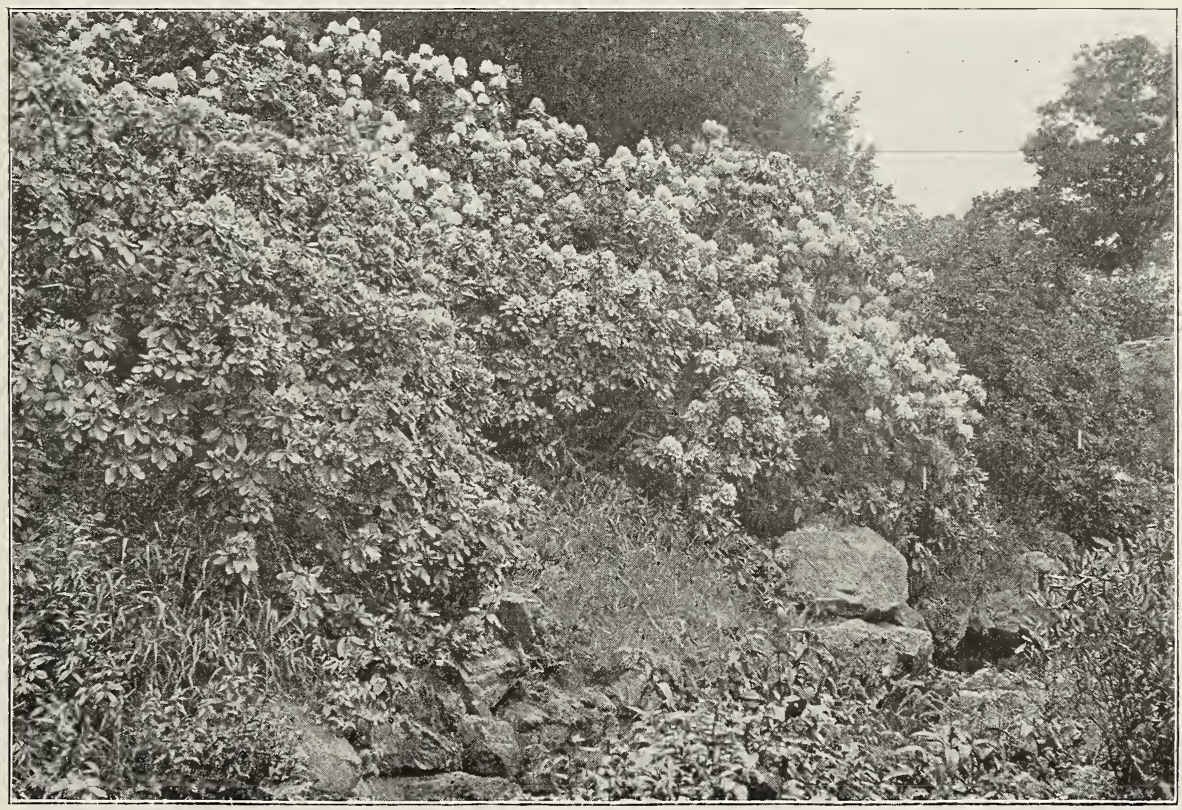

Mass of Rhododendrons with Hemlock background at Arnold Arboretum

(Foto by H. P. K.) 
Horticultural varieties of $\mathbb{B}$ hododendron.

Hybrids of R. catawbiense.

We have only the hardiest sorts. They are becoming difficult to secure, owing to Federal Quarantine Regulations shutting out all foreign-grown stock.

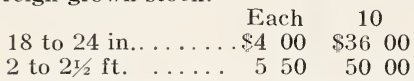

Album Elegans, blush, changing to white.

Caractacus, purplish crimson.

CHARLES DICKENS, dark scarlet.

E. S. RAND, rich scarlet.

F. D. Godman, crimson.

HANNIBAL, rosy red-violet.

IGNATIUS SARGENT, deep pink.

LUTEO-ROSEUM, satin rose suffused with white, center light yellow.

Mrs. Milner, crimson.

Parsons Gloriosum, blush.

Parsons Grandiflorum, rose.

Purpureum elegans, dark purple.

Roseum elegans, rose.

Myrtle (myrtifolium)

A fine hardy hybrid between R. minus and R. hirsutum. This variety is very' useful for the rockery, and the borders of the Rhododendron bed. Covered with clusters of deep rosy-pink flowers.

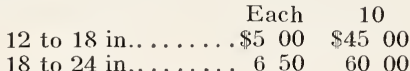
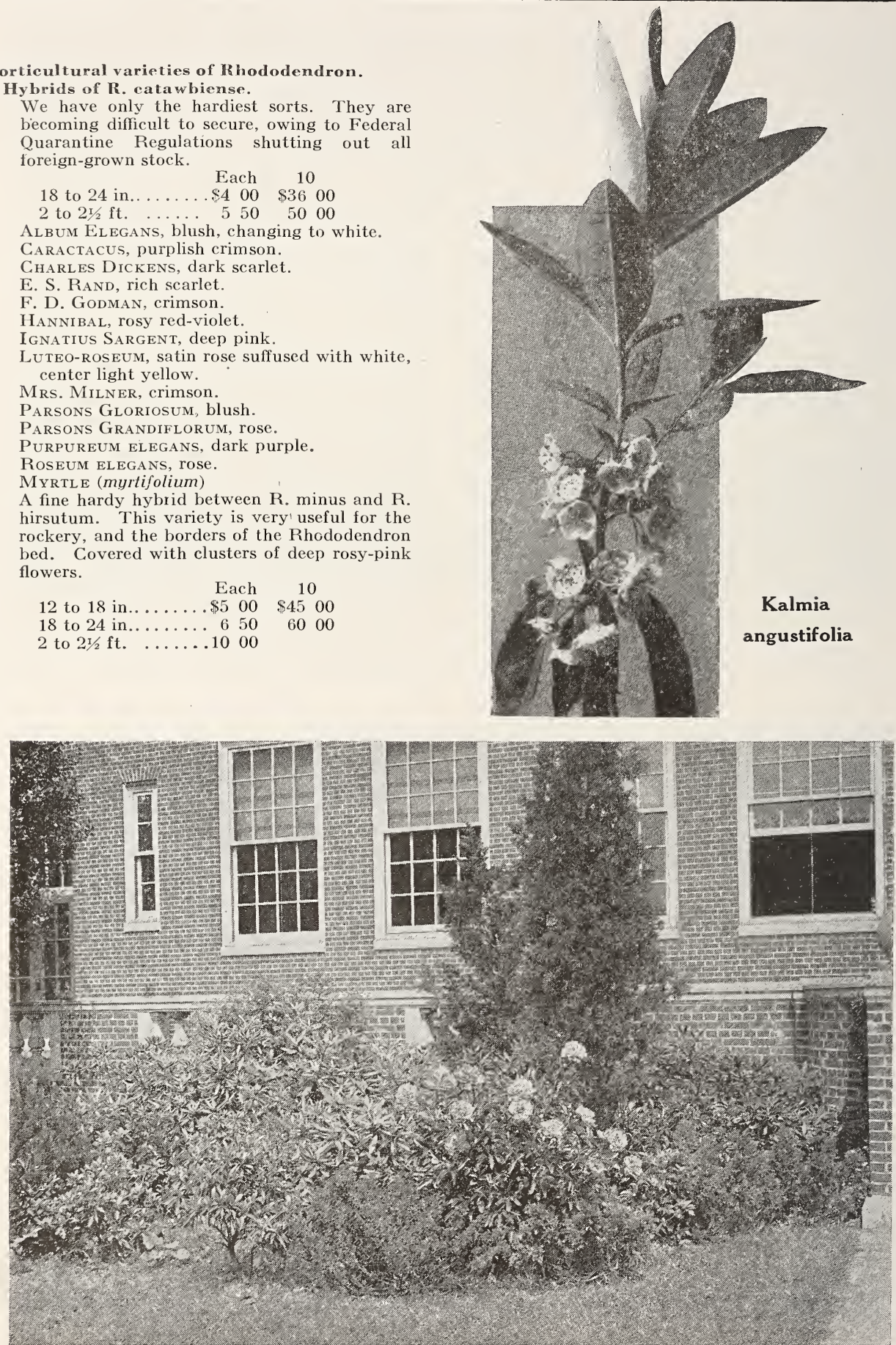

Base Planting (first season) of Mixed Shrubs and Rhododendrons at Saltonstall School, Salem

(Foto by H. P. K.) 


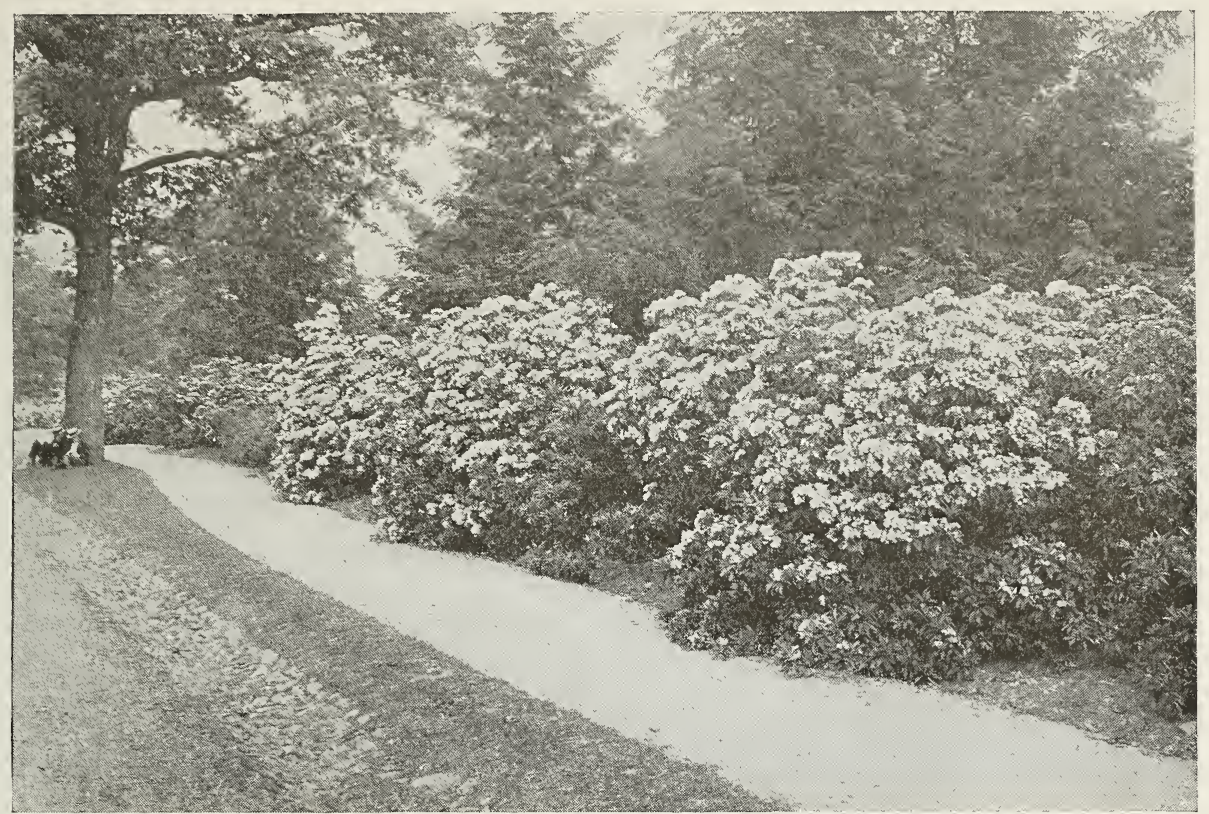

\section{Other Hardy Broadleaf Evergreens}

ANDROMEDA polifolia, Bogrosemary. 6 in. to $2 \mathrm{ft}$.

A beautiful dwarf species of our Northern bogs. Grows well in rich borders. Dainty bellflowers of delicate pink. June.

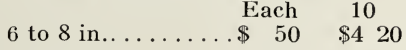

ARCTOSTAPHYLOS uvaursi, BEARBERRy. Prostrate.

This delightful trailing plant is invaluable for seashore and other ground cover planting, forming solid dense mats of green. Thrives in sandy soil when established. Difficult to transplant unless pot-grown plants are used. Bright red berries.

$$
\begin{aligned}
& \begin{array}{rrr}
\text { Each } & 10 & 100
\end{array} \\
& 2 \text { in. pots .......\$ } 80 \quad \$ 760 \quad \$ 6000 \\
& 31 / 2 \text { in. pots } \ldots \ldots 100 \quad 900
\end{aligned}
$$

CHAMAEDAPHNE calyculata, LeAtherleaf. 1 to $3 \mathrm{ft}$.

A fine, hardy border plant for the Rhododendron bed or very moist locations. White nodding flowers in leafy racemes in early spring.

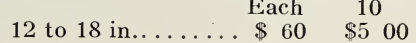

DAPHNE cneorum, Rose Daphne. 6 to 12 in. Trailing evergreen, glossy narrow leaves and a profusion of bright pink fragrant flowers in May and often again in August.

$$
6 \text { to } 9 \text { in........ Each } \quad \$^{10} \quad \begin{array}{cc}
100 \\
\$ 500 & \$ 4000
\end{array}
$$

KALMIA angustifolia, LAMBKILL. 2 to $3 \mathrm{ft}$.

Makes a fine ground cover A charming, dwarf sort of the same general character as latifolia, forming dense, low clumps. In early spring showy clusters of wheel-shaped, deep rose-colored flowers.

$$
\text { Each } 10
$$$$
12 \text { to } 15 \text { in......\$ } 60 \quad \$ 500
$$

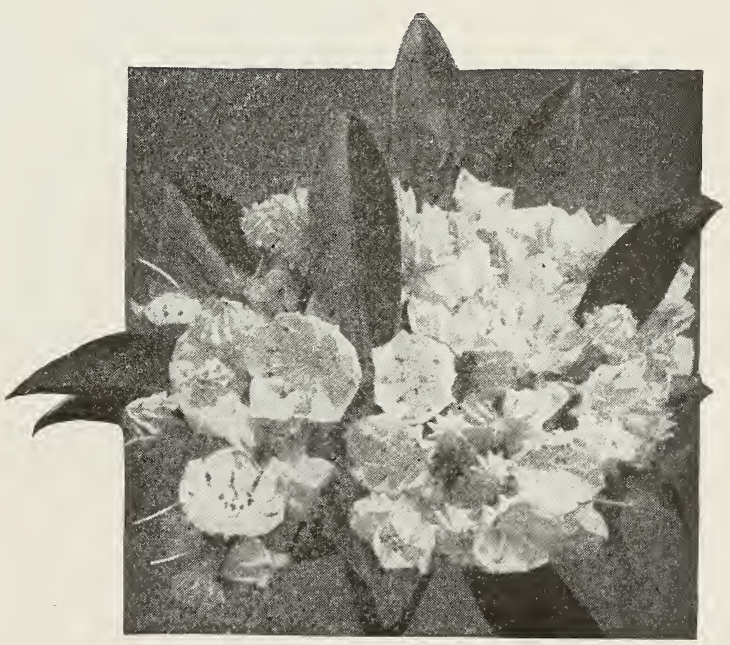

Detail of Kalmia latifolia blossom 


\begin{tabular}{llll}
\hline KELSEY'S HARDY AMERICAN & PLANTS \\
\hline
\end{tabular}

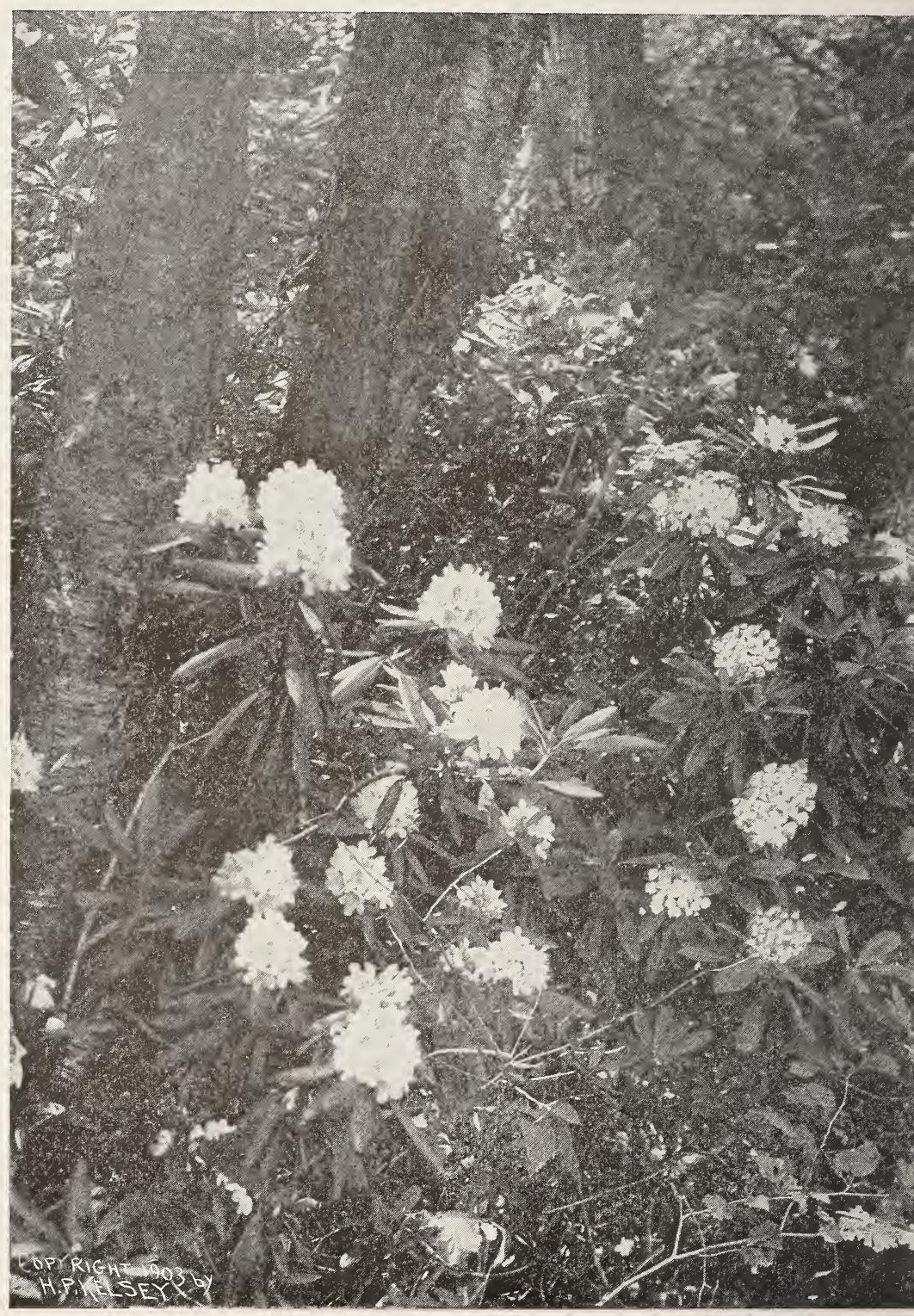

Rhododendron maximum, charming 


\section{\begin{tabular}{llll}
\hline KELSEY'S HARDY AMERICAN & PLANTS
\end{tabular}}

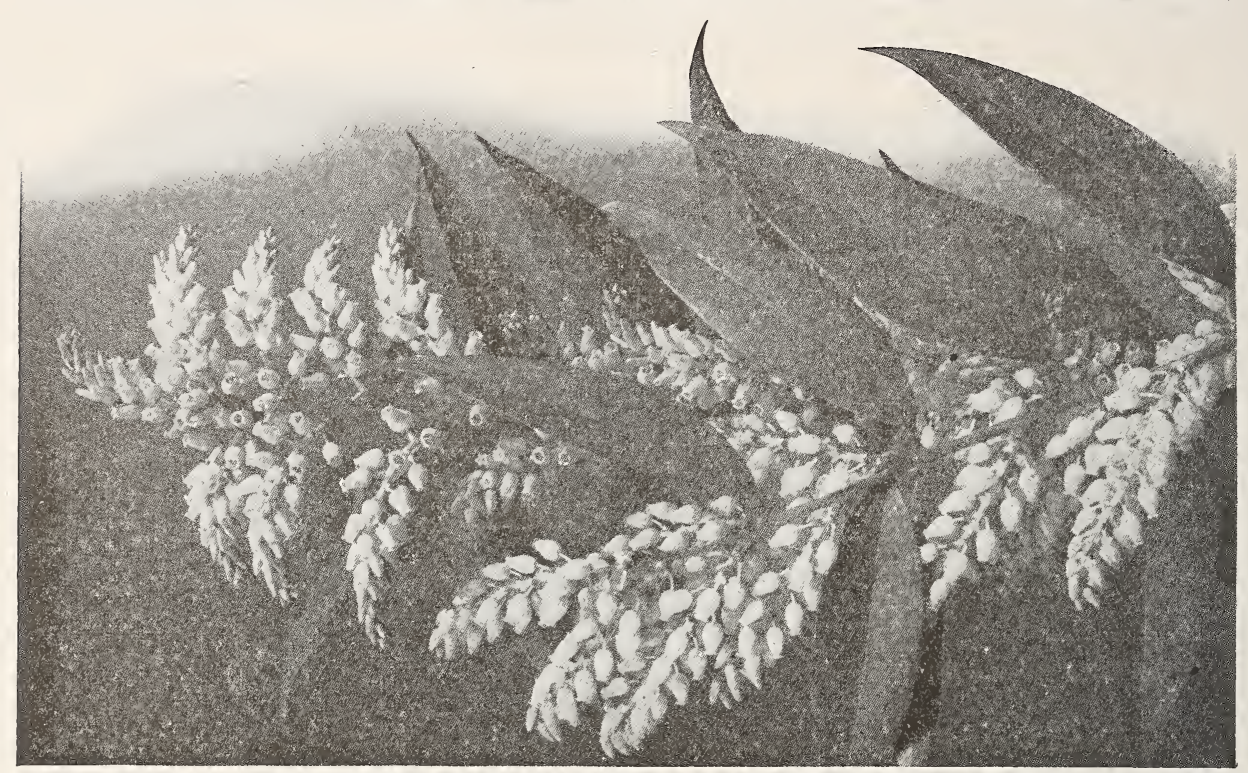

\section{Sprays of Leucothoe catesbaei, the most beautiful edging for Rhododendron plantings}

KALMIA latifolia, Kalmia (Mountain Laurel). 4 to $25 \mathrm{ft}$.

One of the grandest of our native broadleaf evergreen shrubs, attaining tree-like proportions in our Southern mountains. In cultivation it is a broad, thick shrub, and, when in full bloom, of surpassing beauty. The wheelshaped flowers in close terminal corymbs, pure white to pink, appear in May or June in such profusion as almost to smother the foliage. Its thick, shining leaves, conspicuous the year round, make it a shrub of greatest value for massing. The hardiness of Kalmia latifolia is beyond doubt, it being found sparingly in Nova Scotia, and increasingly in abundance through New England and the middle Atlantic States (particularly in the higher altitudes), till the crest of the Southern Alleghanies is reached.

\begin{tabular}{lrrrrrr} 
& Each & \multicolumn{2}{c}{10} & \multicolumn{2}{c}{100} \\
9 to 12 in. clumps & $\$ 125$ & $\$ 10$ & 00 & $\$ 90$ & 00 \\
12 to 18 in. clumps & 1 & 75 & 16 & 00 & 114 & 00 \\
18 to 24 in. clumps & 3 & 00 & 28 & 00 & 255 & 00 \\
2 to 3 ft. clumps.. & 4 & 00 & 36 & 00 & 340 & 00
\end{tabular}

LEIOPHYLLUM buxifolium, Box SANDMYRtLE. 1 to $3 \mathrm{ft}$.

A dainty low shrub with small, narrow evergreen leaves, and in May or early June profusely covered with white heath-like flowers set with pink stamens.
9 to 12 in. ......\$ $75 \$ \$ 600$
12 to 18 in....... $125 \quad 900$

LEUCOTHOE catesbaei, Drooping LeUCothoE. 3 to $8 \mathrm{ft}$.

Few shrub evergreens of the broadleaf sort have the grace of this one. The thick, shining green leaves are evenly disposed on long recurved branches with dense racemes of beautiful, white, bell-shaped flowers. As an under-shrub or for banks and borders of streams it is without a rival. One of the most useful of all evergreens for edging the Rhododendron or Azalea plantation. The sprays make beautiful winter decorations indoors, turning a rich bronze in the fall where exposed to the sun. Thousands of specimen clumps at BoxfordHighlands Nursery.

\begin{tabular}{lrlllll} 
& Each & \multicolumn{2}{c}{10} & \multicolumn{2}{c}{100} \\
12 to 18 in. clumps & $\$ 100$ & $\$ 8$ & 60 & $\$ 80$ & 00 \\
18 to 24 in. clumps & 1 & 50 & 14 & 00 & 120 & 00 \\
2 to $3 \mathrm{ft}$. clumps. . & 2 & 25 & 20 & 00 & 192 & 00 \\
2 to $3 \mathrm{ft}$. extra clumps 3 & 50 & 30 & 00 & 270 & 00
\end{tabular}

PACHYSANDRA terminalis, JAPANESE PACHYSANDRA. 6 to 9 in.

A low shrub largely used as a ground cover in dense shade and for edging shrubberies. Foliage glossy, light green.

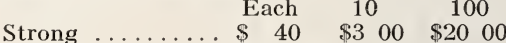

PIERIS (Andromeda) floribunda, Mountain ANDROMEDA. 2 to $6 \mathrm{ft}$.

One of the finest of all broadleaf American shrubs. Compact growth, with shining evergreen leaves and abundant racemes of showy white flowers in May. The next season's buds appear after the flowering season and give the plant the appearance of being in bloom the year round. My stock is all strictly Americangrown.

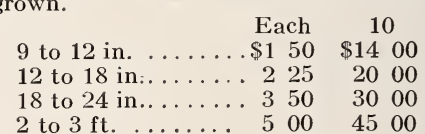




\section{"COLLECTED" RHODODENDRONS AND KALMIAS}

The most striking landscape effects are produced by massing our wonderful native broadleaf evergreens. I grow them by thousands and supply also a select grade of "collected" clumps, that will give immediate effect, each plant a specimen balled and burlaped. The "cheap" collected stock sent out by "mushroom" collectors often fails - the best is always cheapest. The native species are hardy. These clumps mav be safely shipped from early spring till June first, then again in August and thru the fall months, but early shipments are always desirable.

\section{KALMIA LATIFOLIA}

1 to 2 ft. "collected" clumps

2 to $3 \mathrm{ft}$. "collected" clumps.

3 to $4 \mathrm{ft}$. "collected" clumps.

RHODODENDRON CATA WBIENSE (True Species)

The finest hardy broadleaf evergreen for foliage effects.

1 to $2 \mathrm{ft}$. "collected" clumps.

2 to $3 \mathrm{ft}$. "collected" clumps.

3 to $4 \mathrm{ft}$. "collected" clumps.

4 to $5 \mathrm{ft}$. "collected" clumps.

RHODODENDRON MAXIIUUII

1 to $2 \mathrm{ft}$. "collected" clumps

2 to $3 \mathrm{ft}$. "collected" clumps.

3 to $4 \mathrm{ft}$. "collected" clumps.

4 tc $5 \mathrm{ft}$. "collected" clumps.

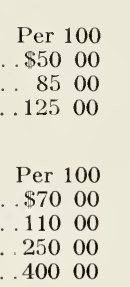

Per 100

$\$ 6000$

9000

14000

22500
Approx.

Per $1000 \quad$ No. to car $\$ 45000 \quad 1000-1400$ $70000 \quad 700-1000$ $110000 \quad 500-700$

$\begin{array}{cc} & \text { Approx. } \\ \text { Per 1000 } & \text { No. to car } \\ \$ 60000 & 1000-1400 \\ 85000 & 700-1000 \\ & 500-700 \\ & 300-400 \\ & \text { Approx. } \\ & \text { No. to car } \\ \text { Per 1000 } & 1000-1400 \\ \$ 55000 & 700-1000 \\ 75000 & 500-700 \\ 125000 & 300-400\end{array}$

Burlaping is recommended and will be charged for as per schedule on page 1.

An extra grade of selected collected clumps can be supplied at 25 per cent to 50 per cent advance to above prices, depending on how perfect the specimens are.

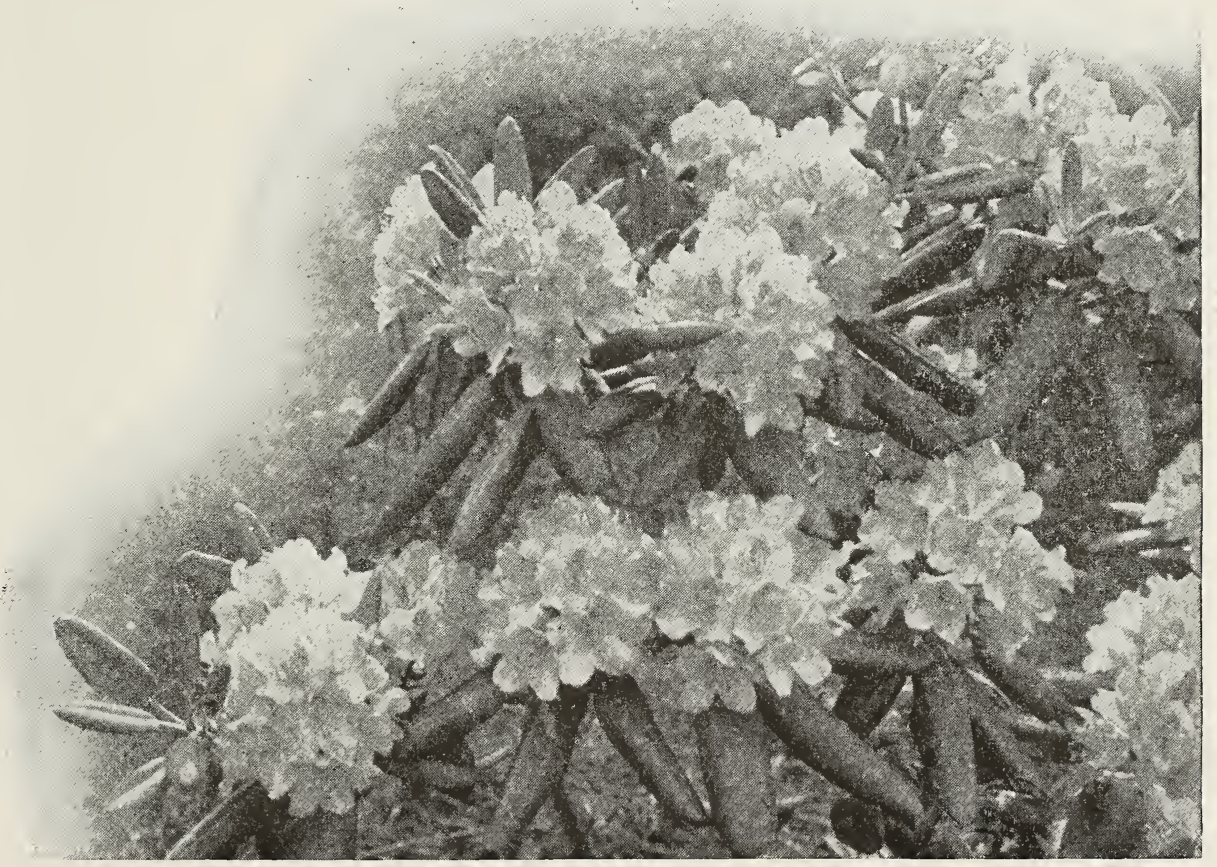

The true RHODODENDRON CATAWBIENSE. Red-purple The finest foliaged of all Rhododendrons 


\section{DECIDUOUS TREES AND SHRUBS}

\section{The sizes immediately following the names indicate the hights attained of the Trees, Shrubs, and Plants in a wild state; under cultivation they usually reach and often exceed the lesser hight given.}

$\begin{array}{cc}\text { ACER bucrgerianum. Each } & 10 \\ 12 \text { to } 15 \text { in........ } 60 \quad \$ 400\end{array}$

dasycarpum (sacharinum), Silver Maple.

50 to $120 \mathrm{ft}$.

Rapid growth; open, pendulous habit; light green leaves; for quick effects desirable, but not as desirable for general use as many other species.

14 to $18 \mathrm{ft}$. . . \$5 to 1250 each ginnala, AMUr MAPle. 12 to $20 \mathrm{ft}$

Handsome foliage, turning bright red in autumn. Each $10 \quad 100$

2 to $3 \mathrm{ft} . \ldots \ldots \ldots . \$ 75 \quad \$ 500 \quad \$ 4500$

4 to $8 \mathrm{ft}$. clumps...\$2 to 400 each platanoides, NorWay MAPLE. 50 to $100 \mathrm{ft}$.

Large, handsome tree, much used for street planting. Leaves turn pale yellow in fall.

$\begin{array}{rrrrr}\text { Each } & 10 & 100 \\ 6 \text { to } 8 \mathrm{ft} & \ldots \ldots \ldots . \$ 150 & \$ 12 & 00 & \$ 100\end{array}$

8 to $10 \mathrm{ft} .11 / 4$ to $1 \frac{1}{2}$

in cal. ......2 $00 \quad 1800 \quad 17600$

8 to $10 \mathrm{ft} .13 / 4$ to 2 in.

cal.......... $300 \quad 2800$

10 to $12 \mathrm{ft} .13 / 4$ to 2

in. cal. ....... $350 \quad 3000 \quad 28000$

10 to $12 \mathrm{ft} .2$ to $2 \frac{\mathrm{r} / 2}{2} 4003600$
in. cal. ......4

10 to $12 \mathrm{ft} .3 \mathrm{y} / 2$ to 4

in. cal. .......450 40 400

12 to $14 \mathrm{ft} .2$ to $2 \frac{1}{2}$

in. cal. ...... $450 \quad 4000$

12 to $14 \mathrm{ft} .3 \frac{1}{2}$ to 4

in. cal. ...... $500 \quad 4500$

12 to $14 \mathrm{ft} .4$ to $5 \mathrm{in}$. cal. specimen $\$ 1000$ to $\$ 1500$ each.

rubrum, RED MAPLE. 50 to $120 \mathrm{ft}$.

One of our most beautiful native trees. Attractive at all seasons. Very early scarlet flowers followed by bright red fruit in early spring; bright scarlet and orange foliage in autumn.

\begin{tabular}{|c|c|c|}
\hline & Each & 10 \\
\hline 2 to $3 \mathrm{ft}$. & $\ldots \$ 35$ & $\$ 320$ \\
\hline 3 to $4 \mathrm{ft}$. & 50 & 400 \\
\hline to $5 \mathrm{ft}$. & 75 & \\
\hline to $6 \mathrm{ft}$. & . 100 & 800 \\
\hline to $8 \mathrm{ft}$. & $\ldots 200$ & 16 \\
\hline
\end{tabular}

charum, Sügar MAPLE. 60 to $120 \mathrm{ft}$

One of our best known and finest shade and street trees; of upright dense growth; leaves turn bright yellow and scarlet in autumn.

$\begin{array}{lll}\text { Each } & 10 & 100\end{array}$

4 to $6 \mathrm{ft} . \ldots \ldots \ldots \& 75 \quad \$ 600 \quad \$ 4800$

6 to $8 \mathrm{ft} . \ldots \ldots \ldots \ldots 125 \quad 1000 \quad 8800$

8 to $10 \mathrm{ft} . \ldots \ldots 2001800$

spicatum, Mountain Maple. 5 to $30 \mathrm{ft}$.

Dwarfish, good for undergrowth and the

border. Each 10

2 to $3 \mathrm{ft}$. Seedlings $\$ 25 \$ 200$

Hort, var. of Acer.

Wier Maple (dasycarpum wieri). 50 to $75 \mathrm{ft}$.

Weeping variety of considerable beauty.

10 to $14 \mathrm{ft}$. $\$ 3$ to 1000 each

A MELANCHIER canadensis, Downy Shadblow. 15 to $60 \mathrm{ft}$.

The Carolina mountain form, with largepanicled, showy white flowers and delicious fruit.

Each 10

4 to $5 \mathrm{ft} . \ldots \ldots \ldots . \$ 60 \quad \$ 400$

AMORPIIA tennesseenis, Tennessee Indigo. 5 to $20 \mathrm{ft}$.

Flowers violet-purple, one of the best of the genus. $\quad$ Each $10 \quad 100$ 2 to $3 \mathrm{ft}$. Seedlings. $\$ 25 \quad \$ 200 \quad \$ 1500$
ARONIA arbutifolia, Red Chokeberry. 6 to $10 \mathrm{ft}$.

One of our most showy, red-fruited shrubs for winter effect and for planting in Rhododendron beds and in shrubberies; autumn coloring $\begin{array}{llll}\text { bright scarlet. } \quad \text { Each } & 10 & 100\end{array}$ 9 to 12 in....... \$ $40 \quad \$ 350 \$ 3000$

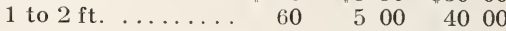

atropurpurea (floribunda), PURPLE ChokeBERRY. 6 to $12 \mathrm{ft}$.

Purplish black fruit. All the Aronias have showy white flowers and conspicuous fruit.

$$
6 \text { to } 9 \text { in....... Each } 40 \quad \$ 350
$$

melanocarpa, Black ChokeBerRy. 3 to $6 \mathrm{ft}$. Dense growth; fine for border; black fruit and masses of showy white blossoms.

\begin{tabular}{lrrrrr} 
& Each & 10 & \multicolumn{1}{c}{100} \\
18 to 24 in. clumps & $\$ 45$ & $\$ 400$ & $\$ 3500$ \\
2 to $3 \mathrm{ft}$. clumps ... & 60 & 500 & 4000 \\
3 to $4 \mathrm{ft}$. clumps .. & 80 & 720 & 6000 \\
4 to 5 ft. clumps . . & 100 & 800 & &
\end{tabular}

melanocarpa elata, Glossy Chokeberry. 6 to $10 \mathrm{ft}$.

A tall broad form of previous species.

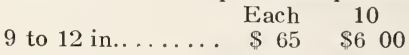

melanocarpa grandifolia, GREAT BLACK CHOKEBERRy. 6 to $10 \mathrm{ft}$.

Fruit black and lustrous, drooping on long stems and remains on plant until beginning of winter. Each 10

$2 \mathrm{t} / 2$ to $3 \mathrm{ft} . \ldots \ldots \quad \$ 50 \quad \$ 400$

3 to $4 \mathrm{ft} . \ldots \ldots \ldots .650$

melanocarpa and Clethra alnifolia, Mixed Clumps.

2 to $4 \mathrm{ft}$. clumps $\$ 2$ to $\$ 600$ each

AZALEA arborescens, Sweet Azalea. 8 to $20 \mathrm{ft}$. In June the delightfully spicy, fragrant white flowers, with pink stamens, appear in profusion, lasting for weeks. Becomes a spreading clump 3 to 6 feet broad in cultivation; easy culture. The foliage of this variety often colors striking shades of red in late autumn, and is the best of all the genus. The clumps offered have from twenty-five to one hundred stems and are heavily budded.

Each $\quad 10 \quad 100$

12 to 18 in. clumps $\$ 175 \quad \$ 1600 \quad \$ 14000$

18 to 24 in. clumps $300 \quad 2800 \quad 26000$

2 to $3 \mathrm{ft}$. clumps.. $450 \quad 4200 \quad 40000$

$\begin{array}{llllllll}3 \text { to } 4 \mathrm{ft} \text {. clumps } \ldots & 7 & 00 & 64 & 00 & 600 & 00\end{array}$

lutea (calendulacea), Flame Azalea. 6 to $15 \mathrm{ft}$. The most regal of all the species, native or exotic, and a noble representative of our rich Carolina mountain flora. Bartram, speaking of it in his "Travels," calls it the "fiery Azalea," and says: "This epithet fiery I annex to this most celebrated species of Azalea as being expressive of the appearance of its flowers, which are in general of the color of the finest red lead, orange, and bright gold as well as yellow and cream color. This is certainly the most gay and brilliant-flowering shrub yet known." No more striking landscape effect can be produced than a hillside of A. lutea in full bloom. Nearly all quoted above 18 in. are budded. These $\mathrm{A}$. lutea are splendid clumps with a mass of buds, and range in color from 
light sulphur-yellow to deep red. Where the eolors are picked, a special eharge will be made. Each $\quad 10 \quad 100$

18 to 24 in. clumps $\$ 200 \quad \$ 1800 \quad \$ 17200$ $\begin{array}{llllllll}2 \text { to } 3 \mathrm{ft} \text {. clumps.. } & 3 & 00 & 28 & 00 & 260 & 00\end{array}$ $\begin{array}{lllllll}3 & \text { to } 4 \mathrm{ft} \text {. elumps: } \quad 500 & 58 & 00 & 440 & 00\end{array}$ Selected eolors double prices above.

AZalea vaseyi, Pinksheli. Azalea. 6 to $15 \mathrm{ft}$. This showy Azalea was discovered only as late as 1878 , and introduced by Highlands Nursery very soon after. It is of easy eulture, and is perhaps the most profuse bloomer of all the native speeies, and the more conspicuous, as its white, pink, or deep rose-colored flowers appear in early April or May before the foliage. Of ereet, slender habit naturally, in cultivation it beeomes more spreading, while retaining the eharming light stem growth. Autumn usually turns the leaves a deep dark crimson, greatly enhaneing its beauty and value. Eaeh $10 \quad 100$ 12 to 18 in $\ldots \ldots \$ 25 \$ \$ 1000 \$ 9000$ 18 to 24 in........ $225 \quad 2000 \quad 18000$ 2 to $3 \mathrm{ft} . \ldots \ldots \ldots 350 \quad 3200 \quad 30000$ 3 to $4 \mathrm{ft} . \ldots \ldots \ldots 500 \quad 4800$

viscosa, Swamp Azalea. 5 to $15 \mathrm{ft}$.

Late-blooming with small, white, fragrant flowers in June and July. Arborescens and viseosa love moisture.

$$
\text { Each } 10 \quad 100
$$

12 to 18 in. clumps $\$ 100 \quad \$ 800 \$ 7200$

18 to 24 in. clumps $1 \quad 75 \quad 16 \quad 00 \quad 140 \quad 00$

2 to $3 \mathrm{ft}$. elumps... $300 \quad 2800 \quad 26000$ yodogawa, Lavender Azalea. 4 to $10 \mathrm{ft}$.

A hardy Japanese or Korean variety with spreading habit. Flowers quite double, rosepurple.

15 to 18 in......\$2 50 each

BERBERIS sieboldi, Siebold Barberry. 2 to $4 \mathrm{ft}$.

Leaves purplish when young, deep vinous red in autumn. Bright lustrous red fruit.

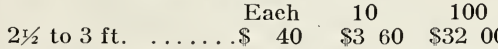

thunbergi, JAPANESE BARBERRY. 2 to $10 \mathrm{ft}$. One of the best known of hedge plants; eompact growth and scarlet fruit.

\begin{tabular}{rrrr}
12 to 18 in......... $\$ 40$ & \multicolumn{1}{c}{10} & \multicolumn{1}{c}{100} \\
18 to 24 in... & 20 & $\$ 2800$ \\
4 & 60 & 480 & 4000
\end{tabular}

18 to 24 in......... $60 \quad 480 \quad 4000$

thunbergi maximowiczi. 2 to $10 \mathrm{ft}$.

An interesting variety of the type, with foliage bright green beneath. Each 10

18 to 24 in....... \$ $\$ 100$ \$ 800

2 to $3 \mathrm{ft} . \ldots \ldots \ldots 150 \quad 1200$

vulgaris, EUROPEAN BARBERRY, 4 to $10 \mathrm{ft}$.

One of the very best. Handsome in spring, with golden yellow flowers and light green foliage; bright scarlet fruit hanging through $\begin{array}{llll}\text { winter. } & \text { Each } 10 & 100\end{array}$

1 to $2 \mathrm{ft} . \ldots \ldots \ldots . \$ 35 \quad \$ 240 \quad \$ 2000$

2 to $3 \mathrm{ft} . \ldots \ldots \ldots .50 \quad 400 \quad 3000$

Hort. var. of Berberis.

BOX BARBERRY. 1 to $2 \mathrm{ft}$.

A dwarf horticultural form of thunbergi used for low hedges and edging.

$\begin{array}{rc}\text { Each } & 10 \\ 9 \text { to } 12 \text { in........ \$1 } 50 & \$ 1200 \\ 12 \text { to } 15 \text { in..... } 00 & 1800\end{array}$

BETUla alba, European White Birch. 40 to $60 \mathrm{ft}$.

Fine white bark; of great use for planting among evergreens for contrast; best effeet when plants have several stems.

$$
\begin{array}{llll}
\text { Each } & 10 & 100 & 1000
\end{array}
$$

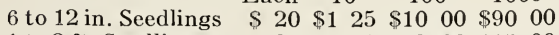

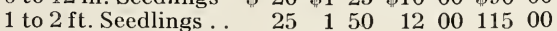
10 to $20 \mathrm{ft}$. $\$ 2$ to 1000 each
BETULA papyrifera (papyracea), CANOE BiRCH. 60 to $120 \mathrm{ft}$.

Very ornamental, white-barked tree, of greatest value for eontrasting cffects with evergreens.

$$
\begin{array}{rrrr}
6 \text { Each } & 10 & 100 \\
8 \text { to } 7 \mathrm{ft} . \ldots \ldots \ldots \$ 125 & \$ 1000 & \$ 8000 \\
8 \text { to } 10 \mathrm{ft} . \ldots \ldots \ldots 250 & 2000 & 16000
\end{array}
$$

populifolia, GRAY BiRCH. 15 to $40 \mathrm{ft}$.

Grown in clumps, is conspicuous as a graybarked shrub with delieate twigs and cut foliage.

$\begin{array}{ccc}\text { Each } & 10 & 100 \\ & & 0\end{array}$

6 to $12 \mathrm{in}$. Seedlings $\$ \quad 25 \quad \$ 125$
6 to $8 \mathrm{ft}$. . . . . . $100 \quad 800$

CALYCANTHUS floridus Common SweEtSHRUB. 3 to $6 \mathrm{ft}$.

Flowers dark reddish brown with spicy fragranee.

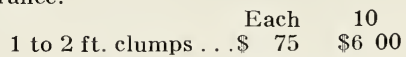

CARAGANA arborescens cuneifolia.

1 to $2 \mathrm{ft}$ Each 10

CARPINUS caroliniana (americana), AMERICAN HoRnBEAM. 15 to $40 \mathrm{ft}$.

Bushy small tree; dense but slender branehes; foliage colors orange-yellow and scarlet in fall. Fine as a clipped hedge plant.

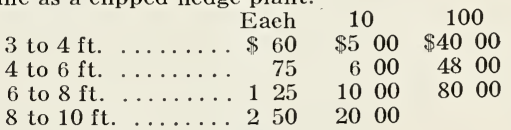

10 to $12 \mathrm{ft}$....... 400

CASTANEA pumila, Chinkapin. 3 to $25 \mathrm{ft}$. A fine shrub; abundant catkins of bright yellow or white flowers, followed by burs enclosing delicious nuts one third the size of ehestnuts. Suitable in the border and on dry and rocky slopes; a splendid ornamental, and valuable for fruit. Each 10 1 to $2 \mathrm{ft}$...... $\$ 80 \quad \$ 6 \_00$ 2 to $2 \mathrm{r} / 2 \mathrm{ft} . \ldots \ldots 100$

Catalpa speciosa, Western Catalpa. 50 to $100 \mathrm{ft}$.

Desirable ornamental; quiek growth; showy panicles of white flowers.

5 to $9 \mathrm{ft}$........\$ 75 to $\$ 200$ eaeh

CEPHALANTHUS oceidentalis, CoMmon ButTONBUSH. 3 to $12 \mathrm{ft}$. Good shrub for wet loeations. Each 10

1 to $2 \mathrm{ft}$. ...... \$ $35 \quad \$ 280$

CHIONANTHUS virginica, White FRINGE. 5 to $30 \mathrm{ft}$.

Spreading shrub; in early June a mass of fragrant, drooping, white flowers; followed by showy dark blue fruit.

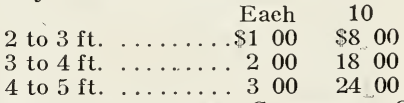

CLETHRA acuminata, CinNAMON-Clethra. 8 to $15 \mathrm{ft}$.

From the Carolina mountains; conspieuous red bark and drooping racemes of white

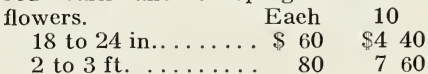

alnifolia, Sweet Clethra. 3 to $10 \mathrm{ft}$.

A mass of very fragrant white flowers in late summer when flowering shrubs are rare.

$$
\begin{array}{lrr}
18 \text { to } 24 \text { in. elumps } & \$ 65 & \$ 600 \\
2 \text { to } 3 \mathrm{ft} \text {. clumps ... } & 80 & 750
\end{array}
$$

tomentosa, Woolly Cilethra. 2 to $8 \mathrm{ft}$.

Similar to the Sweet Clethra and invaluable, as it flowers two or three weeks later.

9 to 12 in........ E \$ $50 \quad \$ 400$ 100 


\section{\begin{tabular}{llll}
\hline KELSEY'S HARDY AMERICAN PLANTS \\
\hline
\end{tabular}}

THE BEST HARDY AMERICAN AZALEAS

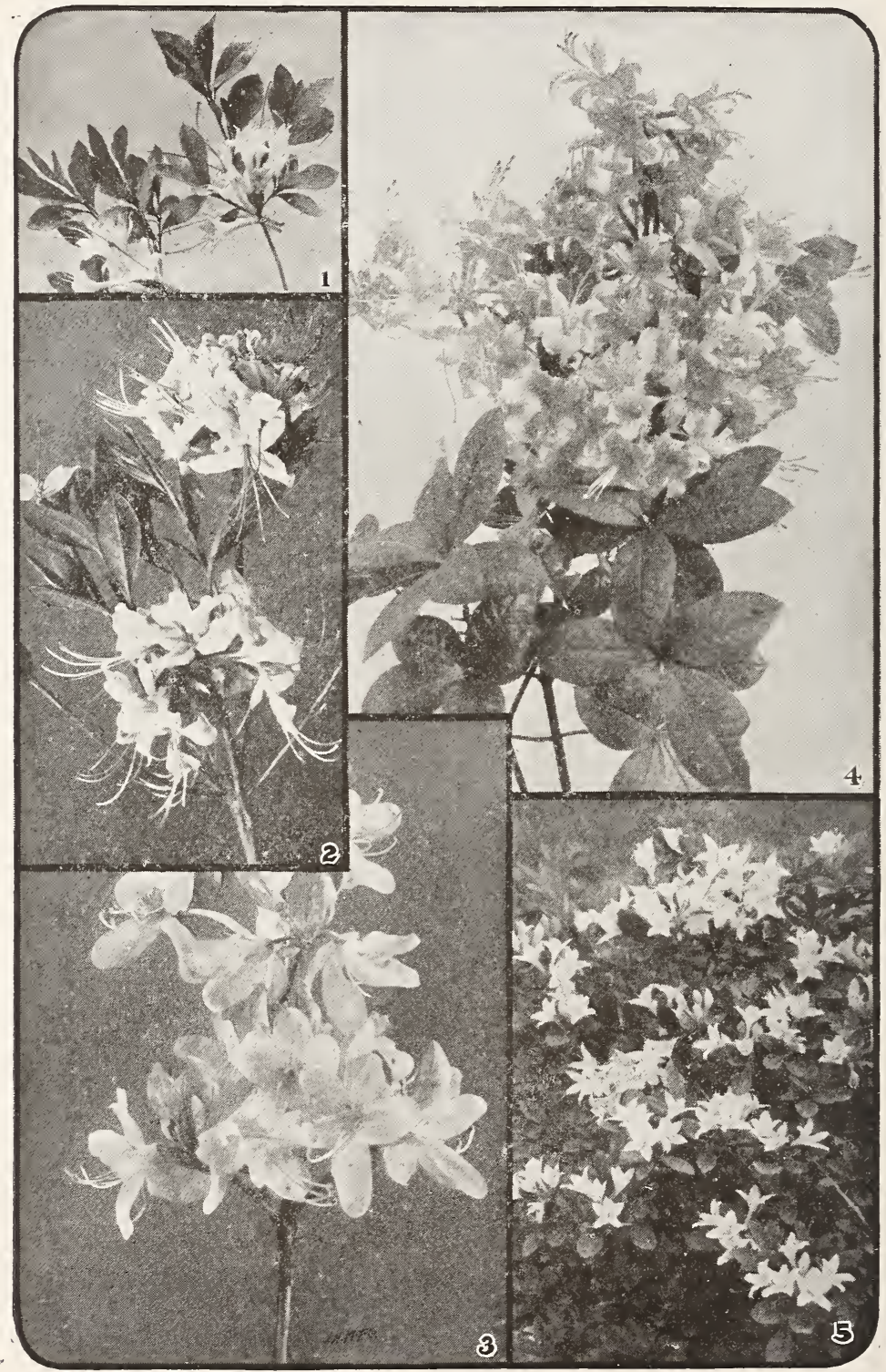

1. Azalea viscosa 2. Azalea nudiflora 3. Azalea vaseyi
4. Azalea lutea
5. Azalea arborescens 
CORNUS alternifolia, PAGODA DOGWOOD. 10 to $25 \mathrm{ft}$.

Very picturesque shrub or small tree, flat top and bushy. Horizontal branches are disposed in whorls representing each annual growth.

$$
\text { Each } 10
$$

3 to $4 \mathrm{ft}$. Seedlings . \$ $30 \quad \$ 250$

florida, Flowering Dogivood. 10 to $40 \mathrm{ft}$.

One of the most beautiful American flowering small trees.

$$
\begin{array}{rrr} 
& \text { Each } & 10 \\
3 \text { to } 4 \mathrm{ft} . & \ldots \ldots \ldots . \$ 25 & \\
4 \text { to } 6 \mathrm{ft} . & \ldots \ldots \ldots 200 & \$ 1800
\end{array}
$$

paniculata (racemosa), GRAY Dogwood, 6 to $15 \mathrm{ft}$.

Very handsome free flowering shrub with white fruit on red peduncles.

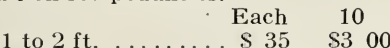

rugosa, Roundleaf Dogwood. 3 to $10 \mathrm{ft}$.

Spreading shrub with roundish leaves; light blue fruit.

$$
\begin{array}{rcc}
\text { Each } & 10 & 100 \\
12 \text { to } 18 \text { in....... } \$ 35 & \$ 300 & \$ 2400
\end{array}
$$

stolonifera, RED-OSIER Dogwood. 6 to $10 \mathrm{ft}$.

Dark blood-red branches; very spreading habit.

$$
\begin{array}{rrr}
18 \text { to } 24 \text { in....... } & \begin{array}{c}
\text { Each } \\
2 \text { to } 3 \mathrm{ft} . \ldots \ldots \ldots
\end{array} & \multicolumn{1}{c}{10} \\
240 & 60 & 500
\end{array}
$$

Hort. var. of Cornus.

Goldentwig Dogwood (stolonifera flaviramea; aитеa). 6 to $10 \mathrm{ft}$.

Golden yellow branches.

\begin{tabular}{|c|c|c|}
\hline & Each & 10 \\
\hline 3 to $4 \mathrm{ft}$. &.$\$ 225$ & $\$ 2000$ \\
\hline $5 \mathrm{ft}$. & & $\begin{array}{ll}30 & 00\end{array}$ \\
\hline & $\ldots \ldots \ldots 700$ & 6000 \\
\hline
\end{tabular}

$$
\begin{aligned}
& \text { Each } 10 \\
& 1 \text { to } 2 \mathrm{ft} \text {. ...... \$ } 45 \$ \$ 350 \\
& 2 \text { to } 3 \mathrm{ft} . \ldots \ldots \ldots .60 \quad 60 \quad 400
\end{aligned}
$$

RedFlowering Dogwood (florida rubra). 10 to $40 \mathrm{ft}$.

A splendid stock of this choice variety. The Dogwoods are invaluable for woods planting. The scarlet fruit in autumn and early winter is very showy and fine for bird tood.

4 to $7 \mathrm{ft}$. heavy specimens $\$ 6$ to 1800 each

CORYLUS rostrata, Beaked Hazelnut, 2 to $6 \mathrm{ft}$.

A splendid undershrub for woodlands and a good border plant.
2 to $3 \mathrm{ft}$.
Each
10
$\$ 400$

\begin{tabular}{|c|c|c|}
\hline & Each & 10 \\
\hline 12 &.$\$ 150$ & $\$ 1400$ \\
\hline & $\begin{array}{l}250 \\
350\end{array}$ & $\begin{array}{ll}24 & 00 \\
30 & 00\end{array}$ \\
\hline
\end{tabular}

COTONEASTER dielsiana. 4 to $6 \mathrm{ft}$.

A very desirable shrub, with spreading and arching branches and red fruit.

18 to 24 in....... Each $\$ 100$

2 to $3 \mathrm{ft} . \ldots \ldots \ldots 150 \quad 1200$

horizontalis (davidiana). 6 in. to $2 \mathrm{ft}$.

Low spreading shrub of extreme beauty when planted over boulders and among rocks. Glossy foliage; graceful habit; brilliant scarlet fruit.

integerrima. 3 to $4 \mathrm{ft}$.

A very good species with glossy foliage and scarlet fruit.

18 Each
2 to 24 in....... $2 \frac{1}{2} \mathrm{ft} . \ldots \ldots \% 300$

COTONEASTER lucida. 8 to $12 \mathrm{ft}$

Flowers in nodding corymbs, May, June. Fruit purplish-black.

6 to 12 in...... Each $\$ 100 \quad \$ 800$

CRATAEG US arkansana, ARKANSAS HAWTIIORN. 12 to $20 \mathrm{ft}$

Fruit bright crimson in late October.

$$
\text { Each } 10
$$

12 to 18 in. seedlings $\$ 50 \quad \$ 350$

arnoldiana, Arnold HAWTHORn, 12 to $20 \mathrm{ft}$.

One of the best of the Hawthorns, flowering in

May, with bright crimson truit in August.

12 to 18 in 10

$$
\$ 50 \$ 350
$$

crusgalli, Cockspur Thorn, 15 to $40 \mathrm{ft}$.

Decorative sort; distinct habit, leaves glossy green, turning brilliant scarlet in fall; red fruit persistent into winter.

$$
4 \text { to } 6 \mathrm{ft} . \ldots \ldots . \$ 125 \quad \$ 1000
$$

monogyna, ENGLIsH Hawthorn (One-stone).

15 to $20 \mathrm{ft}$

One of the best varieties of English Hawthorn.

$$
12 \text { to } 15 \text { in....... \& } \$ 60 \quad \$ 400
$$

nitida, Glossy Hawthorn. 20 to $30 \mathrm{ft}$.

Very ornamental with bright scarlet fruit, which persists into February.

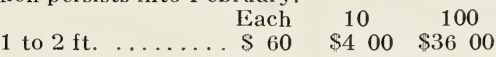
prunifolia, Plumleaf Thorn. 15 to $30 \mathrm{ft}$.

Red fruit; a fine variety.

$$
1 \text { to } 2 \mathrm{ft} \text {. seedlings } \quad \begin{array}{cc}
\text { Each } & 10 \\
\$ 60 & \$ 400
\end{array}
$$

punctata, DotTed HAwthoRN. 10 to $25 \mathrm{ft}$.

Dull red fruit in October falling soon. One of the finest for hedges and shrubberies, branches spreading horizontally.

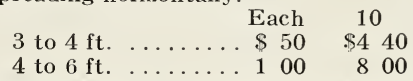

rotundifolia, Roundeaf Hawthorn. 10 to $20 \mathrm{ft}$.

Bright red fruit; usually a large shrub.

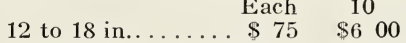

tomentosa, Pear Hawthorn. 12 to $20 \mathrm{ft}$.

Fruit yellow or yellowish red. Conspicuous.

$$
1 \text { to } 2 \mathrm{ft} \text {. seedlings } \begin{array}{cc}
\text { Fach } & 10 \\
\$ 60 & \$ 500
\end{array}
$$

DEUTZIA gracilis, SLender Deutzia, 2 to $3 \mathrm{ft}$

One of the best low forms. Pure white flowers. May and June.

$$
12 \text { to } 15 \text { in....... } \$ 50 \quad \$ 400
$$

scabra crenata, Scallop Deutzia. 4 to $6 \mathrm{ft}$.

Double white flowers tinged with pink.

$$
2 \text { to } 3 \mathrm{ft} . \ldots \ldots \ldots \text { Each } 10
$$

Hort. var. of Deutzia.

Lemoine D. (lemoinei). 3 to $4 \mathrm{ft}$.

One of the best Lemoine Hybrids, very vigorous and more showy flowers than D. gracilis.

$$
12 \text { to } 15 \text { in..... E } \$ 50 \quad \$ 400
$$

Pride of Rochester. 4 to $6 \mathrm{ft}$.

Very large flowers faintly tinged with rose outside. One of the best horticultural varieties.

2 to $21 / 2 \mathrm{ft} . \quad \ldots \ldots$ Each $\quad \begin{gathered}10 \\ \$ 50\end{gathered} \$ 400$

DIERVILLA rivularis, Georgia Bush-honeySUCKLE. 4 to $6 \mathrm{ft}$.

Yellow flowers, July, August; one of the best undershrubs.

2 to $3 \mathrm{ft} . \ldots \ldots \ldots$ Each $\quad \begin{gathered}10 \\ \$ 50\end{gathered} \$ 430$


DIER VILLA sessilifolia, SOUTHERN BUSHHONEYSUCKLE. 3 to $5 \mathrm{ft}$.

Sulphur-yellow flowers, very free bloomer in June, July. Makes a dense shrub.

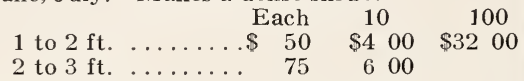

EUONYMUS alatus, Winged Euonymus. 6 to $10 \mathrm{ft}$.

One of the most conspicuous, with brilliant scarlet fruit and foliage turning crimson in autumn; branches stiff with corky wings.

\begin{tabular}{|c|c|c|}
\hline & Each & 10 \\
\hline 2 to 18 in.. & $\$ 7$ & $\$ 60$ \\
\hline beav & & 100 \\
\hline
\end{tabular}

bungeanus. 10 to $15 \mathrm{ft}$.

Slender branches; large scarlet fruits, hanging on till late.

$$
\begin{aligned}
& 2 \text { to } 3 \mathrm{ft} \quad \text { Each } 10 \\
& 3 \text { to } 4 \mathrm{ft} . \ldots \ldots \ldots 150 \quad \$ 1200
\end{aligned}
$$

europaeus, European Burning Bush. 10 to 15 $\mathrm{ft}$.

Bright scarlet fruit in greatest profusion.

$$
\begin{array}{llll}
2 & \text { to } 3 \mathrm{ft} . & \ldots \ldots \ldots & 60 \\
3 \text { to } 4 \mathrm{ft} . & \ldots \ldots \ldots & \$ \ldots & 80
\end{array}
$$

latifolius, Broadleaf BurningBush. 15 to $20 \mathrm{ft}$.

Large, handsome foliage and pendulous fruit.

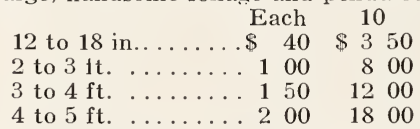

FAGUS americana, American Beech. 40 to $120 \mathrm{ft}$.

One of the best native trees for lawn or woods. Grows well in dense shade as an undershrub. The white or gray bark is most conspicuous.

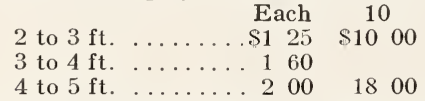

ylvatica, EUROPEAN BEECH. 80 to $100 \mathrm{ft}$.

Compact growing tree; very useful for hedges.

18 to 24 in . Each 10

FORSYTHIA intermedia, BORDER FORSYTHIA. 10 to $15 \mathrm{ft}$.

Floriferous; golden yellow.

$$
\begin{array}{rrr}
18 \text { to } 24 \text { in........ Each } & \multicolumn{1}{c}{10} \\
2 \text { to } 3 \mathrm{ft} . \ldots \ldots & 35 & \$ 300 \\
50 & 400
\end{array}
$$

Hort. var of Forsythia.

Fortune Forsythia (suspensa fortunei). 10 to $12 \mathrm{ft}$.

Dark-green foliage, arching branches, and golden yellow flowers with twisted petals.

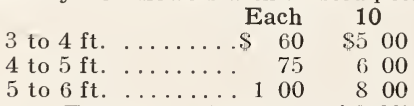

Siebold Forsythia (suspensa sieboldi). 8 to $12 \mathrm{ft}$.

Strong, thick-growing tvpe.

$$
\begin{array}{rrrr} 
& \multicolumn{2}{c}{\text { Each }} & \multicolumn{1}{c}{10} \\
2 / 2 \text { to } 3 \mathrm{ft} . & \ldots \ldots \ldots & 50 & \$ 400 \\
3 \text { to } 4 \mathrm{ft} . \ldots \ldots \ldots & 75 & 600
\end{array}
$$

GENISTA tinctoria, WOADWAXEN. 1 to $3 \mathrm{ft}$. This is the shrub that makes the Salem "pastures" a sheet of golden yellow in June. A fine undershrub for massing and rockwork.

$$
9 \text { to } 12 \text { in....... Each } \quad \begin{gathered}
10 \\
\$ 2
\end{gathered}
$$

HALESIA tetraptera monticola, MOUNTAIN Silverbell. 40 to $90 \mathrm{ft}$.

New variety, introduced by Highlands Nursery. Splendid pyramidal tree; a mass of silvery bell-like flowers in April and May.

$$
\begin{array}{r}
18 \text { to } 24 \text { in...... } \$ 100 \\
2 \text { to } 3 \mathrm{ft} . \ldots \ldots \ldots 150
\end{array}
$$

HAMAMELIS virginiana, Common WitchHAZEL. 10 to $25 \mathrm{ft}$.

Fine undershrub. Yellow flowers in late fall as the leaves are falling.

$$
2 \text { to } 3 \mathrm{ft} . \ldots \ldots \ldots \$ 35 \quad \$ 320
$$

HYDRANGEA arborescens, SMOOTH HydRaNGEA. 4 to $6 \mathrm{ft}$.

Fine for shady places.

$$
\begin{aligned}
& 6 \text { to } 12 \text { in Each } 10 \\
& 1 \text { to } 2 \mathrm{ft} \text {........ } 50 \quad 400
\end{aligned}
$$

quercifolia. OAKLEAF HYDRANGEA. 4 to $10 \mathrm{ft}$. Very conspicuous shrub, with tomentose branches and leaves.

$$
12 \text { to } 18 \text { in....... } \$ \text { Each } \quad 10 \quad \$ 600
$$

HYPERICUM aureum, GOLDEN ST. JOHNWORT. 2 to $4 \mathrm{ft}$.

An erect shrub with large. shining leaves. Flowers very large, 2 inches across, hright yellow with broad, conspicuous petals, their centers tufted with golden filaments. July to Áugust.

$$
1 \text { to } 2 \mathrm{ft} \text {....... } \text { Sach }^{35}
$$

densiflorum. 2 to $4 \mathrm{ft}$.

Flowers small. but in such profusion as to densely cover the plant with a mantle of yellow. July.

18 to 24 in....... $\$ \quad 40 \quad \$ 300 \quad \$ 2400$

2 to $3 \mathrm{ft} . \ldots \ldots \ldots .50 \% 50 \quad 50000$ prolificum, Shrubir St. Johnwort. 2 to $4 \mathrm{ft}$. The form growing on mountains is of elegant compact growth and valuable as a hedge plant. The foliage is dark green and abundant, as are the bright yellow blossoms which appear in July and continue till September.

$$
\begin{aligned}
& \text { Each } 10 \\
& 1 \text { to } 2 \mathrm{ft} . \ldots \ldots \ldots \text {..... } 40 \quad \$ 360 \\
& 2 \text { to } 3 \mathrm{ft} . \ldots \ldots \ldots 50 \quad 400
\end{aligned}
$$

ILEX monticola, Mountain Winterberry. 15 to $40 \mathrm{ft}$

Bright red fruit in profusion; largest of the deciduous Hollies.

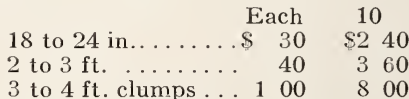

verticillata, CoMmoN WINTERRERRY. 6 to $15 \mathrm{ft}$

Perhaps the finest winter shrub, the scarlet fruits remaining on till late winter.

\begin{tabular}{lrr} 
& Each & \multicolumn{1}{c}{10} \\
12 to 18 in. clumps $\$$ & 45 & $\$ 4.00$ \\
18 to 24 in. clumps & 60 & 500 \\
2 to $3 \mathrm{ft}$. clumps... 100 & & 800
\end{tabular}

ITEA virginica, SweETSPIRE. 2 to $6 \mathrm{ft}$. Fine shrub for wet or dry locations; very fragrant flowers in June and July; leaves color brilliant bronzes in fall.

$$
12 \text { to } 15 \text { in....... Each } 35 \quad \$ 300
$$

JASMINUM nudiflorum, Winter Jasmine. 3 to $6 \mathrm{ft}$.

Very interesting drooping shrub, with yellow flowers, very early spring before leaves. 6 to 12 in........ \$ $50 \$ 400$ 


\section{KELSEY'S HARDY AMERICAN PLANTS}

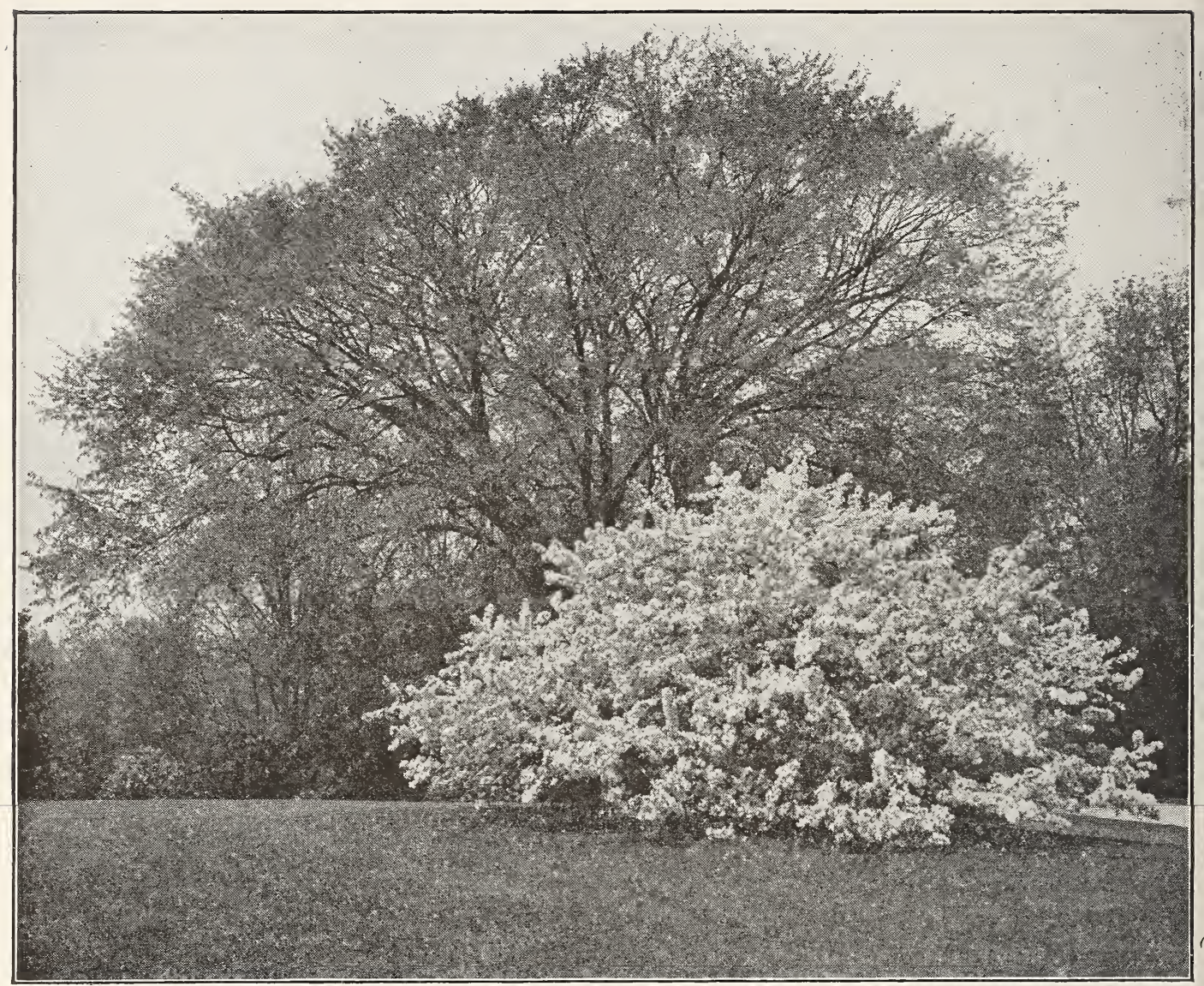

\section{Malus floribunda, Japanese Flowering Crab}

\section{THE FLOWERING CRABS}

\section{(Maluses)}

The Flowering Crabs have few rivals among gorgeous spring-flowering trees and shrubs. At the Arnold Arboretum one of the important events of the year is the blooming of the Crabs, followed by the showy fruit.

They are of easy culture, and whether planted singly or in masses, give remarkable and quick results. Not only are the Flowering Crabs beautiful on the small lawn, but they are used to greatest advantage on a large scale in woodland and other mass plantings. as are Dogwoods and Hawthorns. No group of plants have greater value for enlivening open forest parks and the country roadside. They present striking effects when planted on parking strips of boulevards and wide, city streets. 
MALUS parkmani, PARKMAN CRAB. 12 to $20 \mathrm{ft}$. A shapely small tree forming narrow vase-like head. Globose reddish fruit size of a small pea. Very fine rose-colored flowers on long slender stems.

\begin{tabular}{|c|c|c|}
\hline - $=5$ & Each & 10 \\
\hline 3 to $4 \mathrm{ft}$. & $\ldots \$ 100$ & $\$ 800$ \\
\hline 4 to $5 \mathrm{ft}$. & . 150 & 1250 \\
\hline $6 \mathrm{ft}$. . & $\ldots \ldots \ldots 200$ & 1800 \\
\hline
\end{tabular}

prunifolia rinki (ringo), ChInese APPLe. 15 to $18 \mathrm{ft}$.

Wide spreading, small tree with pinkish flowers and yellow fruit; quite juicy and edible.

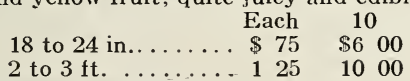

robusta. 20 to $40 \mathrm{ft}$.

This is the handsomest of white flowered Crabs and one of the most beautiful spring flowering trees. Fragrant, pure white flowers more than 1 inch in diameter; fruit dull red.

18 to 24 in........ $\$$. $\$ 75 \quad \$ 600$

$$
2 \text { to } 2 \frac{1}{2} \mathrm{ft} \text {. . . . . } 100
$$

sargenti, SARGENT CRAB.

Low shrub growing naturally on borders of salt marshes. Small flowers in crowded clusters; white or pale straw color flowers; bright scarlet fruit remains on branches till spring.

$$
\begin{aligned}
& \text { Each } 10 \\
& 6 \text { to } 12 \text { in........ \$ } 75 \text { \$6 } 00 \\
& 12 \text { to } 18 \text { in....... } 1201000
\end{aligned}
$$

scheideckeri, ScheIdECKER CRAB.

Small pyramidal tree; small pink flowers in greatest profusion. Should be in every collection.

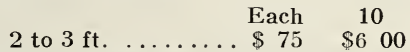

sieboldi calocarpa.

Large tree-like shrub and one of the handsomest of the Crabs. Large flowers and bright red lustrous fruit.

\begin{tabular}{rrrr} 
& Each & \multicolumn{1}{c}{10} \\
12 to 18 in........ $\$$. 60 & $\$ 500$ \\
18 to 24 in........ 100 & 800
\end{tabular}

spectabilis, Chinese Flowering Crab. 15 to $25 \mathrm{ft}$.

Tall Shrub or small tree, with erect, slightly spreading stems, large pink flowers, more or less double, and medium-sized yellow fruits.

$$
\begin{aligned}
& 2 \text { to } 3 \mathrm{ft} . \ldots \ldots \ldots . \$ 75 \quad \$ 600 \\
& 3 \text { to } 4 \mathrm{ft} . \ldots \ldots \ldots .100 \quad 800
\end{aligned}
$$

toringo, Toringo CraB.

Shrubby, small pink flowers, late.

$$
21 / 2 \text { to } 3 \mathrm{ft} . \quad \ldots \ldots . \$ 100 \quad \$ 800
$$

toringoides. 20 to $30 \mathrm{ft}$.

Small tree with gracefully drooping branches, white flowers and small pear-shaped red fruit.

18 to 24 in......\$1 00 each

zumi, Zumi Crab.

Pink and white flowers. Slender tree from elevated regions of Central Japan.

18 to 24 in.......\$1 00 each

Menziesia pilosa, Alleghany Menziesia. 2 to $6 \mathrm{ft}$.

Very fine ericaceous plant, with pink bells and bright red bark.

$\begin{array}{rrrr} & \text { Each } & 10 & 100 \\ 12 \text { to } 18 \text { in........ } \$ 60 & \$ 400 & \$ 3500\end{array}$

MYRICA carolinensis (cerifera), NORTHERN BAYBERRY. 2 to $8 \mathrm{ft}$.

The finest of ground-covers; dark glossy foliage and conspicuous white fruit in profusion, hanging till into spring.

$\begin{array}{rlcc}6 \text { to } 12 \text { in.......... } \$ 355 & \$ 280 & \$ 2200\end{array}$

gale, Sweetgale. 3 to $6 \mathrm{ft}$.

Clean shrub with fine foliage covered with catkins in early spring. Fine for borders of ponds.

$$
\begin{array}{rrrrr} 
& \text { Each } & 10 & \multicolumn{1}{c}{100} \\
12 \text { to } 18 \text { in........ } \$ 40 & \$ 320 & \$ 2800 \\
18 \text { to } 24 \text { in. clumps } & 80 & 700 & 6000
\end{array}
$$

OSTRYA virginiana, HOPHORNBEAM. 15 to $40 \mathrm{ft}$.

\begin{tabular}{|c|c|c|c|}
\hline & & & \\
\hline & & & \\
\hline 1 to $2 \mathrm{ft}$. & $\ldots \$ 40$ & $\$ 320$ & $\$ 3000$ \\
\hline 2 to $3 \mathrm{ft}$. & . 60 & 500 & 4000 \\
\hline $4 \mathrm{ft}$. & 80 & 720 & 6000 \\
\hline to $5 \mathrm{ft}$. & $\ldots 100$ & 800 & $70 \quad 00$ \\
\hline
\end{tabular}
Clean-growing tree, and fine for hedges.

$$
3 \text { to } 4 \mathrm{ft} . \ldots \ldots . . \$ 100 \quad \$ 800
$$

OXYDENDRUM arboreum, SOURWOOD. 15 to $60 \mathrm{ft}$.

This cannot be recommended too highly. New twigs are bright red and foliage colors brilliantly in autumn. Profusion of flowers resembling Lilies-of-the-valley in drooping racemes. Should be planted very freely.

4 to $5 \mathrm{ft} .100 \quad 800 \quad 7000$

PHELLODENDRON amurense. 30 to $50 \mathrm{ft}$. Annual branchlets orange-yellow or yellowish gray. A new tree of great value.

$$
9 \text { to } 12 \text { in........ \$50 } \$ 400
$$

sachalinense. 40 to $50 \mathrm{ft}$

The hardiest species and a splendid tree; showy black fruit in broad panicles.

$\begin{array}{rlrrr}1 & \text { Each } & 10 & 100 \\ 2 \text { to } 2 \mathrm{ft} . & \ldots \ldots \ldots & \$ 50 & \$ 400 & \$ 3000 \\ 3 \text { to } 4 \mathrm{ft} . & \ldots \ldots \ldots & 75 & 600 & \end{array}$

PHILADELPIUS coronarius (nivaiis), Swet

Mockorange: 6 to $10 \mathrm{ft}$.

Fragrant flowers, dense racemes, white or often light creamy tone. May and June.

$$
12 \text { to } 15 \text { in........ } \begin{gathered}
\text { Each } \\
\$ 60
\end{gathered} \$ 500
$$

cononarius grandiflorus, BIG SwEET MockORANGE. 8 to $12 \mathrm{ft}$.

Larger flowers than in the species.

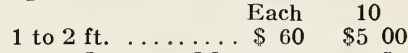

lemoinei, LemoIne Mockorange. 5 to $8 \mathrm{ft}$.

Tree flowering in dense racemes, having delicate but charming perfume.

$$
1 \text { to } 2 \mathrm{ft} \ldots \ldots \ldots . \$ \$^{\text {Each }} 60 \quad \$ 500
$$

PIERIS mariana, Staggerbush. 2 to $4 \mathrm{ft}$.

A dainty ericaceous plant with drooping white or pale pink flowers in May.

$$
\begin{array}{rrr}
\text { Each } & 10 & 100 \\
640 & \$ 300 & \$ 2000
\end{array}
$$

POPULUS simoni, Simon Poplar.

Rapid grower, useful as quick growing windbreak.

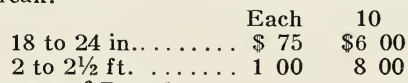

Hort. var. of Populus.

LOMBARDY POPLAR (nigra italica; fastigata). 40 to $60 \mathrm{ft}$.

Of great value for places where a columnar tree is needed; not long lived.

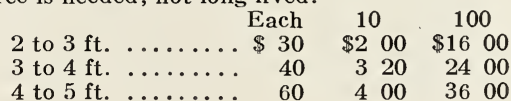


ROSA lucida, Lucida Rose. 2 to $4 \mathrm{ft}$. One of the best; bright pink; dense growth.

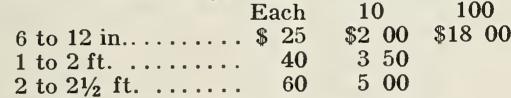

Iucida alba, White Lucida Rose. 2 to $4 \mathrm{ft}$. Very showy, pure white flowers and yellow stems.

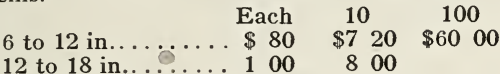

nitida, Bristly Rose. 2 to $6 \mathrm{ft}$.

Hairy stems; deep pink flowers.

$$
12 \text { to } 15 \text { in....... Each } \$ 35 \quad \$ 320
$$

rugosa (ferox), Rugosa Rose. 4 to $8 \mathrm{ft}$.

Well-known hedge plant; fine large fruit.

$$
\begin{array}{lrr}
6 \text { to } 12 \text { in ......... } & \begin{array}{r}
\text { Each } \\
\$ 25
\end{array} \quad \begin{array}{c}
10 \\
12 \text { to } 18 \text { in....... }
\end{array} \quad 40 & 320
\end{array}
$$

spinosissima, Scotch Rose. 3 to $8 \mathrm{ft}$.

Large white flowers, with mass of yellow stamens. One of the choicest of ornamentals.

\begin{tabular}{rrrr} 
& Each & \multicolumn{1}{c}{10} & \multicolumn{1}{c}{100} \\
12 to 18 in......... $\$ 60$ & $\$ 420$ & $\$ 4000$ \\
18 to 24 in........ & 80 & 600 & 5200
\end{tabular}

spinosissima altaica, Altal Rose. 4 to $8 \mathrm{ft}$.

More vigorous variety with large white flowers.

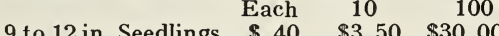

9 to 12 in. Seedlings $\$ 40 \quad \$ 350 \quad \$ 3000$

RUBUS laciniatus, CUTLEAF BlackBerRy. 6 to $12 \mathrm{ft}$.

Straggling bush or vine, beautiful white or blush flowers, black fruit.

$$
12 \text { to } 15 \text { in....... } \$ 40 \quad \$ 300
$$

odoratus, Flowering Raspberry. 3 to $6 \mathrm{ft}$. Large rose-purple flowers and red fruit; very large showy leaves. A fine undershrub and suitable for damp woods.

$$
18 \text { to } 24 \text { in....... } \begin{array}{r}
\text { Each } \\
\$ 35
\end{array} \quad \begin{aligned}
& 10 \\
& 20
\end{aligned}
$$

SALIX, Willow.

Our collection of Willows covers almost all the species that are planted in the Arnold Arboretum, and we have others in smaller quantities, that have lately been discovered in China and elsewhere. Many of the Willows are charming dwarf and semi-prostrate shrubs, notably beautiful, with bright yellow, brown, and green branchlets, or sometimes covered with a white bloom. The catkins are extremely showy and range from tiny balls of down to golden yellow.spikes. Most of them thrive both in dry soils or in very moist locations.

The Federal Horticultural Board has quarantined interstate shipments of all Willows and Poplars from this section claiming that the satin moth has been found and that it is a dangerous insect; so although our stock is clean we are not allowed to ship it excepting in this district, and my customers are deprived of buying some of the choicest of all new rare and beautiful ornamentals. It is more profitable to hunt bugs than to grow plants.

SAMBUCUS canadensis, American Elder. 6 to $12 \mathrm{ft}$.

One of our showiest native shrubs with white flowers in large flat-topped cymes; profuse black fruit in August and September.

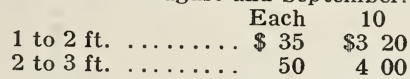

SORB US americana, American Mountaln-ASH. 15 to $30 \mathrm{ft}$.

Brilliant bright red fruit in big clusters.

$$
3 \text { to } 4 \mathrm{ft} \text {. ........\$1 } 00 \text { each }
$$

japonica (callosa). 2 to $4 \mathrm{ft}$.

Dwarf white form for low edgings.

$$
12 \text { to } 15 \text { in....... } \$ 50 \quad \$ 400
$$

thunbergi, ThUNBERg SPIRAEA. 3 to $4 \mathrm{ft}$.

Flowers cover the plant like a mantle of snow.

Each 10

anhouttei, VANHoutte SpIRaea. 5 to $6 \mathrm{ft}$.

Graceful shrub, with arching branches; one of the best.

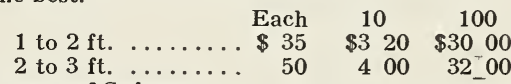

Hort. var. of Spiraea.

Anthony Waterer. 2 to $4 \mathrm{ft}$.

A good hedge plant, with dark reddish flowers.

Each 10

Billiard S. (billiardi). 4 to $6 \mathrm{ft}$.

Bright pink flowers. July and August.

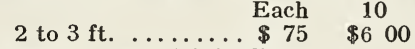

WhITE BILliard (billiardi alba).

White variety of preceding.

18 to 24 in....... Each $\$ 60 \quad \$ 500$

STEWARTIA pentagyna, Mountain Stewartia. 6 to $15 \mathrm{ft}$.

This, the so-called "American Camellia" is one of the most rare and beautiful of all North American shrubs. Erect, well-foliaged, and with large, axillary flowers, 3 to 4 inches across, with white creamy petals, deeply crenulated in the margins, resembling the single Camellia. June.

$$
\begin{aligned}
& 18 \text { to } 24 \text { in.......\$1 } 50 \quad \begin{array}{c}
\text { Each } \\
\$ 1250
\end{array} \\
& 2 \text { to } 2 \frac{1}{2} \mathrm{ft} . \ldots \ldots 200 \quad 1800
\end{aligned}
$$

SYMPHORICARPOS racemosus, COMMON SNOWBERRY. 3 to $5 \mathrm{ft}$.

A native with very showy, pure white fruit hanging in large clusters until late winter.

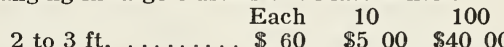
racemosus laevigatus, Garden SNowberRy. 4 to $6 \mathrm{ft}$.

Larger leaves and larger clusters of fruit than the preceding variety.

$$
18 \text { to } 24 \text { in...... Each } \$ 60 \quad \$ 50
$$

vulgaris, CORALBERRY. 2 to $5 \mathrm{ft}$.

The red or purplish fruit is produced in great profusion and hangs on till early spring.

$$
\begin{aligned}
& \text { Each } 10 \quad 100 \\
& 2 \text { to } 3 \mathrm{ft} \ldots \ldots \ldots \$ 60 \quad \$ 500 \quad \$ 4000 \\
& 3 \text { to } 4 \mathrm{ft} . \ldots \ldots \ldots \ldots \text {. } 75 \quad 600 \quad 5000
\end{aligned}
$$

SYRINGA japonica, J APANESE TREe Lilac. 20 to $30 \mathrm{ft}$.

Large clusters of creamy white flowers in June and July.

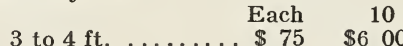

$$
\begin{aligned}
& 4 \text { to } 5 \mathrm{ft} . \ldots \ldots \ldots \ldots 100 \quad 800
\end{aligned}
$$$$
\text { persica, Persian Lilac. } 5 \text { to } 10 \mathrm{ft} \text {. }
$$

Flowers pale lilac. May or June.

$$
\text { Each } 10
$$

12 to 15 in........ \$ 30 \$2 50

vulgaris, CомMON LiLAC. 15 to $20 \mathrm{ft}$.

Blue or purple flowers in May.

$\begin{array}{rrrr} & \text { Each } & 10 & 100 \\ 2 \text { to } 3 \mathrm{ft} \text {. clumps ... } & \$ 80 & \$ 720 & \$ 6000 \\ 3 \text { to } 4 \mathrm{ft} \text {. clumps ... } & 125 & 1000 & 9000\end{array}$


SYRINGA vulgaris alba, Common White Lilac. 15 to $20 \mathrm{ft}$.

Does not "sucker" from the ground like vulgaris.

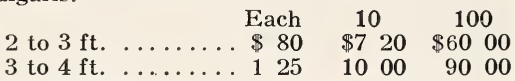

TILIA americana, AMERICAN LINDEN. 60 to 120 ft.

Large heart-shaped leaves, turning yellow in autumn; flowers creamy white. A grand tree for street or park.

\begin{tabular}{|c|c|}
\hline Each & 10 \\
\hline $\begin{array}{l}4 \text { to } 6 \mathrm{ft} . \ldots \ldots \ldots 75 \\
6 \text { to } 8 \mathrm{ft} .11 / 2 \text { to } 13 / 4 \text { in. }\end{array}$ & $\$ 600$ \\
\hline
\end{tabular}

8 to $12 \mathrm{ft}$. specimens $\$ 3$ to 700 each tomentosa, Silver LINDEN. 60 to $100 \mathrm{ft}$.

Very distinct shade tree of pyramidal form; leaves silvery underneath

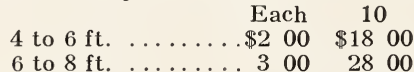

vulgaris (europaea), Common Linden. 60 to $120 \mathrm{ft}$.

A large handsome tree, valuable for street and lawns.

10 to $18 \mathrm{ft}$. specimens $\$ 10$ to 3500 each.

ULMUS americana, AMERICAN ELM. 60 to 120 ft.

One of our most stately trees for street, woods or lawn.

\begin{tabular}{|c|c|c|}
\hline Each & 10 & 100 \\
\hline to $8 \mathrm{ft} . \ldots \ldots \ldots \$ 100$ & $\$ 800$ & $\$ 7000$ \\
\hline 0 to $12 \mathrm{ft} .2$ to $2 \frac{1 / 2}{15}$ & 1200 & 100 \\
\hline cal. $\ldots \ldots \ldots 200$ & 1800 & 160 \\
\hline
\end{tabular}

12 to $14 \mathrm{ft} .2$ to $2 \frac{1}{2} 400 \quad 3600 \quad 34000$

VACCINIUM corymbosum, HrghBUSH BLUEBERRY. 4 to $12 \mathrm{ft}$

Without doubt one of our finest shrubs for border planting or with evergreens. Leaves turn crimson and claret in autumn. Fine clumps are offered.

\begin{tabular}{|c|c|c|}
\hline Each & 10 & 100 \\
\hline 12 to 18 in....... \$ 80 & $\$ 750$ & $\$ 6000$ \\
\hline o 24 in...... 100 & 800 & 7500 \\
\hline to $3 \mathrm{ft} . \ldots$ & 1200 & 10000 \\
\hline . 300 & 2800 & 24000 \\
\hline . . 400 & 3600 & 34000 \\
\hline
\end{tabular}

4 to $5 \mathrm{ft}$..... $400 \quad 3600 \quad 34000$ pallidum, Blueridge Blueberry. 2 to $6 \mathrm{ft}$. One of the choicest Blueberries from the Southern Alleghanies. A splendid border shrub, which has fruit of extra quality.

$$
\begin{aligned}
& 3 \text { to } 6 \text { in......... } \begin{array}{ccc}
\text { Each } & 10 & 100 \\
\$ 35 & \$ 300 & \$ 2800
\end{array} \\
& 18 \text { to } 24 \text { in......... } 75 \quad 600
\end{aligned}
$$

stamineum, DEERBERRY. 2 to $5 \mathrm{ft}$.

A splendid species, with drooping clusters of white flowers and large green and purple fruit.

$$
9 \text { to } 12 \text { in. ...... } \$ 40 \quad \$ 360
$$

VIBURNUM alnifolium (lantanoides), НоввLEBUSH. 3 to $10 \mathrm{ft}$.

Large showy flowers and clusters of black fruit.

Leaves large, conspicuous and color gorgeously in early fall thru shades of yellow to deep bronzes and reds.

$$
1 \text { to } 2 \mathrm{ft} . \ldots \ldots . \$^{\text {Each }} 75 \quad 10
$$

americanum, AMERICAN CRANBERRYBUSH. 8 to $12 \mathrm{ft}$.

Brilliant scarlet fruit, very persistent; finer variety than European Cranberrybush.

$$
1 \text { to } 2 \mathrm{ft} . \ldots \ldots \ldots . \$ 60 \quad \$ 500
$$

\begin{tabular}{|c|c|c|}
\hline & Each & 10 \\
\hline $\mathrm{ft}$. & $\ldots \ldots \$ 60$ & $\$ 500$ \\
\hline ft. & .. 80 & 720 \\
\hline$f t$ & $\ldots \ldots \ldots 125$ & 1000 \\
\hline
\end{tabular}

VIBURN UM cassinoides, WITHE-ROD, 6 to $15 \mathrm{ft}$. Upright, white flowers and pink fruit, changing to dark blue.

dentatum, Arrowwood. 4 to $10 \mathrm{ft}$.

Dense-growing; creamy white flowers in late spring; berries blue-black.

$\begin{array}{rrrr} & \text { Each } & 10 \\ 3 \text { to } 4 \mathrm{ft} \text {. clumps ... } & \$ 75 & \$ 600 \\ 4 \text { to } 5 \mathrm{ft} \text {. clumps . . } & 125 & 1000\end{array}$

VIBURNUM lantana, WAYFARING TREE. 10 to $15 \mathrm{ft}$. Red truit, changing to black.

1 to $2 \mathrm{ft} . \quad \ldots \ldots \ldots . \$ \begin{array}{ccc}\text { Each } & 10 & 100 \\ 275 & \$ 600 & \$ 5000\end{array}$

lentago, SheEpberry. 8 to $15 \mathrm{ft}$.

\begin{tabular}{|c|c|c|}
\hline & Each & 10 \\
\hline 1 to $2 \mathrm{ft}$. & $\ldots \$ 60$ & $\$ 500$ \\
\hline 2 to $3 \mathrm{ft}$. & . 100 & 800 \\
\hline 3 to $4 \mathrm{ft}$. & $\ldots 150$ & 1200 \\
\hline to $5 \mathrm{ft}$. & $\ldots 200$ & 1800 \\
\hline
\end{tabular}
Glossy black fruit

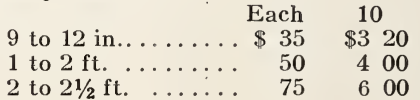

opulus, European CRANBERRYBush. 8 to $12 \mathrm{ft}$. Berries scarlet, persistent until into winter

opulus nanum, DWARF CRANBERRybush. 6 in. to $2 \mathrm{ft}$.

Dwarf, compact; suitable for rockeries or for edgings to beds; very hardy.

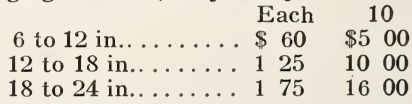

sieboldi, Siebold Viburnum. 6 to $10 \mathrm{ft}$.

White flowers, May or June; fruit changing from pink to bluish-black.

$\begin{array}{lll}\text { Each } & 10 \\ 18 \text { to } 24 \text { in....... } \$ 100 & \$ 800 \\ 2 \text { to } 3 \mathrm{ft} . \ldots \ldots & 40 & 1200\end{array}$

tomentosum, Japanese Doublefile ViburNUM. 6 to $12 \mathrm{ft}$

Large white flower-clusters; good foliage.

$$
\text { Each } 10
$$

3 to $4 \mathrm{ft} . \ldots \ldots . \$ \$ 125 \$ 1000$

WEIGELA amabilis, Rose WeIgeiA. 4 to $10 \mathrm{ft}$ Abundant flowers, changing from white or pale pink to carmine.

$$
\text { Each } 10
$$

ea, Pink Weigela. 4 to $8 \mathrm{ft}$.

Flowers pink or deep rose. May or June.

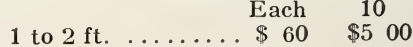

\begin{tabular}{|c|c|c|c|}
\hline & Each & 10 & 100 \\
\hline & . $\$ 35$ & $\$ 320$ & $\$ 3000$ \\
\hline hps & & 400 & 3200 \\
\hline to 24 in. clumps & & 720 & \\
\hline
\end{tabular}

ZANTHORHIZA apiifolia. YELLOWROOT. 1 to $4 \mathrm{ft}$. The finest American undershrub for planting under trees, along roadways, or where conditions of extreme moisture prevail. Finely cut green foliage which turns orange and yellow in autumn. Peculiar brown-purple flowers in pendulous racemes appear early 


\section{VINES, CREEPERS AND CLIMBERS}

\section{The sizes immediately following the names indicate the hights attained of the} Trees, Shrubs, and Plants in a wild state; under cultivation they usually reach and often exceed the lesser hight given.

AMPELOPSIS (Vitis) heterophylla, TRICOLJR

CREEPER.

Heartshaped leaves, deeply 3 to 5 lobed; very striking red, white and blue fruit.

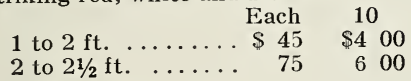

quinquefolia, Virginia CREeper.

Strong rambling vine with foliage coloring beautifully in autumn; does not cling well.

$$
2 \text { to } 3 \mathrm{ft} . \ldots \ldots \ldots \$ 50 \quad \$ 400
$$

quinquefolia engelmanni, Engelmann CREEPER.

This is the clinging form of the well-known Virginia Creeper. The leaves are much thinner and smaller than in the ordinary variety, the whole plant lacking the coarseness that characterizes A. quinquefolia, and it clings to walls like Ivy. The fall coloring is exceedingly brilliant and vastly superior to the common form, which is not used where the new variety is known and can be had.

$$
\begin{aligned}
& \text { Each } 10 \\
& 12 \text { to } 18 \text { in...... \$ } 40 \text { \$3 } 20
\end{aligned}
$$

tricuspidata (veilchii). JAPANESE CREEPER. Well-known vine for covering walls, etc., sometimes called Boston Ivy. Three-lobed leaves; shiny blue-black fruit.

$$
\begin{array}{lrr}
9 \text { to } 12 \text { in.......... } & \text { Each } & \multicolumn{1}{c}{10} \\
12 \text { to } 18 \text { in........ } & \$ 3 & 65 \\
4 & 500
\end{array}
$$

itacea, Thicket Creeper.

Dark green serrate leaves; fruit bluish black.

$$
15 \text { to } 18 \text { in....... } \begin{array}{cc}
\text { Each } & 10 \\
\$ 75 & \$ 6.00
\end{array}
$$

CELASTRUS orbiculatus punctatus, CHRISTmas Bittersweet.

Scarlet, showy fruit, hanging until into January. A splendid vine for walls, trees, etc.

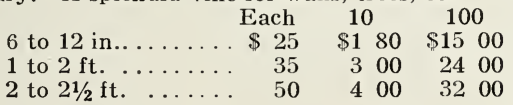

CLEMATIS crispa, Curly Clematis. 3 to $5 \mathrm{ft}$. Purple bell-shaped flowers. June to September.

$$
\text { Each } 10
$$$$
\$ 50 \quad \$ 400
$$

paniculata, Panicled Clematis. 15 to $30 \mathrm{ft}$. Vigorous climber; the white fragrant flowers cover the plant in late summer.

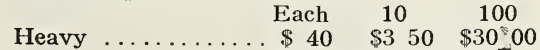

virginiana, Virginia Clematis. 10 to $20 \mathrm{ft}$. Native climber; hardy and graceful; white; fruit very showy. Each 10

$\$ 40 \quad \$ 350$

EUONYMUS obovatus, Running StrawberRyBUSH. 1 to $11 / 2 \mathrm{ft}$.

Fine ground cover, particularly for very shady places.

12 to 15 in....... $\begin{array}{cc}\text { Each } & 10 \\ \$ 50 & \$ 400\end{array}$

EUONYMUS radicans, WINTERCREEPER. 15 to $25 \mathrm{ft}$.

Shrubby vine, often reaching a hight of 20 feet; dark evergreen foliage. This takes the place of English Ivy in northern latitudes.

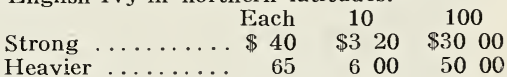

Hort. var. of E. radicans.

ROUNDLEAF WINTERCREEPER (radicans cartierei). Larger foliage than the type. often assuming the shape of a shrub.

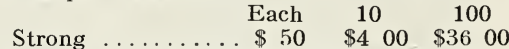

LARGELEAF WINTERCREEPER (radicans vegetus). Larger foliage, yellowish green a very fine variety.

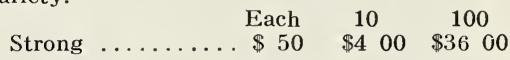

POLYGONUM baldschuanicum, SILVER

Fleecevine.

Rapid grower, covered with a sheet of white or pink-tinged flowers in long racemes.

18 to 24 in.......\$1 00 each

ROSA, Rose.

We can supply the leading varieties of climbing roses in strong plants.

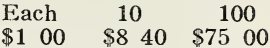

Dorothy Perkins, Light Pink.

Crimson Rambler, Crimson.

Excelsa, Crimson.

Pink Rambler, Pink.

Queen of the Prairie, Bright pink, striped white

Silver Moon, Silvery white, yellow center.

Yellow Rambler, Yellow.

Setigera, Single deep rose.

Tausendschon, Rosy carmine.

Tennessee Belle, Pink.

Veilchenblau, Reddish lilac.

White Perkins, White.

Wichuraiana, Pure White, in clusters,

and other standard varieties.

SCHIZOPHRAGMA hydrangeoides, JAPANESE

HYDRANGEAVINE.

Fine for tree trunks, walls, etc. Will cling to brick and stonework. Beautiful reddish bark. A remarkably fine shrub.

12 to 15 in.......\$1 50 each

VA CCINIUM vitis-idaea, CowBERRY.

Prostrate evergreen trailer, rarely over three inches in hight; very hardy and fine for rockwork and covering sandy spots.

$$
\text { Each } 10
$$

3 to 6 in........\$1 $00 \quad \$ 800$

WISTERIA multijuga (blue), LONGCluster

WISTERIA.

Japanese variety; light blue racemes 2 feet long. 18 to 24 in.......\$1 00 each

sinensis alba, White Chinese Wisteria One of the best old-fashioned sorts with flower clusters about six inches long.

18 to 24 in.......\$1 00 each 


\section{\begin{tabular}{lllll}
\hline$K E L S E Y^{\prime} S$ & $R A R D Y$ & $A M E R I C A N$ & $P \mathbb{L} A N T S$ \\
\hline
\end{tabular}}

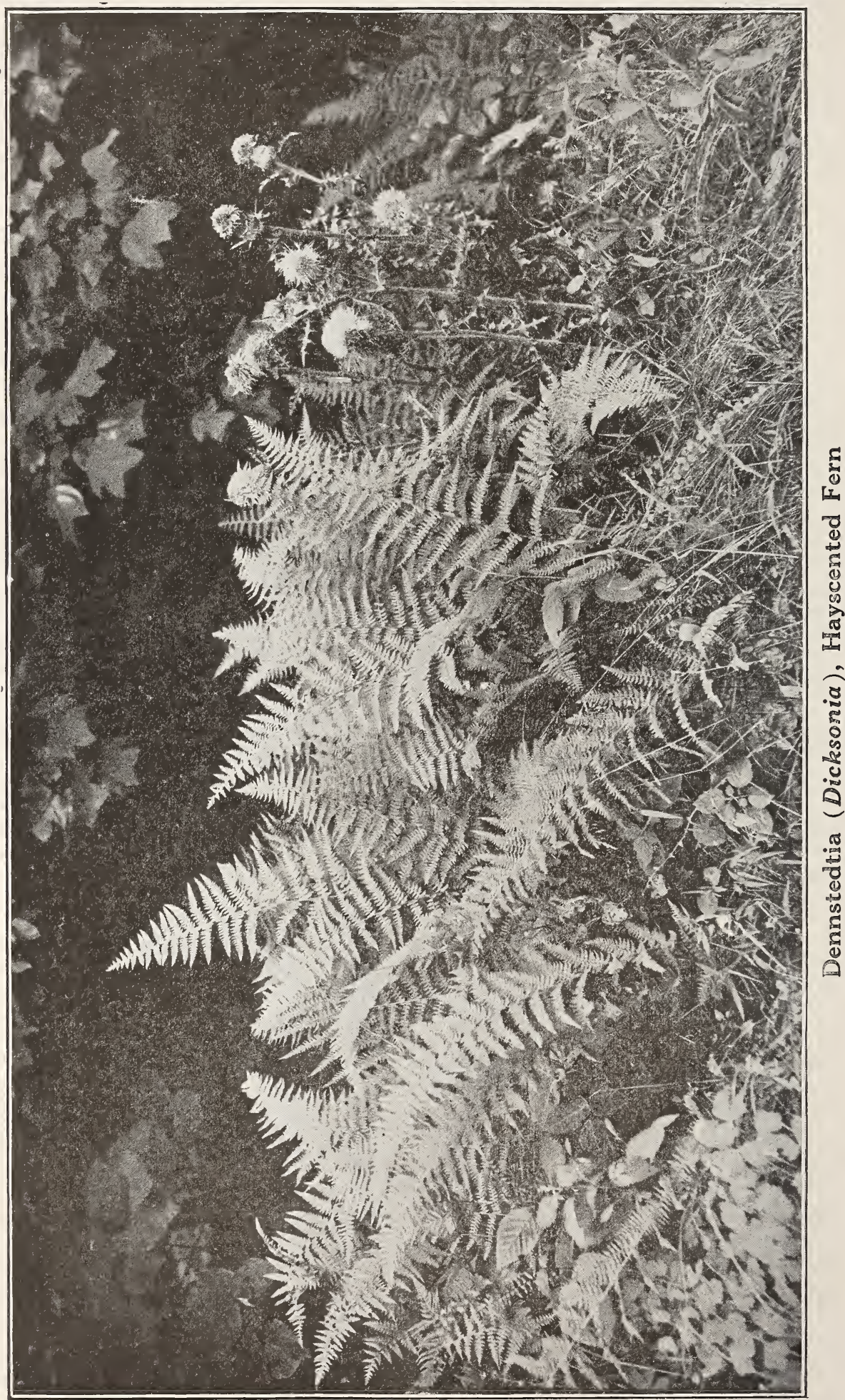


The sizes immediately following the names indicate the hights attained of the Trees, Shrubs, and Plants in a wild state; under cultivation they usually reach and often exceed the lesser hight given.

\section{Ferns}

Prices of Ferns unless otherwise noted: $\$ .25$ each; $\$ 2.10$ per $10 ; \$ 18.00$ per 100 .

ADIANTUM pedatum, American Maidenhair FERn. 8 to 20 in.

ASPLENIUM platyneuron (ebeneum), Eвony SPleEnwort. 9 to 18 in. $\$ .10$ each.

trichomanes, Maidenhair Spleenwort. 3 to 8 in.

ATHYRIUM (Asplenium), filixfemina, LADYFERN. 16 to 40 in.

CYSTOPTERIS bulbifera, BERRY BLADDERFERN. 12 to 24 in.

fragilis, BrittleFERN. 4 to 12 in.

DENNSTEDTIA (Dicksonia) punctilobula, HAYSCENTED FERN.

$$
20 \text { to } 40 \text { in....... Each } \quad \begin{array}{ccc}
10 & 100 \\
\$ 20 & \$ 180 & \$ 1600
\end{array}
$$

DRYOPTERIS cristata, CRESTED WOOdFERN.

$$
12 \text { to } 24 \text { in. }
$$

goldieana, Goldie Fern.

$$
24 \text { to } 40 \text { in....... Each } \quad \begin{gathered}
10 \\
\$ 40
\end{gathered} \$ 360
$$

(Aspidium) marginalis, LEATHER WOODFERN. noveboracensis, New YORK FERN. 12 in.

spinulosa, TOOTHED WOODFERN. 18 to 24 in. thelypteris, MARSHFERN. 12 to 18 in.

LYGODIUM palmatum, HARTFORD FERN.

Each 10

12 to 36 in....... \$50 \$4 50

POLYPODI UM vulgare, CoMmon Poly PODY. 3 to 6 in.

POLYSTICHUM (Dryopteris) acrostichoides, Christmas Fern. 24 to 36 in.

PTERETIS (Onoclea) nodulosa, OStrich Fern. 24 to 48 in.

ONOCLEA sensibilis, Sensitive Fern. 6 to 12 in.

OSM UNDA cinnamomea, Cinnamon Fern.

5. 32 to 60 in........ $\begin{array}{cccc}\text { Each } & 10 & 100 \\ \$ 40 & \$ 30 & \$ 32 & 00\end{array}$ rlaytoniana, Clayton Fern.

$\begin{array}{rrr}\text { Each } & 10 & 100\end{array}$ 24 to 36 in....... \$ $40 \quad \$ 360 \quad \$ 3200$ regalis, ROYALFERN.

12 to 16 in....... $\begin{array}{ccc}\text { Each } & 10 & 100 \\ \$ 40 & \$ 360 & \$ 3200\end{array}$

WOODSIA obtusa, Common Woodsia. 8 to 20 in.

\section{Hardy Herbaceous Perennials}

In this list will be found a collection of hardy herbaceous perennials that will give a good succession of bloom from early spring to late autumn. Nearly all are of easy culture. The usual list of herbaceous perennials offered in American catalogs can be secured and shipped with other orders, so that customers may feel safe in getting full collections.

Prices of herbaceous perennials unless otherwise noted: $\$ .30$ each; $\$ 2.40$ per $10 ; \$ 18.00$ per 100 .

ACTAEA rubra, Red Baneberry. Scarlet fruit.
Hardy Herbaceous Perennials (Continued)

ASTERS, in variety. 3 to $6 \mathrm{ft}$. White, blue, etc. Fall.

CALTHA palustris, Marshmarigold, 8 in. Yellow. April.

Chelone glabra (alba), White Turtlehead. 2 to $4 \mathrm{ft}$. White. June.

lyoni, Pink Turtlehead. 2 to $4 \mathrm{ft}$. Pink. June.

CHRYSANTHEM UMS, hardy. 2 to $4 \mathrm{ft}$. Fall. coreanum, KorEAN CHRYSANTHEMUM.

A new species from Korea introduced by Boxford-Highlands Nursery. Blooms very late, after first frosts; large white single flowers $11 / 2$ inches in diameter, turning to pink and purple shades. A remarkably fine low-growing plant to extend the flowering season almost into winter.

$$
\begin{array}{cc}
\text { Each } & 10 \\
\$ 75 & \$ 500
\end{array}
$$

Cimicif UGa racemosa, Cohosh Bugbane. 3 to $6 \mathrm{tt}$. White, July.

CONVALLARIA majalis, Lily-of-the-valley. 6 to 8 in. White. April to June.

CORNUS canadensis, BUnchBerRy. "Collected" clumps. 4 to 8 in. Flowers white; berries bright red. April, May.

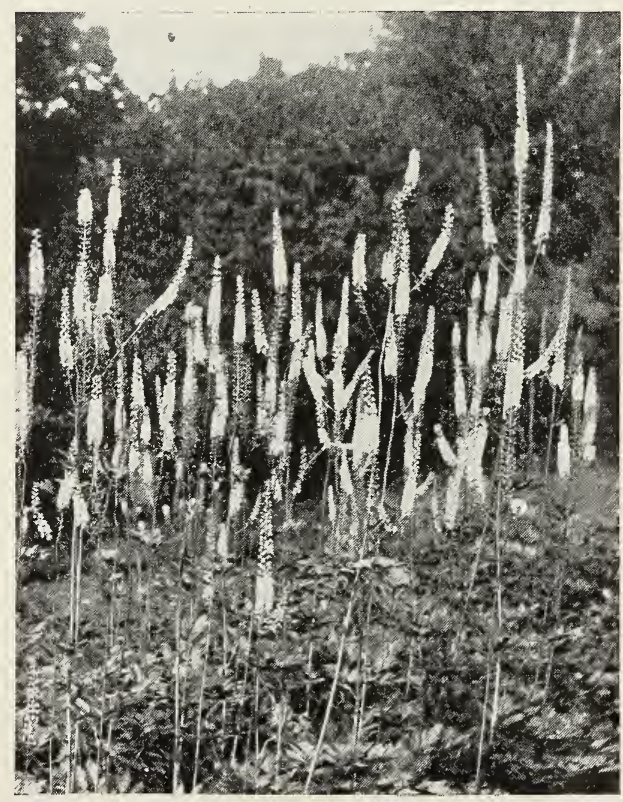

Cimicifuga racemosa. A charming perennial 
CYPRIPEDIUM acaule, Pink LAdyslipper. 6 to $12 \mathrm{in.} \mathrm{Lip} \mathrm{rose-purple,} \mathrm{rarely} \mathrm{white.} \mathrm{Large}$ pink-purple flowers with thick clusters of leaves. May and June.

californicum, California Ladyslipper. 1 to $2 \mathrm{ft}$. White with greenish sepals.

$$
\ldots \ldots \ldots \ldots . \$ \text { Each } \quad 10
$$

fasciculatum. 6 to 12 in.

Flowers greenish brown.

$$
\ldots \ldots \ldots \ldots \ldots+\$ 75 \quad \$ 600
$$

montanum. 1 to $2 \mathrm{ft}$.

A delicate species from the northwest. Flowers purple and white in June.

$$
\text { Each } 10
$$$$
\$ 75 \$ 600
$$

pubescens (hirsutum), CoMmon LADYSLIPPER. 1 to $2 \mathrm{ft}$.

Bright yellow flowers called slippers, sometimes three to five on each stem.

$$
\text { Each } 10
$$$$
\ldots \ldots \ldots \ldots \ldots \$ 50 \quad \$ 440
$$

reginae (spectabilis), SHowy LadysLIPPER. 1 to $2 \mathrm{ft}$.

The handsomest and one of the rarest of hardy Orchids. The broadly ovate sepals and petals are pure white, while the large inflated pouch is a beautiful soft red rose-color. A strong grower, preferring peat soils. Succeeds well in the Rhododendron bed or in the bog. June and early July.

Per crown ......\$ \$ 30 each

DICENTRA eximia, Fringe BleEdingheart. 12 to 18 in.

Pink; all summer.

spectabilis, Bleedingheart. $3 \mathrm{ft}$. Purple and

$$
\begin{aligned}
& \text { red. May. Each } 10 \\
& \$ 75 \$ 600
\end{aligned}
$$

DIONAEA muscipula, Venus Flytrap. 4 to 20 in. A most curious and rare insectivorous plant with extraordinary irritable leaves, furnished with sensitive hairs, which, when touched, induce the leaves to close forcibly, holding fast any venturesome insect. The small, white flowers are in clusters on the ends of stems 4 to 6 inches high. Very interesting for the winter sarden and to study. Pot in sandy loam or swamp moss, keeping moist, or plant outside with the Sarracenias and mulch heavily in winter.

DRosera rotundifolia, Roundeaf Sundew. 2 to 4 in. White. June.

GALAX aphylla, GalaX. A low ground-covering evergreen, with heart-shaped, crenate-toothed leaves of striking beauty, and white flowers borne on a graceful scape 12 to 18 inches high. The thick leaves turn brilliant shades of bronze, red, and crimson in autumn, remaining so through the winter. A remarkable ground-covering plant, particularly for use in the Rhododendron bed and shady banks.

GILlENIA (Porteranthus) stipulata, INDiAN Physic. 2 to $3 \mathrm{ft}$. Pink and white. July.

HABENARIA ciliaris, Yellow Fringe-Orchis. 12 to 18 in. Bright yellow. July.

HEMEROCALLIS, Gold Dust. 2 to $3 \mathrm{ft}$. Bronze-yellow. May, June.

dumortieri (sieboldi), EARLy DayliLy. $2 \mathrm{ft}$. Yellow and bronze. June.

fulva (disticha), OLD-FASHIONED DAyLily. Flowers orange. July, August. middendorfi, AMUR DAYlily. 2 to $3 \mathrm{ft}$. Golden yellow. June.

thunbergi, JAPANESE DAYLILY. 3 to $4 \mathrm{ft}$. Light yellow. June.
HEPATICA triloba (hepatica), Roundlobe HePatica. Scapes 4 to 6 in. Flowers earliest spring.

HOSTA (Funkia) lancifolia, Lanceleaf Daylily. 12 to 18 in. Light blue. July, August.

Hort. var. of Hosta. Big Common Daylily (plantagineagrandiflora). 12 to 18 in. White. August.

HYDRASTIS canadensis, GoldenSEAL. 4 to 12 in. White. May.

I RIS cristata, CREST IRIS. 3 to 6 in. Light blue. May.

germanica, GERMAN IRIS. Mixed varieties. 1 to $3 \mathrm{ft}$. May, June.

kaempferi, JAPANESE IRIS. 2 to $3 \mathrm{ft}$. Leaves 1 to $1 \frac{1 / 2}{\mathrm{ft}}$. Flowers blue, violet, etc., sometimes white, spreading 3 to 5 inches across. June to August.

pseudacorus, Common Yellow Iris. 3 to $4 \mathrm{ft}$. Bright yellow. May, June.

verna, Vernal Iris. 6 to 8 in. Blue. April, May.

versicolor (virginica), Common BLUe IRIS. 2 to $3 \mathrm{ft}$. Blue. May, June.

Hort. var. of Iris sibirica.

Snow QueEn, 12 to 18 in. White. May.

LAMIUM maculatum (album), SPotTed DEADNETTLE. Straggling or half trailing perennial. Flowers 1 inch long.

LIATRIS spicata, Spike Gayfeather. 2 to $3 \mathrm{ft}$. Rose-purple. September.

LILIUM canadense, Canada Lily. 2 to $5 \mathrm{ft}$. Yeilow or orange, usually spotted with brown. July. Loves deep, rich soil and shade, but stands open sun well.

carolinianum. Carolina Lily. 1 to $3 \mathrm{ft}$. Rare species of recurved type. Flowers orange, very fragrant, one to three on a stem. Stands dry conditions well.

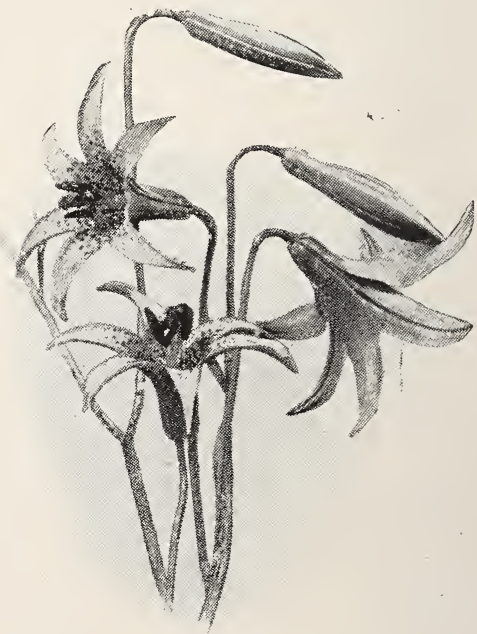

Lilium canadense 


\section{HA|R|LAN P. KELSEY, SALEM, MASSACHUSETTS}

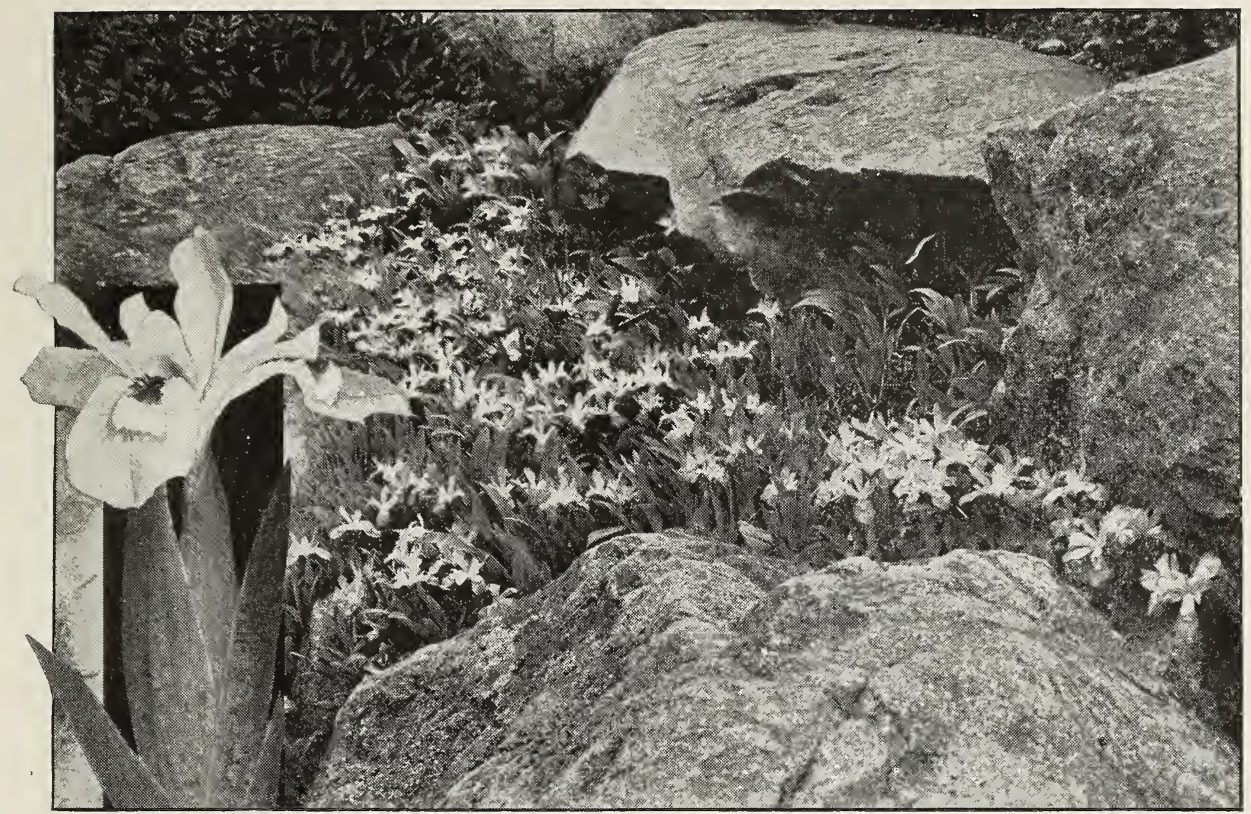

(Foto by H. P. K.)

\section{Iris cristata as}

LILIUM grayi, Grays Lily. $1 \frac{112}{2}$ to $3 \mathrm{ft}$. Introduced by me in 1888 , it has proved the leader in the bell-shaped type of hardy Lilies. Dark red-brown petals, beautifully spotted. Bulbs are never very large.

1st size . . . . . $\begin{array}{ccr}10 & 100 & 1000 \\ 25 & \$ 1000 & \$ 8000\end{array}$

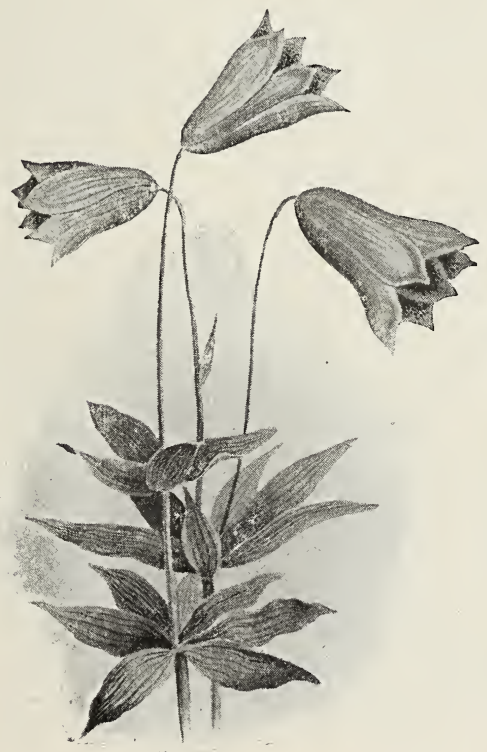

Lilium grayi a Rockery Plant

LILIUM superbum, American Turkscap LiLy. 3 to $6 \mathrm{ft}$. No description will do justice to this magnificent American Lily. Golden, recurved petals, flowering in perfect pyramids, of ten forty on a single stalk. A clump is literally a blaze of scarlet and gold.

$$
\begin{array}{cccr}
10 & 100 & 1000 \\
\text { lst size } & \$ 100 & \$ 800 & \$ 6000
\end{array}
$$

tigrinum, TIGER LILY.

Flowers bright salmon-red, spotted purplishblack, anthers red. August to September. One of the hardiest, most permanent and most easily grown of all Lilies. Very beautiful.

$$
\begin{array}{lll}
\text { Each } & 10 \quad 100
\end{array}
$$
$\begin{array}{llllll}\$ 0 & 40 & \$ 3 & 20 & \$ 28 & 00\end{array}$

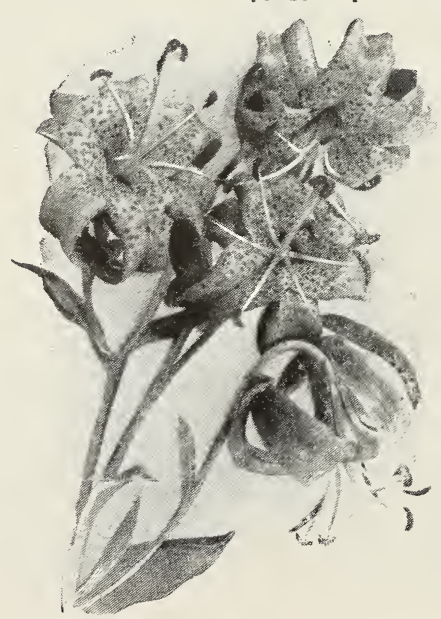

Lilium superbum. Tens of thousands annually. 


\section{$\overline{K E L S E Y ' S ~ H A R D Y ~ A M E R I C A N ~ P L A N T S ~}$}

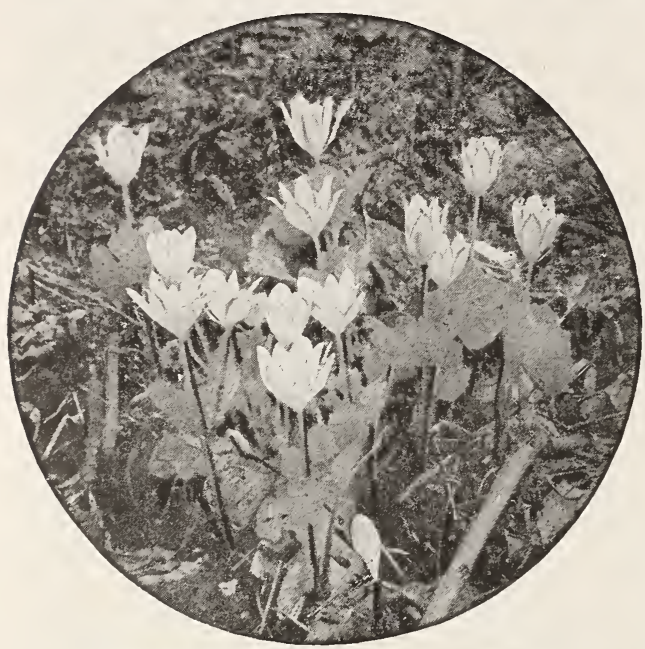

Bloodroot. One of our earliest Spring Flowers

LYSIMACHIA nummularia, MONEYWORT, 2 to 4 in. Bright yellow. June.

PAEONIA, PeONy, in variety. Spring and early $\begin{array}{llll}\text { summer. } & \text { Each } & 10 & 100\end{array}$ clumps . ...... $\$ 100 \quad \$ 860 \quad \$ 8000$

PHLOX subulata, Moss Phlox. 3 to 4 in. Pink and purple. April, May.

subulata alba, White Moss Phlox. 3 to 4 in. April, May.

PONTEDERIA cordata, Pickerelineed. 12 in. Violet-blue. July to September.

SANG UINARIA canadensis. Bloodroot. (Sanguinaria is shipped entirely at consignee's risk.)

SANG UISORBA canadensis, AMERICAN BURNET. 2 to $4 \mathrm{ft}$. White. September.

SARRACENIA drummondi, Drumiond PitchERPLANT. 10 to 32 in. Flowers greenish purple to deep purple. Each 10

$\ldots \ldots \ldots \ldots \ldots \$ 40 \$ \$ 36$

flava, Trumpet Pitcherplant. 10 to $34 \mathrm{in.}$ Flowers flavous yellow. Each 10

$$
\$ 40 \$ 360
$$

minor (variolaris), HoOded Pitcherplant.

8 to 24 in. Flowers with pale yellow petals.

$$
\text { Each } 10
$$

psittacina, Parrot Pitcherplant. 2 to 6 in. Flowers greenish purple to purple.

$$
\begin{array}{cc}
\text { Each } & 10 \\
\$ 40 & \$ 360
\end{array}
$$

purpurea, Common Pitcherplant. 2 to $10 \mathrm{in}$

Flowers greenish purple to purple.

$$
\begin{array}{cc}
\text { Each } & 10 \\
\$ 40 & \$ 360
\end{array}
$$

rubra, Sweet Pitcherplant. 6 to 20 in

Flowers crimson; scent of sweet violets.

$$
\begin{array}{cc}
\text { Each } & 10 \\
\$ 40 & \$ 360
\end{array}
$$

SEMPERVIVUM californicum. Rosettes 2 in. diameter; flowers pale red.

fimbriatum, Fringed Houseleek. 2 to $4 \mathrm{in}$. Rosettes 1 to $1 \frac{1 / 2}{2}$ in. diameter; flowers bright red.

globiferum, Globe Houseleek. Rosettes 11/2 to 3 in. diameter; flowers pale yellow.

tectorum (robustum), Roof Houseleek. $1 \mathrm{ft}$. Rosettes 3 to 4 in. diameter; flowers pale red.

SHOR'TIA galacifolia, OconeE-BELls. 6 to 8 in. The daintiest of rare plants, with clusters of large, wavy leaves, from which flower stems rise, bearing white or pink flowers, with crimpled petals in early April. Thrives best in Rhododendron" bed. Leaves colored rich bronze in fall.

$$
\begin{array}{cc}
\text { Each } & 10 \\
\$ 75 & \$ 600
\end{array}
$$

SOLIDAGO, in variety, GoldenRod. 1 to $5 \mathrm{ft}$, Yellow. Fall.

STENA NTHI UM, robustum, FeATHERFLEece. 3 to $5 \mathrm{ft}$. Tall, with extremely showy panicles often 2 feet long. The pure white flowers are borne on graceful compound panicles, often 2 to 3 feet long. A clump of these plants makes a show equaled by few herbaceous plants of any description. In northern latitudes it thrives best along stream or pond or in other moist locations.

STOKESIA laevis (cyanea), Stokesia. 1 to $2 \mathrm{ft}$. Blue. August to October.

THERMOPSIS caroliniana, CAROLINA ThERMopsis. 4 to $6 \mathrm{ft}$. Yellow. June, July.

TRILLIUM grandiflorum, SNOW TRILliUM. 8 to $18 \mathrm{in}$. The finest and largest species. Flowers 2 to 3 inches across; in April and May. One of our best early spring flowers; white turning rose color or marked with green.

$$
\begin{array}{rrrrr}
\text { Each } & 10 & 100 & 1000 \\
1 \text { st size } \ldots . . \$ \$ 20 & \$ 60 & \$ 500 & \$ 3500
\end{array}
$$

TYPHA latifolia, Common Cattail. 3 to $6 \mathrm{ft}$.

VIOLA cornuta, Tufted Pansy, in variety. Fine colors. May to August.

pedata. Birdefoot Violet. 3 to 5 in. Purple May to August.

Hort. var. of $\mathrm{V}$. pedata.

Pansy (bicslor), 3 to 5 in. Purple, two upper petals deep violet.

YUCCA flaccida, WEAKLEAF YUCCA. 3 to $5 \mathrm{ft}$. White. June, July.

$\begin{array}{rc}\text { Each } & 10 \\ \text { clumps } & \ldots \ldots \ldots . \$ 100\end{array} \$ 800$

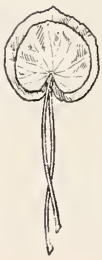

HARLAN P. KELSEY, Owner, SALEM, MASSACHUSETTS BOXFORD - HIGHLANDS NURSERY

EAST BOXFORD, MASS. 
$\overline{\text { HARLAN P. KELSEY, SALEM, MASSACHUSETTS }}$

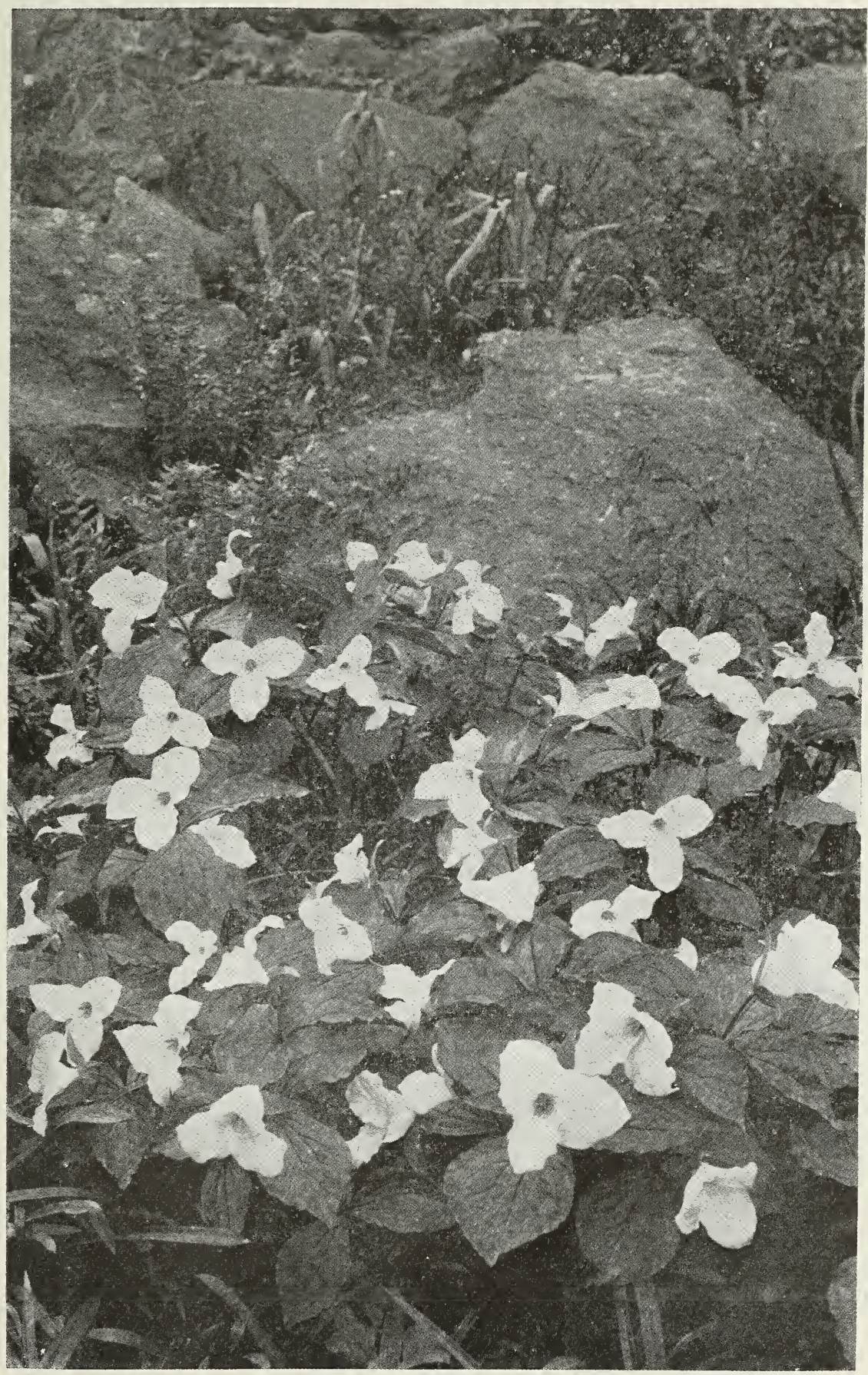

Trillium grandiflorum 


\section{KELSEY'S HARDY AMERICAN PLANTS}

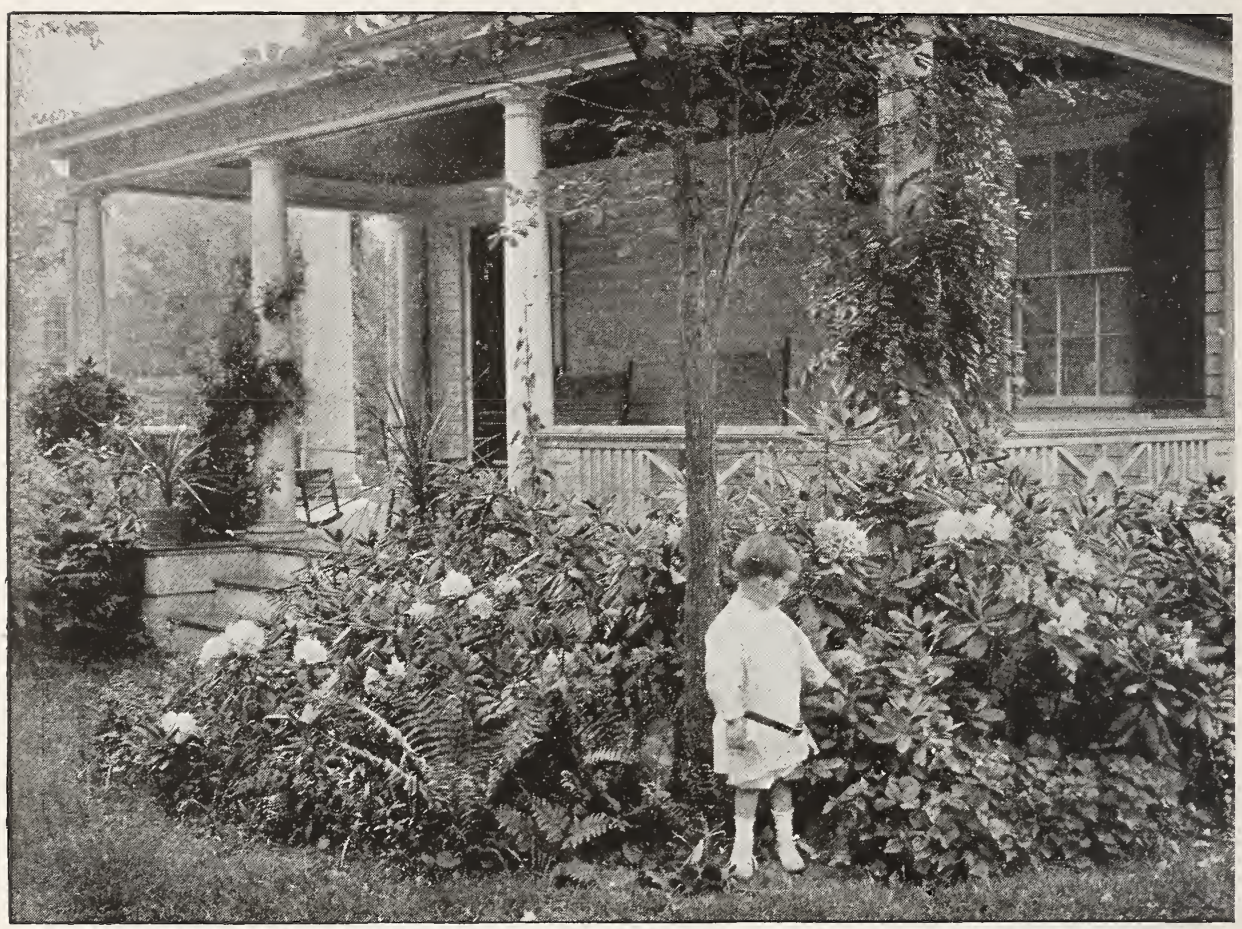

Rhododendron catawbiense massed around colonial building in Salem, Mass. Low ferns and evergreens for edgings. Planted by Harlan P. Kelsey

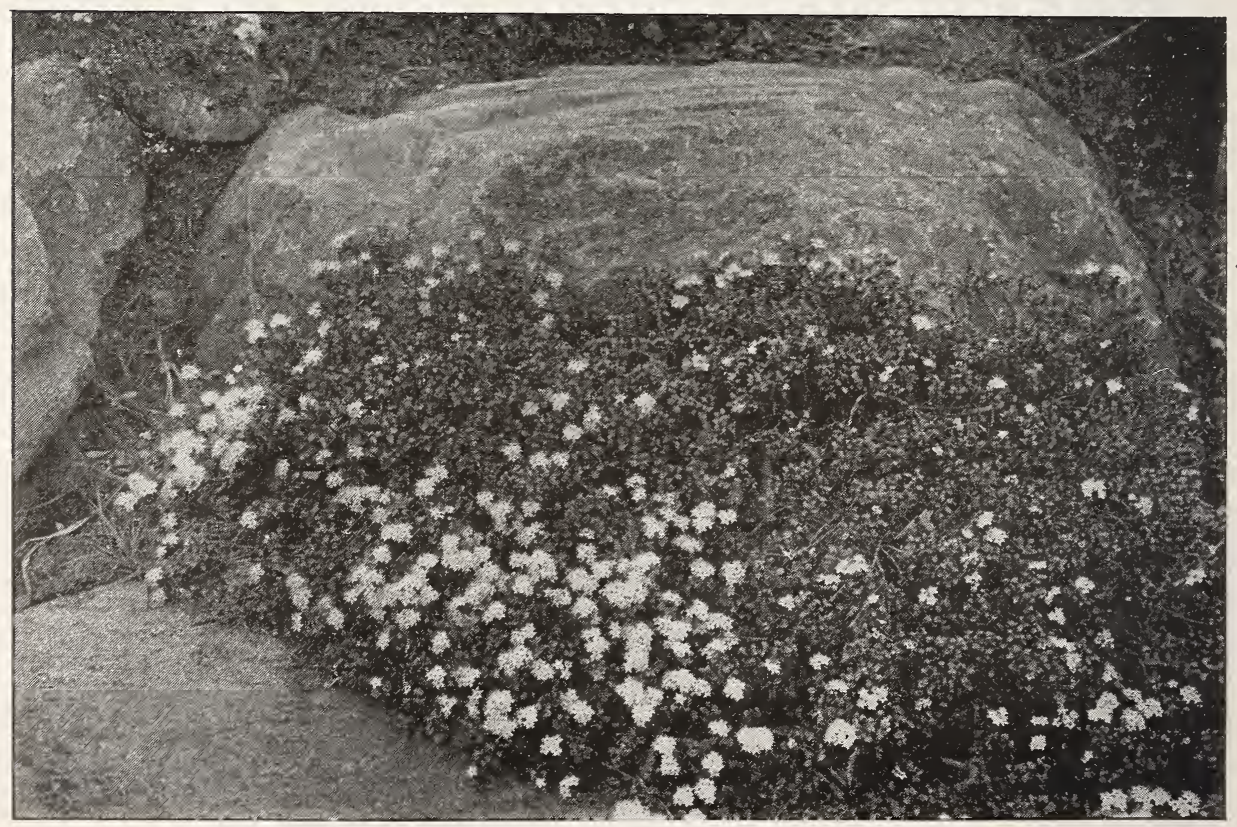

Leiophyllum prostratum as a rockery plant in Massachusetts 


\title{
THE SUCCESSFUL RHODODENDRON BED
}

\author{
By Harlan P. Kelsey
}

This includes Rhododendrons, Kalmias, Azaleas, Leucothoes, Blueberries and other ericaceous genera, and similar native and exotic plants and often such "fillers" as Ferns, Lilies, etc., most of which delight in acid soil conditions, and which are usually grouped together to make what is termed the "Rhododendron Bed."

This class of plants is most at home in somewhat shady and damp situations, and in a porous soil supplying plenty of humus and always showing more or less acid reaction. Limestone (alkaline) soils must be avoided, as a majority of ericaceous plants (Rhododendrons, Azaleas, Blueberries, etc.) are rarely if ever found growing naturally under such soil conditions. Sandy loam is favorable, but in all cases continuous supply of humus should be provided.

Mulching. This means that the Rhododendron bed should have annually a heavy mulch of hardwood leaves, which is left on the year round to decay. Mulching also keeps the ground cool in summer and warm in winter and protects the fine feeding rootlets of the plants. Removing the mulching in spring to make the beds "look better" is one of the greatest causes of non-success in growing Rhododendrons and similar plants. No expert gardener would ever think of so doing.

Preparation of Bed. Unless conditions are naturally favorable, excavate 2 to 3 feet and fill with woods mold, "Kalmia peat," good loam, rotted field-sods, and perhaps a third in bulk of swamp muck or peat, or similar soils. Make a tenth part of the mixture sharp sand, especially where the soil is too clayey. The center of the bed or plantation may be raised 6 to 12 inches above surrounding ground, after allowing for natural settling.

Planting. Plant the same depth as before (shown by earth line, or "collar" on stem) and firmly press soil around roots with the foot, but don't pack the earth too solid Rhododendrons are not telegraph poles. "Fillers," including Lilies and other bulbs and smaller ground-covering species, should be planted after the larger plants are all in and properly spaced. Then soak the ground and apply the mulching.

Winter Protection. If convenient, protect them with pine or other evergreen boughs, particularly where exposed to the sun and wind; yet Rhododendrons rarely suffer in the latitude of Boston or Buffalo, if properly planted and mulched. In the latitude of Ottawa and Quebec, Canada, a board fencing may be placed around the edge of the bed and much heavier temporary mulching of straw, etc., filled in almost or quite to the tops of the plants. It is rarely necessary to build a board cover, except on southern exposures to prevent sunburn, or with tender varieties not suitable for general planting, and even then evergreen boughs are preferable. Good ventilation must be provided.

Selecting the Location. For the Rhododendron bed, a northern exposure is preferable, especially in low elevation in the South, or elsewhere where freezing and thawing is quite continual. A direct winter sun on the frozen leaves of any broadleaf evergreen often kills outright or spoils the foliage. The north side of the building, wall, woods or hill is always preferable, and windswept locations should be avoided, unless proper measures are taken to check the heavy winds.

In Limestone Soils. Excavation is imperative and fresh soil showing acid reaction substituted. This can be successfully done. A striking example is shown in Highland Park, Rochester, New York, where one of the most beautiful Rhododendron and Azalea beds in America has been constructed and planted in a location originally of a heavy limestone nature. Blueberry culture is not a success in limestone soils.

Enemies of the Rhododendron. Rhododendrons, Kalmias and similar plants have few enemies. The only serious one I know is the Lace-wing Fly, which is native from New England throughout the Alleghanies, and is found on Kalmia angustifolia, Rhododendron maximum, Kalmia latifolia and occasionally on almost any broadleaf evergreen or deciduous tree or shrub. This pest appears in early spring on the under side of the leaves and gets its sustenance by sucking the sap. The leaves turn brown, giving the plant a ragged, unkempt appearance. It is easily disposed of by spraying the under side of the leaves, using a very fine nozzle, with an emulsion of ten gallons of whaleoil soap to one hundred gallons of water. While the Lace-wing Fly is more at home on Rhododendron maximum, it does not hesitate to attack all other species to a greater or less extent. Plants in the shade are rarely infested to any great degree.

The Use of "Fillers." For the best landscape effects, as well as providing a continual succession of bloom throughout the season, and actually protecting the Rhododendrons and supplying "feathered" edge to the ground, a large variety of shrubs and plants may be employed with the finest results. In fact, the planting of Rhododendrons without the use of "filler" or "edging" plants may give harsh, formal effects, which are neither desirable nor natural in any way. In the use of "fillers" great care must be taken as to 
time of blooming and color eflects, so they do not clash. It is surprising how many "filler" plants can be used without detracting from the broad evergreen eflect, and yet supplying an amazing amount of interesting detail and a continuous show of blossoms against a beautusul Rhododendron leaf background.

Some of the Best "Fillers" and "Edging" Plants. Andromeda polifolia, Chamaedaphne calyculata (Leatherleaf), Leiophyllum buxifolium, L. prostratum, Ilex glabra (Inkberry), Leucothoe catesbae1, Pieris floribunda, Taxus canadensis (Canada Yew), Galax aphylla, Gaultheria procumbens, Houstonia (Bluets), Mitchella repens

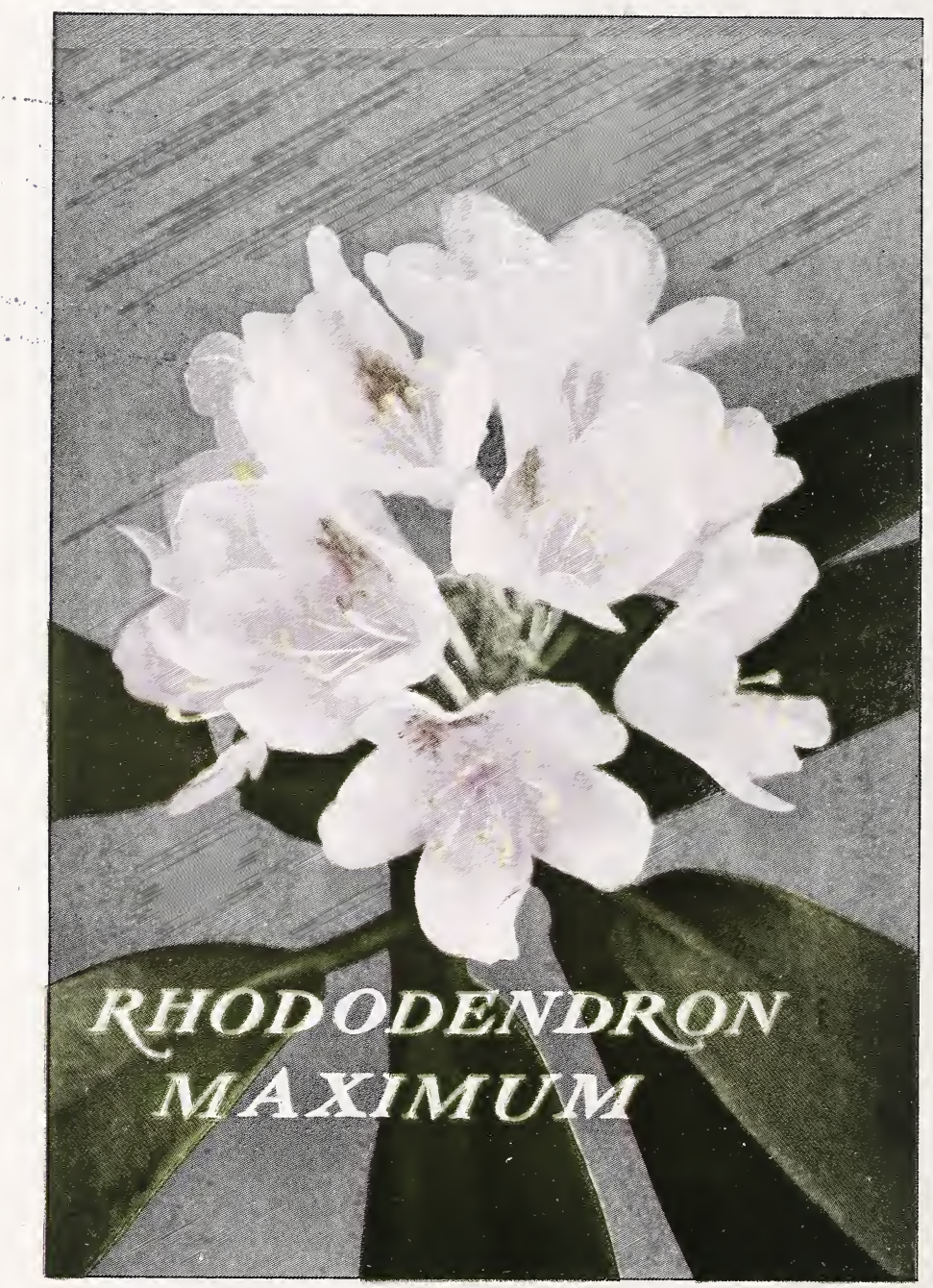

(Partridgeberry), Shortia galacifolia (Oconee-bells), Vinca minor (Periwinkle), Zanthorhiza apiifolia (Yellowroot), Lilies, Trilliums, Erythroniums (Dogtooth Violets), Ferns in great variety, Violets, Dicentra eximea (Fern Bleedingheart), Iris in great variety, particularly pseudacorus and Japanese; Azaleas in variety; Ilex verticillata, Aronias (Chokeberry) in variety and many other "berry-bearing" shrubs.

Jonquils and other spring bulbs may be used freely in the borders of plantations with charming results. 